UNIVERSIDADE DE SÃO PAULO

FACULDADE DE EDUCAÇÃO

PROGRAMA DE PÓS-GRADUAÇÃO EM EDUCAÇÃO

FERNANDO GOMES DE OLIVEIRA TAVARES

Práticas educacionais inovadoras e costumeiras: fatores de diferenciação 
FERNANDO GOMES DE OLIVEIRA TAVARES

\section{Práticas educacionais inovadoras e costumeiras: fatores de diferenciação}

\section{Versão original}

Dissertação apresentada ao Programa de Pós-Graduação em Educação da Faculdade de Educação da Universidade de São Paulo para obtenção do título de Mestre em Educação.

Área de concentração:

Educação e Ciências Sociais: desigualdades e diferenças

Orientador: Prof. Dr. Elie Ghanem

São Paulo 
Autorizo a reprodução e divulgação total ou parcial deste trabalho, por qualquer meio convencional ou eletrônico, para fins de estudo e pesquisa, desde que citada a fonte.

Catalogação da Publicação

Ficha elaborada pelo Sistema de Geração Automática a partir de dados fornecidos pelo(a) autor(a) Bibliotecária da FE/USP: Nicolly Soares Leite - CRB-8/8204

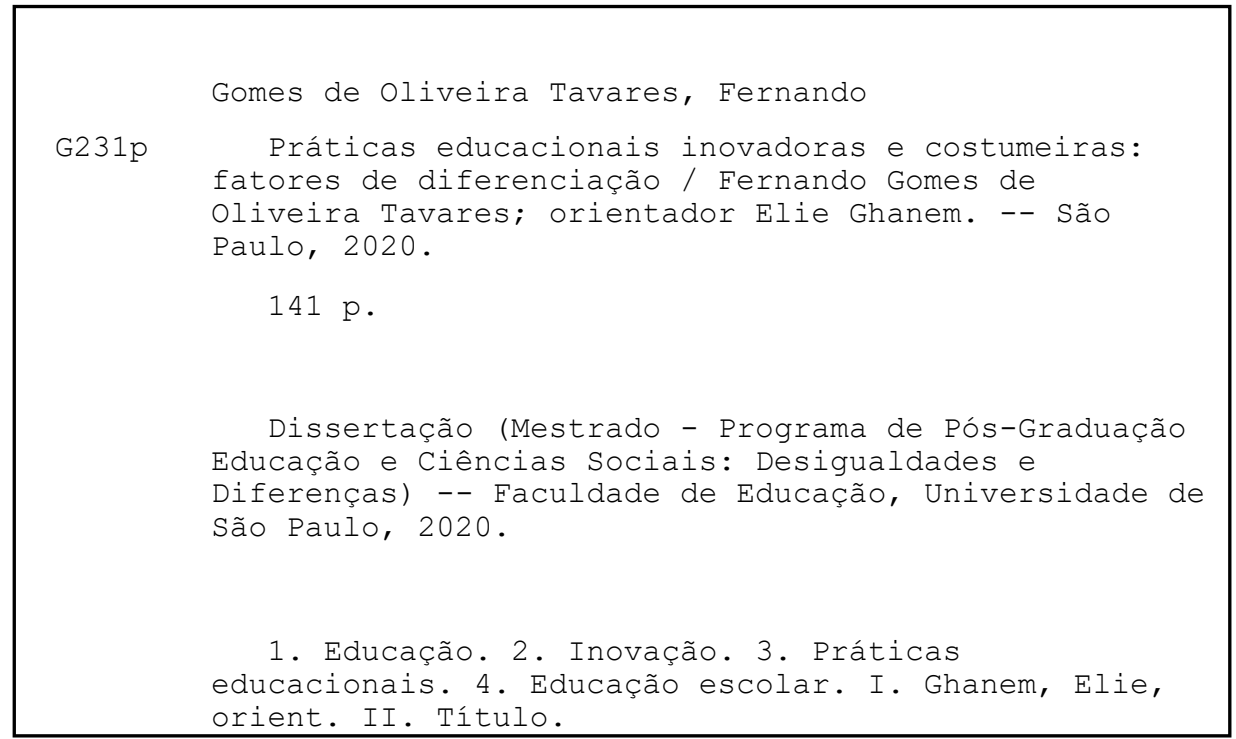


Nome: TAVARES, Fernando Gomes de Oliveira

Título: Práticas educacionais inovadoras e costumeiras: fatores de diferenciação

Dissertação apresentada ao Programa de Pós-Graduação em Educação da Faculdade de Educação da Universidade de São Paulo para obtenção do título de Mestre em Educação.

Aprovado em:

Banca examinadora

Prof. Dr.

Instituição:

Julgamento:

Assinatura:

Prof. Dr.

Instituição:

Julgamento:

Assinatura:

Prof. Dr.

Instituição:

Julgamento:

Assinatura: 
Dedico este trabalho aos interessados em mudar a realidade da educação escolar e peço que esqueçam o caminho do sujeito que sozinho faz acontecer. A mudança é um trabalho que se constrói coletivamente. 


\section{AGRADECIMENTOS ${ }^{1}$}

Dizem que a gratidão é o mais nobre dos sentimentos. Penso o contrário, que a gratidão é o mais plebeu dos sentimentos, pois ela está acessível para todos que desejam utilizá-la. Basta ter interesse e boa memória para não esquecer os privilégios recebidos.

Primeiramente, agradeço a meu amigo e orientador Prof. Dr. Elie Ghanem, que me orientou pelas estradas difíceis do mundo acadêmico e me fez enxergar o trabalho científico com mais leveza e responsabilidade.

Agradeço a todos os educadores que participaram da minha formação intelectual e que me ofereceram as condições necessárias para que eu pudesse enfrentar minhas próprias ignorâncias. Em especial à minha primeira orientadora na Universidade de São Paulo: a Profa . $\operatorname{Dr}^{\mathrm{a}}$. Valéria de Marcos.

Agradeço aos educandos, educadores e pais que fazem parte da Escola Projeto Âncora por me receberem de braços abertos e me aguentarem, durante meses, fazendo todos os tipos de perguntas possíveis.

Agradeço a grande parte dos meus amigos que, mesmo não tendo a mínima noção do que se faz em uma universidade (reflexo da nossa sociedade excludente), continuam me incentivando a prosseguir na carreira acadêmica.

Agradeço também pelo estímulo dos poucos amigos universitários que acreditam que a carreira acadêmica promove uma ascensão social imediata. Não compactuo com essa crença, mas as palavras de bom ânimo sempre serão bem acolhidas.

Agradeço profundamente aos meus pais, Assis e Luciene, por terem me concedido a vida e pelo apoio incondicional de sempre.

1 O presente trabalho foi realizado com apoio da Coordenação de Aperfeiçoamento de Pessoal de Nível Superior (Capes), código de financiamento 001. 
Agradeço à inteligência suprema e causa primária de todas as coisas que muitos costumam chamar de Deus. Não tenho a menor ideia do que se trata e não tenho a mínima pretensão de querer explicar o inexplicável. Todavia, assumo minha ignorância e me contento com o que sinto.

Por fim, mas não menos importante, sou extremamente grato a minha esposa Luana. Sem ela, não seria possível. Suas sugestões, sua paciência e, principalmente, seu apoio psicológico foram cruciais para a produção deste trabalho. 
"Mantenho que a meta da existência é encontrar felicidade, o que significa encontrar interesse. A educação deveria ser uma preparação para a vida. Nossa cultura não tem tido grande sucesso. Nossa educação, nossa política, nossa economia, levam à guerra. Nossa medicina não põe fim às moléstias. Nossa religião não aboliu a usura, o roubo. Nosso decantado humanitarismo ainda permite que a opinião pública aprove o esporte bárbaro que é a caça. Os progressos da época são progressos da mecânica em rádio e televisão, em eletrônica, em aviões a jato. Ameaçam-nos novas guerras mundiais, pois a consciência social do mundo ainda é primitiva." (NEILL, 1970, p. 22). 


\section{RESUMO}

TAVARES, Fernando Gomes de Oliveira. Práticas educacionais inovadoras e costumeiras: fatores de diferenciação. 2020. 141 f. Dissertação (Mestrado em Educação) - Faculdade de Educação, Universidade de São Paulo, São Paulo, 2020.

A discussão em torno do conceito de inovação evidenciou a ausência de uma investigação mais sólida na dimensão educacional. Tornou-se comum considerar mudança, reforma, renovação e inovação educacional como sinônimos que definem uma mesma realidade. Neste trabalho, emprego o conceito de inovação educacional para designar práticas que seguem uma lógica. Por essa lógica, tais práticas se distinguem de outras que são costumeiras em certo lugar, com certo grupo social. A presente pesquisa se orientou pelo seguinte problema: quais são os fatores que distinguem as práticas de inovação educacional das que são costumeiras em educação escolar? A hipótese era a de que, dentre tais fatores, são preponderantes: a organização do trabalho pedagógico e as relações pessoais estabelecidas no cotidiano escolar. Para examinar tal hipótese, observei a rotina de uma escola no município de Cotia: a Escola Projeto Âncora. As informações foram coletadas através da observação direta, entrevistas e registros de conversas informais com diferentes agentes do universo escolar. Os resultados apoiam-se na descrição das características marcantes das diferentes práticas educacionais em educação escolar. Concluo que a hipótese levantada foi confirmada.

Palavras-chave: inovação educacional; práticas educacionais; educação escolar. 


\begin{abstract}
TAVARES, Fernando Gomes de Oliveira. Práticas educacionais inovadoras e costumeiras: fatores de diferenciação. 2020. 141 f. Dissertação (Mestrado em Educação) - Faculdade de Educação, Universidade de São Paulo, São Paulo, 2020.

The discussion about the concept of innovation evidences the absence of a solid investigation in the educational dimension. It has become common to consider educational change, reform, renewal, and innovation as synonyms that define the same reality. In this thesis, I adopt the expression "educational innovation" to designate practices that follow a specific logic. By this logic, such practices are distinguished from others that are customary in a certain place, with a certain social group. The present research was guided by the following problem: what factors distinguish educational innovation practices from customary ones in school education? The hypothesis was that, among these factors, the following two are prevalent: the organization of the pedagogical work, and the personal relations established in the school's daily life. In order to inquire such hypothesis, I observed the routine of the "Projeto Âncora" school, in the city of Cotia (São Paulo, Brazil). Information was collected through direct observation, interviews and records of informal conversation with actors of the school universe. The results are based on the description of the most striking characteristics of different educational practices in school education. I conclude the hypothesis I had raised was confirmed.
\end{abstract}

Keywords: educational innovation; educational practices; schooling. 


\section{RESUMEN}

TAVARES, Fernando Gomes de Oliveira. Práticas educacionais inovadoras e costumeiras: fatores de diferenciação. 2020. 141 f. Dissertação (Mestrado em Educação) - Faculdade de Educação, Universidade de São Paulo, São Paulo, 2020.

La discusión sobre el concepto de innovación evidenció la ausencia de una investigación más sólida en la dimensión educativa. Se hizo común considerar el cambio, la reforma, la renovación y la innovación educativas como sinónimos que definen la misma realidad. En esta investigación, uso el concepto de innovación educativa para designar prácticas que siguen una lógica determinada. Según esta lógica, tales prácticas se distinguen de otras que son habituales en un determinado lugar, con un determinado grupo social. La presente investigación se guió por el siguiente problema: ¿cuáles son los factores que distinguen las prácticas de innovación educativa de las habituales en la educación escolar? La hipótesis era que, entre estos factores, son preponderantes: la organización del trabajo pedagógico y las relaciones personales establecidas en la vida diaria de la escuela. Con el intento de examinar la hipótesis, observé la rutina de una escuela en el ciudad de Cotia (São Paulo, Brasil): la "Escola Projeto Âncora". La información se recopiló mediante observación directa, entrevistas y registros de conversaciones informales con diferentes agentes del universo escolar. Los resultados se basan en la descripción de las características destacadas de las diferentes prácticas educativas en la educación escolar. Concluyo que la hipótesis planteada fue confirmada.

Palabras clave: innovación educativa; prácticas educativas; educación escolar. 


\section{Sumário}

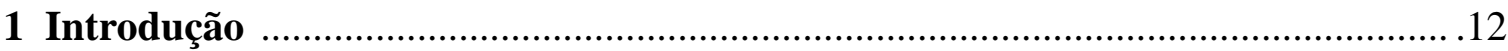

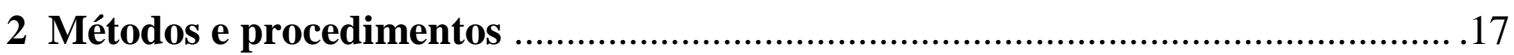

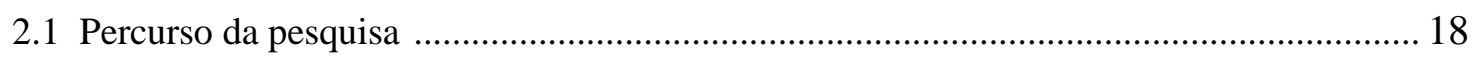

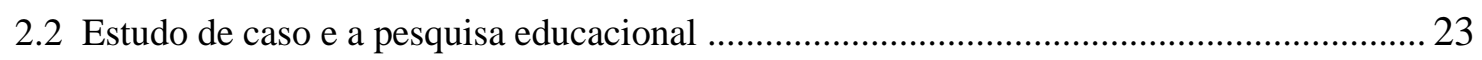

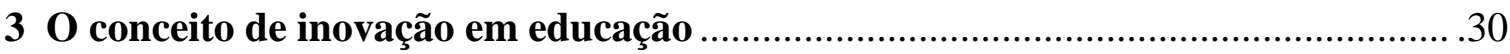

3.1 Um histórico interrompido da inovação educacional ................................................... 31

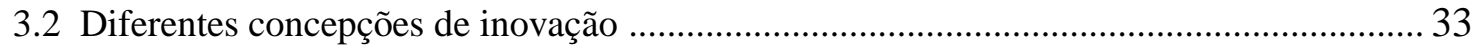

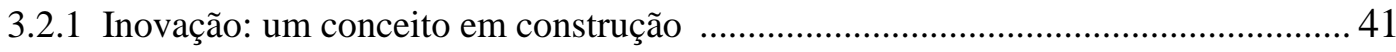

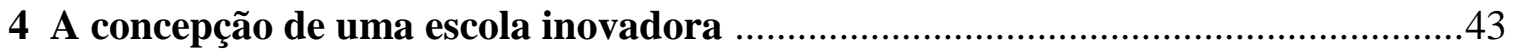

5 Práticas educacionais

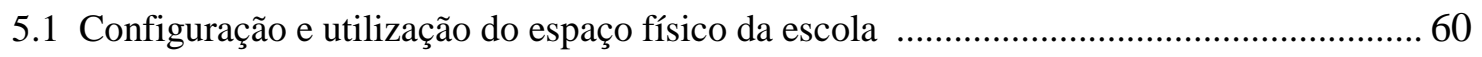

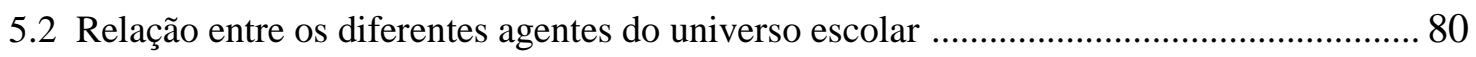

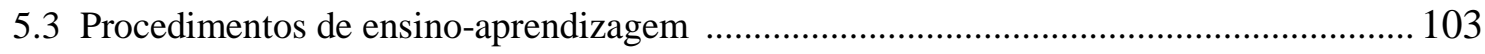

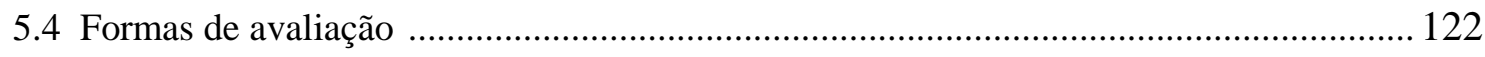

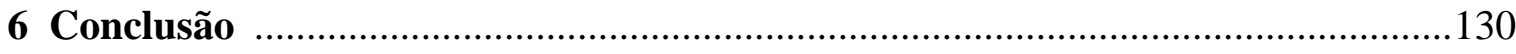

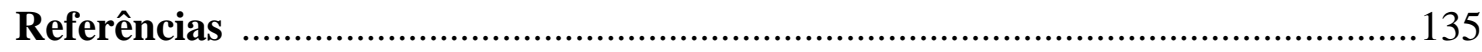




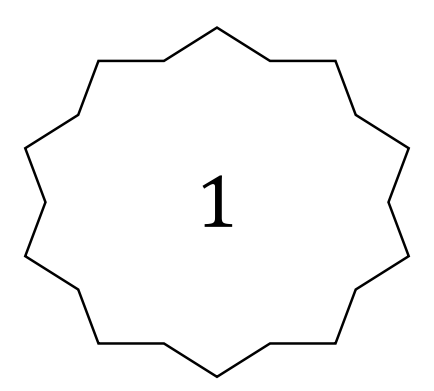

Introdução 
Esta pesquisa iniciou formalmente no ano de 2017. Digo formalmente porque o interesse pelo tema surgiu três anos antes do meu ingresso no mestrado. Em 2014, cursava geografia na Faculdade de Filosofia, Letras e Ciências Humanas da Universidade de São Paulo. Numa das disciplinas, denominada "Geografia Agrária II”, ministrada pela professora Valéria de Marcos, tive a oportunidade de participar de um trabalho de campo no Vale do Ribeira ${ }^{2}$ com o objetivo de conhecer algumas comunidades remanescentes de quilombos. A passagem por um dos quilombos, chamado "Terra Seca", proporcionou o contato com algumas crianças que, mal sabia eu, seriam o ponto de partida desta investigação. Essas crianças, que aparentavam ter entre 9 e 10 anos, estavam sentadas em círculo debatendo sobre algum assunto enquanto faziam anotações na terra com um pedaço de madeira. Ao ser questionada sobre a finalidade da atividade daqueles meninos por um dos graduandos que ali estava, a líder comunitária que nos guiava pelo quilombo respondeu, de forma natural: "eles estão em horário de aula". O grupo, que pareceu não ter ficado surpreso com a resposta, seguiu adiante para conhecer outras paragens do local. Minha reação foi diferente. Não consegui aceitar como meus colegas, de forma tão natural, aquela resposta. De fato, fiquei surpreso ao ver garotos e garotas estudando ao ar livre e, principalmente, ao vê-los sem a presença de um professor. Após a realização de outras atividades no local, sem muita importância para esse registro, a noite chegou e fui dormir.

Despertei no outro dia e aquele incômodo proporcionado pelo episódio das crianças ainda persistia. Foi aí que, ao tomar a decisão de dar uma volta pelo quilombo, fui abordado por um morador que, para minha surpresa, solicitava minha presença em uma roda de conversa com algumas moças e rapazes. Em contato com o grupo, descobri que esse morador era um dos professores do quilombo. Acabava de conhecer aquele personagem que procurei, sem lograr êxito, no dia anterior. Ele desejava que eu me apresentasse para aqueles estudantes, pois estavam curiosos com a presença de tantos desconhecidos em seu território. Em um determinado momento da minha apresentação, eu disse que era professor de geografia e um dos rapazes, interrompendo a minha fala, proferiu: "bem que você podia ser professor de tudo né? Geografia é só geografia. Aqui no quilombo, nossos professores falam de tudo, toda hora". Fiz uma pausa, pensei e balancei a cabeça demonstrando estar de acordo com o que o jovem havia dito. Isso, porém, não foi suficiente para que eu pudesse entender, naquele momento, a profundidade daquilo que o garoto havia falado. Não satisfeito, continuei me expressando, ou

2 O Vale do Ribeira é uma região localizada no sul do estado de São Paulo e leste do estado do Paraná. Recebe esse nome por ser banhado pelo rio Ribeira de Iguape. 
melhor, continuei monopolizando a fala e, quando estava prestes a cometer outro grande erro, perguntar se eles gostariam de ter uma aula de geografia, uma menina levantou a mão e disse: “você já viu batata-doce laranja?”. Respondi acenando com a cabeça negativamente. Todos levantaram ansiosamente e me levaram para conhecer a tal plantação de tuberosas. Foi assim que percebi que a relação entre educadores e educandos daquele lugar se dava de uma forma totalmente diferente de tudo que eu já havia conhecido até o momento. Ocorria ali, entre eles, um imenso respeito pelos interesses e saberes locais. As crianças daquela comunidade eram tão responsáveis quanto os adultos pelo desenvolvimento das práticas educacionais. Dessa forma, passei a considerar que era possível outro tipo de educação e decidi conhecer propostas alternativas ao modelo escolar costumeiro.

Considero esse ocorrido como o primeiro encontro com o tema em questão. Um verdadeiro despertar que serviu para aguçar a minha curiosidade. No entanto, houve um segundo momento tão significativo quanto esse para a construção desta pesquisa. Ocorreu em 2016, ao cursar a disciplina "Introdução aos estudos da educação: enfoque sociológico", ministrada pelo docente Elie Ghanem na Faculdade de Educação da Universidade de São Paulo (USP). O contato com esse docente foi crucial para o desenvolvimento deste trabalho porque, até então, dedicava-me apenas a conhecer novas experiências e conversar com alguns professores de escolas consideradas inovadoras. Era a primeira vez que encontrava alguém dedicado ao problema da inovação educacional e de posse de uma produção científica expressiva sobre o assunto. A partir das suas orientações e do contato com a literatura específica, o problema de pesquisa foi se desenhando até chegar à sua versão final, à qual este trabalho se dedicou: quais são os fatores que distinguem as práticas de inovação educacional das que são costumeiras em educação escolar? A hipótese era a de que, dentre os fatores que distinguem as práticas educacionais inovadoras das práticas costumeiras, são preponderantes: a organização do trabalho pedagógico e as relações pessoais estabelecidas no cotidiano escolar.

Inicialmente, o que se pretendia e foi proposto pelo projeto de pesquisa era realizar um estudo comparativo entre duas escolas no município de Cotia, na região metropolitana de São Paulo (SP). A primeira, Escola Estadual Fernando Nobre, foi escolhida por apresentar características educacionais consideradas costumeiras e a segunda, Escola Projeto Âncora, por representar os aspectos inovadores. Porém, já nos primeiros desdobramentos do percurso investigativo, essa opção foi se mostrando inviável. Primeiramente porque, após um trabalho de campo inicial, constatei que a instituição Fernando Nobre não era uma escola convencional, 
pois apresentava alguns fatores inovadores como, por exemplo, a participação ativa da comunidade na definição dos projetos educacionais e a construção coletiva dos diferentes documentos pedagógicos (Projeto Político-Pedagógico, planejamento anual, apostilas, planos de aula). Percebi que era mais viável adotar um modelo prévio, baseado na literatura, na minha trajetória docente e na minha própria formação escolar "tradicional", para o que julgo serem as práticas educacionais costumeiras. Por fim, a visita à Escola Projeto Âncora apontou para um quadro de observações bastante complexo, que demandaria um exame minucioso para a caracterização das práticas educacionais desenvolvidas ali. A partir dessas constatações, decidi concentrar a coleta de dados apenas nessa unidade escolar. Adotei-a de antemão como um modelo de práticas educacionais inovadoras e estabeleci uma posterior comparação com o que chamei de práticas costumeiras em educação escolar.

Penso que práticas educacionais são as diferentes ações entre os agentes do universo escolar que visam fornecer as condições necessárias para a aprendizagem. Tomo o devido cuidado para dissociar a concepção das práticas consideradas inovadoras das que são costumeiras. Entendo inovação educacional, amparado na acepção proposta por Ghanem (2012a, 2013a, 2013b), como uma tentativa de alteração das práticas educacionais consideradas costumeiras em um determinado local. Portanto, as práticas de inovação educacional não se distinguem por serem criativas, originais ou muito menos “tecnológicas”. Estão caracterizadas por serem diferentes de outras práticas educacionais que são comuns em um contexto social circunscrito. Assim sendo, reservo esse termo para as intervenções que têm lugar "embaixo", em nível local ou micro e que nada têm a ver com a ação reformadora dos governantes. Nesse sentido, a escola que inova é aquela que traz modificações nas práticas educacionais que são costumeiras dentro de um determinado grupo social. Levo em conta também que, conforme formulou Cândido (1964), toda escola é um grupo social, ou seja, detém uma sociabilidade própria resultante da ação combinada dos seus membros.

Costumeiras são aquelas práticas educacionais nas quais a principal preocupação é a de organizar o trabalho pedagógico na direção de uma transmissão de saberes considerados indispensáveis e legítimos, embora sejam dissociados das exigências mais cruciais dos diferentes grupos sociais. Geralmente, esses costumes seguem os modos contemporâneos de educação que estão baseados nos aspectos mais marcantes da chamada pedagogia tradicional. Nas escolas que operam segundo essa dinâmica, a ênfase é dada ao ensino e à aquisição do conhecimento. O professor é o centro desse conhecimento. Tal conhecimento é processado, 
preparado, aceito como verdadeiro e livre de dúvidas. O saber não é visto como o efeito de uma pergunta ou de uma busca pessoal, mas sim como um presente dado pelas autoridades aos estudantes. Assim, os conteúdos disciplinares estão no topo, são o fim da aprendizagem e não um meio para o desenvolvimento de habilidades e competências.

Notei que muitos trabalhos que tratam da inovação educacional apresentam dificuldades conceituais. Na maioria das vezes, utilizam uma linguagem extremamente técnica e demonstram uma tendência a entender a inovação como um processo administrativo, desconsiderando a importância do quadro social, cultural, histórico e político em que operam todas as inovações. Em trabalhos como A aventura de inovar (CARBONELL, 2002) e Inovar no interior da escola (THURLER, 2001), os empenhos têm se dirigido mais a difundir e modelizar experiências do que a compreendê-las em sua complexidade e integralidade no âmbito dos atores, processos, relações, dinâmicas, resistências, dilemas, conflitos e contradições. Com esta pesquisa, preencho essa lacuna ao promover uma investigação no sentido de contribuir para uma melhor compreensão das lógicas nas quais se situam os principais agentes envolvidos nas práticas educacionais, tanto as inovadoras quanto as costumeiras, dentro do universo escolar.

Para atingir tal propósito, divido o presente trabalho em cinco partes. Na primeira, discorro acerca do percurso metodológico desta investigação, explicito os procedimentos e as técnicas utilizadas na coleta de informações e, para arrematar, elaboro um paralelo entre o estudo de caso e a pesquisa educacional. Na segunda parte, exponho um breve histórico da inovação em educação e discuto diferentes concepções acerca desse fenômeno. Na terceira, apresento uma descrição densa sobre a origem e desenvolvimento da Escola Projeto Âncora. Na quarta, descrevo as práticas educacionais inovadoras e costumeiras e faço uma comparação segundo a organização do trabalho pedagógico e as relações pessoais estabelecidas no cotidiano escolar. Na quinta e última parte, concluo, a partir dos resultados obtidos, confirmando a hipótese inicial levantada por esta pesquisa. 


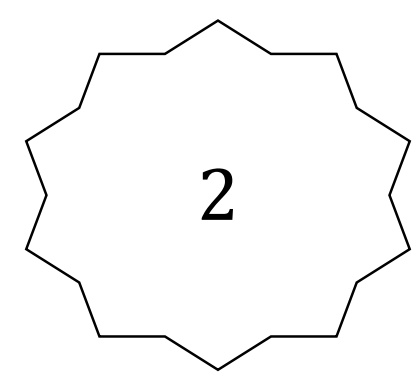

\section{Métodos e procedimentos}

Este capítulo apresenta os métodos e procedimentos empreendidos pela pesquisa. Por método, entende-se aqui o dispositivo de regras a serem seguidas para atingir um determinado objetivo, sendo que tais regras também podem ser incompatíveis no âmbito de uma dada prática científica. Dessa forma, como já tinha alertado Azanha (1992), afirmo a impossibilidade de um método geral e essencial à ciência, principalmente no que tange à atividade científica cujos objetos são as práticas educacionais. O procedimento, por sua vez, é considerado como a aplicação do plano metodológico, que engloba a sequência lógica das etapas propostas pela pesquisa e inclui o que comumente é chamado de técnica. Assim, o método organiza o raciocínio, e o procedimento obtém as informações. 


\subsection{Percurso da pesquisa}

Conforme dito na Introdução, esta pesquisa foi motivada pelo meu fortuito encontro com jovens quilombolas no interior de São Paulo e pela aproximação com o professor Elie Ghanem, que se tornou orientador do trabalho. Entretanto, se a partir dessas confluências a investigação já havia formado o seu objetivo, restava então definir seu modus operandi. A princípio, realizei um exame da literatura específica, não só para aprofundar-me no assunto, mas também para entender os possíveis sentidos atribuídos ao conceito de inovação em educação, uma vez que percebi que este termo era empregado indeliberadamente em diversos estudos. Os dados obtidos nessa fase resultaram na construção do terceiro capítulo deste trabalho. A primeira etapa exploratória foi importante para delimitar as unidades de análise e para elaborar uma estratégia de abordagem do objeto pesquisado.

A segunda etapa consistiu na coleta de informações em campo. Guiado pela necessidade de encontrar fatores distintivos entre práticas inovadoras e costumeiras, a intenção inicial foi escolher dois casos que pudessem representar esses aspectos para, depois, estabelecer uma comparação entre ambos. Essa escolha não foi feita ao acaso e se deu a partir de algumas características do que estou chamando de inovador e de costumeiro. Chamo de inovadoras as práticas educacionais que alteram condutas comuns em um grupo social específico, conforme propõe Ghanem (2012a, 2013a, 2013b). Denomino costumeiras as práticas educacionais que se preocupam em organizar o trabalho pedagógico no sentido de difundir saberes considerados imprescindíveis e legítimos, mesmo que estejam dissociados das necessidades mais vivas de um determinado grupo social. Adoto também essa ideia de grupo social acompanhando Cândido (1964), que vê toda escola como um agrupamento social dotado de uma estrutura própria, visto que sua formação é o resultado da ação combinada dos seus diferentes agentes a depender do contexto em que se insere. Com base nesses pressupostos teóricos, elegi a Escola Estadual Fernando Nobre como um possível caso de práticas costumeiras e a Escola Projeto Âncora como um possível caso de práticas inovadoras, ambas localizadas no mesmo bairro, na cidade de Cotia, SP.

Definidas as escolas, entrei em contato primeiro com a Fernando Nobre, em outubro de 2017, e consegui agendar a visita apenas para o final de janeiro do ano subsequente. Ao chegar ao local, conversei com o diretor e pedi sua autorização para acompanhar as diferentes atividades desenvolvidas no cotidiano escolar. Ele me concedeu permissão sem nenhum tipo 
de restrição. Assim, pude observar e registrar, durante três semanas seguidas, práticas como atribuição de aulas, definição do planejamento anual, aulas de diferentes disciplinas, reuniões de pais, oficinas, assembleias de estudantes e até mesmo um encontro da associação de pais e mestres (APM). Tudo isso foi o bastante para notar que a instituição mostrava diversos aspectos que não se encaixavam no rol das práticas costumeiras conforme eu havia previsto. Descobri que a Fernando Nobre era a única escola pública da região que tinha conquistado o direito, no ano de 2006, de ser uma escola em tempo integral, após um longo e intenso processo de lutas com o apoio da comunidade. Soube também que o diretor do estabelecimento recebeu o prêmio "Referências de Gestão e Liderança" da Secretaria da Educação do Estado de São Paulo pelo trabalho exercido frente a essa transição escolar. Segundo ele, "o prêmio foi uma forma de recuperar a autoestima da comunidade e dos alunos. Sem eles, eu seria um gestor do vazio com um trabalho sem sentido". Outros fatores também ajudaram a descartar a opção dessa escola como uma amostra de práticas educacionais costumeiras como, por exemplo, a proposição de oficinas extracurriculares pelos moradores do bairro, a produção de um jornal estudantil e o cultivo de uma horta orgânica destinada para o consumo na merenda escolar.

Contudo, antes de descartar por completo essa unidade escolar, resolvi visitar a segunda instituição, a Escola Projeto Âncora. As informações sobre essa escola, possibilitadas por amigos que a conheciam, pelos anúncios presentes na página do Ministério da Educação $(\mathrm{MEC})^{3}$ e pela tese de Quevedo (2014), apresentavam fortes indícios de que poderia se tratar de um caso exemplar de práticas educacionais inovadoras. Para verificar o que de fato ocorria nesse local, realizei minha primeira visita em fevereiro de 2018. Nessa ocasião, participei do que eles chamam de "vivência de um dia". Trata-se de uma visita guiada, com sete horas de duração, na qual o visitante tem contato com todos os ambientes de aprendizagem, conhece a história do projeto e participa de uma roda de conversa mediada por alguns educadores. Mesmo sendo aquela a primeira aproximação, e levando em conta que uma inovação não conduz necessariamente de uma situação considerada insatisfatória para outra melhor, foi possível ponderar que o caráter inovador do Âncora reside na participação ativa dos diferentes agentes do universo escolar na construção dos projetos educacionais. As diferentes atividades que acompanhei nesse dia se apresentaram como frutos de um acordo entre educadores e educandos. Era como se cada um soubesse das suas responsabilidades perante a Escola. Para se ter uma 
ideia, a minha "guia turística" no passeio pela instituição era uma menina de apenas 10 anos. Ela me recebeu pontualmente às 9 horas da manhã, na porta da escola e me apresentou um roteiro do que faríamos no dia; sabia meu nome completo, minha formação e o que eu pretendia com aquela visita. Também não foram poucas as vezes em que a vi dando instruções para outros jovens ou tomando de uma vassoura para tirar as folhas encontradas pelo caminho.

Confesso que fiquei impressionado com esse primeiro contato com a escola. No entanto, definido o local de observação para entender a inovação educacional, faltava por outro lado decidir o que seria feito para examinar as práticas educacionais costumeiras, já que a minha primeira opção havia se demonstrado inexequível. Uma conversa esclarecedora com meu orientador e a revisitação das minhas memórias escolares solucionaram essa questão. Em outras palavras, decidi resgatar minhas experiências como estudante e professor de escolas convencionais para determinar um parâmetro comparativo, sem a necessidade de eleger e descrever outras experiências educativas consideradas costumeiras. Essa opção se tornou mais viável não só por ajudar a revelar as diferenças e semelhanças entre o que se entende por essas práticas educacionais, mas também por acomodar melhor a dimensão do que se pretendia, desde o projeto de pesquisa, com a coleta de informações: realizar descrições densas a partir do método do estudo de caso.

Optei pelo estudo de caso devido à vantagem que oferece para ajudar a interpretar realidades educacionais dentro de um contexto cultural circunscrito. Irei me estender mais sobre essa relação entre estudo de caso e pesquisa educacional no próximo item deste capítulo. No entanto, adianto que os trabalhos de André (2005) e Yin (2014) apontam os benefícios dessa opção devido à sua adequação a uma análise profunda e minuciosa de um ou de poucos objetos, sempre com ênfase na singularidade. Dessa forma, procurei me distanciar da ingênua pretensão de generalização e me preocupei com o rigor descritivo das situações vivenciadas em campo, pois, embora acredite que a reconstituição do quadro real feita pelo pesquisador não seja a única correta ou possível, tenho a expectativa de que possa fornecer materiais suficientes para que o próprio leitor possa avaliar a fidedignidade do relato e a pertinência das interpretações.

Em um segundo momento, escolhi os procedimentos técnicos adequados para apoiar essa perspectiva. Além de ações próprias do estudo de caso, como a observação e o registro de anotações, também fiz uso da análise documental e de conversas informais com estudantes, professores(as), gestores(as), funcionários(as) não docentes e familiares. 
A preferência por esse tipo de conversa causou um grande impacto na forma como procedi em campo e no modo como estruturei este trabalho. As conversações seguiram a linha do reposicionamento do pesquisador no cotidiano, proposto por Spink (2008), e foram pautadas por um roteiro de observação baseado em duas variáveis analíticas: a organização do trabalho pedagógico e as relações pessoais no cotidiano escolar. A primeira via me ajudou a compreender os procedimentos de ensino, os modos de utilização do espaço escolar, a elaboração dos documentos pedagógicos, as formas de avaliação, a preparação do corpo docente e a concepção das suas finalidades educativas. Já a segunda facilitou meu entendimento sobre os conflitos, a relação da escola com os interesses da comunidade local, as atividades cooperativas e desagregadoras, o modo de formulação de decisões e as formas de participação dos diferentes agentes do universo escolar. Seus efeitos iniciais foram tão significativos e determinantes que acabei eliminando, no decorrer do processo, a realização de entrevistas semiestruturadas. Percebi que a ausência de um plano fixo e de um gravador facilitava a aproximação das pessoas. Estas sentiram-se mais confortáveis e produziram certos discursos aos quais, possivelmente, eu não teria acesso por meio da entrevista formal.

Apesar de parecer algo simplório, o estabelecimento das conversas informais desdobrou-se de uma forma bastante complexa. Primeiramente, precisei conquistar a confiança das pessoas e, para isso, tive que me tornar um visitante assíduo da Escola Projeto Âncora. Consegui até mesmo, por um brevíssimo período, me tornar um voluntário da instituição. Dessa maneira, atormentava os indivíduos com a minha pesquisa enquanto cooperava nos afazeres cotidianos. Após inúmeras visitas, pude aprender cada vez mais a voltar a minha atenção para o acaso diário, pois notei que as informações mais preciosas estavam presentes em tudo aquilo que era dito nas filas do almoço, nas salas de espera, corredores, escadas e em outros locais de breves encontros e de passagem. Obtive confissões intrigantes; a título de exemplo, em determinado dia um estudante proferiu, enquanto lavava as mãos no banheiro: "não sei porque tem tanta gente querendo entrar aqui no Âncora. Eu quero sair. Tenho saudades da minha antiga escola".

Esse período de visitação se deu no decorrer do ano de 2018. Presenciei muitas atividades como oficinas extracurriculares, assembleias, projetos comunitários, rodas de conversa, entre outras. No entanto, mesmo em posse de uma considerável carga horária de trabalho de campo, não pude acompanhar todos os eventos da escola. Creio que até mesmo se 
eu dobrasse esse tempo de visitação também não lograria êxito nisso, pois o Âncora é uma instituição extremamente ativa, onde o período de um dia parece ter a duração de 48 horas.

Ao finalizar a coleta de dados empíricos, a primeira tarefa foi organizar o registro das conversas informais. Dessa forma, pude analisá-las a partir da mesma abordagem, citada anteriormente, indicada por Spink (2008). Refere-se à separação das anotações em categorias temáticas, depois ampliadas, estabelecendo-se uma relação entre essas. Tal procedimento facilitou também a articulação dos discursos apreendidos com o que estava presente nos diversos documentos e vídeos institucionais que foram analisados.

Feita essa análise comparativa de todas as informações encontradas em campo, procurei identificar os principais fatores que diferenciam as práticas educacionais costumeiras das práticas educacionais inovadoras. Penso que a descrição robusta de tais aspectos contribuiu para verificar a hipótese inicial. Vale ressaltar também que a realização de leituras adequadas ao tema prosseguiu durante todo o percurso investigativo, de modo a ampliar o referencial teórico.

Um último alerta, antes do início do próximo item, se faz necessário. Optei pela omissão dos nomes de alguns entrevistados para evitar qualquer tipo de transtorno no interior da instituição educacional pesquisada. Apesar do fato de que todos no local estavam cientes da minha função de pesquisador e, por isso, compartilharam informações conscientes de que seriam divulgadas, muita coisa foi obtida informalmente, fruto de uma audição aguçada, para não dizer intrometida. Dessa forma, as identidades foram substituídas pelos postos ocupados no local durante o período de vigência desta investigação. 


\subsection{Estudo de caso e a pesquisa educacional}

Nas seções anteriores, expus as orientações que norteiam este trabalho. Tais orientações se baseiam em alguns procedimentos específicos que estão influenciando a minha atuação em campo e, principalmente, a redação desta pesquisa. O método eleito para guiar esses procedimentos foi o estudo de caso. No entanto, não pactuo com a ingênua visão de que atribuir um nome para um método estabelece o rigor científico de uma pesquisa. Creio que essa validação reside simplesmente no ato de explicitar as etapas seguidas pela investigação, ou seja, descrever em detalhes os caminhos percorridos para alcançar o objetivo geral, justificando cada escolha feita. Isso sim revela a rigorosidade científica de um trabalho, isto é, se foram tomados ou não os devidos cuidados durante a execução da coleta e análise de dados. Revela também a ética do pesquisador, que, ao demonstrar suas escolhas e convicções, permite que o leitor julgue seus valores e atitudes.

De acordo com essa proposição, de que o rigor metodológico não pode ser avaliado pela nomeação e aplicação de um método ou tipo de pesquisa específico, mas por uma descrição pormenorizada do caminho trilhado e das medidas escolhidas pelo pesquisador ao conduzir seu estudo, cabe esclarecer o que entendo por estudo de caso, contextualizá-lo, apresentar suas vantagens e desvantagens e demonstrar seu delineamento e sua relação com a pesquisa qualitativa em educação.

De longa data, o estudo de caso vem se encaminhando como uma forma de investigação em áreas como a sociologia, a medicina, a história, a psicologia, a administração, a antropologia ou o direito, cada uma buscando aprimorar ferramentas que tornem a abordagem mais apropriada a seus respectivos objetivos. Entretanto, o estudo de caso no âmbito educacional é algo mais recente. Pode-se dizer que seu marco foi a conferência "Métodos de Estudo de Caso em Pesquisa e Avaliação Educacional”, realizada em 1975, em Cambridge, Inglaterra. Esse evento, além de protagonizar inúmeras questões relacionadas ao uso dessa abordagem, ressaltou também a necessidade de esclarecer melhor os princípios teóricos e epistêmicos do estudo de caso na pesquisa educacional.

Até então, os estudos de caso em educação apareciam apenas em alguns manuais de metodologia científica com um sentido muito estreito: estudo meramente descritivo de uma unidade. Esses estudos eram classificados como "não experimentais", logo considerados menos 
"científicos" do que outros métodos amplamente utilizados naquele momento. Os pesquisadores que realizavam estudos de caso eram vistos como pessoas desviadas de suas disciplinas acadêmicas e seus trabalhos, como se tivessem uma precisão, rigor e objetividade insuficientes ao que se esperava.

Esse pensamento de "estudo descritivo de uma unidade", originado no contexto das abordagens quantitativas, permaneceu na pesquisa educacional até o final dos anos 1970, provocando alguns enganos e muitas críticas ao método. Após esse período, num campo de natureza qualitativa, o estudo de caso ressurgiu com um novo sentido, mais abrangente: o de destacar fenômenos particulares, considerando suas múltiplas características e contextos, onde o aspecto unitário ainda era valorizado, mas com a ressalva da necessidade de uma análise profunda e situada.

Apesar desse desenvolvimento nas discussões acerca do que seria um estudo de caso, muitos trabalhos ainda utilizavam a expressão de forma vaga, sem muita preocupação com a sua conceituação (MERRIAM, 1998). Até mesmo hoje, o emprego do estudo de caso é justificado apenas por definir um local específico. Utiliza-se caso com o sentido de lugar, ambiente, instituição ou indivíduo (como nos estudos de psicologia). Esse emprego intercambiável do caso como sinônimo de unidade de análise fez com que essa escolha ficasse restrita a investigações de porções da realidade ou a situações extremamente pontuais, o que trouxe mais críticas quanto à validade desse método. Por exemplo, um pesquisador visita uma determinada escola para coletar dados, faz algumas entrevistas e arremata: "isto é um estudo de caso". Afinal de contas, ele compareceu a uma escola...

O estereótipo de "parente pobre" entre os métodos sociológicos, atribuído ao estudo de caso, começou a se desfazer somente com a chegada de obras importantes sobre o assunto como Case study research: design and methods de Yin, publicado originalmente em 1984, e The art of case study research de Stake, publicado em $1995^{4}$. No Brasil, o primeiro estudo de grande relevância sobre o tema foi publicado por André (2005), intitulado Estudo de caso em pesquisa e avaliação educacional.

4 Segundo André (2005), orientanda brasileira de Stake na época, esse livro foi finalizado no término dos anos 1970 mas demorou um longo período para ser publicado devido às inúmeras críticas que eram feitas pelos pesquisadores de educação a esse tipo de pesquisa. 
Yin (2014) define o estudo de caso como uma investigação empírica que, utilizando múltiplas fontes de evidência, examina um determinado fenômeno em profundidade dentro de seu contexto de vida real, particularmente quando as fronteiras entre contexto e fenômeno não estão claramente estabelecidas. Em outras palavras, a adoção do método de estudo de caso se justifica quando o pesquisador deseja lidar com um caso do mundo real e concorda que sua compreensão envolve aceitar condições contextuais pertinentes ao objeto de estudo. Em comparação, um experimento laboratorial, por exemplo, separa um fenômeno de seu contexto e se dedica ao controle de apenas algumas variáveis.

O autor também aponta três situações nas quais o estudo de caso é indicado. A primeira ocorre quando o caso em questão é extremo ou único. A segunda situação é quando o caso serve para testar uma hipótese ou teoria previamente estabelecida. A terceira acontece quando o pesquisador tem contato com um objeto até então inabordável à investigação científica. Para Yin, os estudos de caso representam a estratégia ideal quando se apresentam questões do tipo "por que" e "como" e quando o pesquisador possui pouco controle sobre os possíveis acontecimentos.

Yin apresenta, ainda, duas variações do estudo de caso que, segundo ele, não só atendem a interesses distintos, mas também podem requisitar diferentes orientações metodológicas. Há o que ele chama de estudo de caso singular, quando o pesquisador visa observar um fenômeno significativo em raras circunstâncias, onde o propósito é descrever detalhadamente um objeto restrito. Há também a segunda variação, que ele denomina de estudo de caso múltiplo, quando o pesquisador tem a intenção de comparar diferentes situações para esclarecer se o resultado é uma simples característica peculiar de um caso ou uma replicação de inúmeros casos. Segundo o autor, essa última vertente provê uma teoria mais robusta, uma vez que a exploração e a elaboração teórica tornam-se mais amplas.

Embora haja algumas divergências, Stake (1995) parece concordar com Yin sobre o fato de que o estudo de caso consiste em investigar uma certa unidade situada em seu contexto, selecionada a partir de critérios predeterminados. Mas, segundo este autor, nem tudo pode ser considerado um caso. Para ele, um caso é um sistema delimitado cujas partes são integradas. Assim, uma escola, por exemplo, deve ser abordada como um ambiente circunscrito, embora a influência dos diversos aspectos que interagem com essa instituição, como o contexto histórico, sociocultural e econômico, não deva ser ignorada. 
Stake também distingue três tipos de estudos de caso a partir de seus objetivos: intrínseco, instrumental e coletivo. O caso intrínseco é caracterizado pela necessidade de apreender uma situação particular. Já no caso instrumental, ao contrário, o interesse reside em compreender uma situação mais ampla para contestar uma generalização aceita. Nessa situação, pode-se escolher uma escola para entender, por exemplo, a incorporação de uma política educacional no seu cotidiano. O estudo de caso coletivo consiste no estudo de vários casos, intrínsecos ou instrumentais, para abordar um dado objeto. Conclui-se, portanto, que os estudos de caso coletivos e instrumentais servem para favorecer ou contestar uma generalização aceita pela comunidade científica, enquanto os casos intrínsecos, num primeiro momento, não se preocupam com isso.

Outro aspecto que se faz necessário compreender é a forma de condução de um estudo de caso, ou melhor, o delineamento da pesquisa. Para isso, André (2005) destaca alguns pressupostos básicos que devem ser considerados pelo pesquisador ao optar pelo uso desse método: 1) o conhecimento está constantemente em construção; 2) o caso compreende uma dimensão plural; e 3) a realidade pode ser apreendida sob diversas óticas. O primeiro pressuposto demanda uma atitude flexível por parte do pesquisador, que se apoia em referências teóricas, mas não se concentra rigidamente nelas, pois fica alerta aos novos acontecimentos que podem aparecer no decorrer do trabalho. O segundo pressuposto exige que o pesquisador manipule uma variedade de procedimentos de coleta, de fontes de dados, de técnicas e instrumentos, para contemplar as várias dimensões do fenômeno investigado, evitando interpretações unilaterais. O terceiro e último pressuposto implica uma postura ética do pesquisador, que deve providenciar ao leitor as evidências que utilizou para realizar suas análises, ou seja, descrever de forma detalhada os eventos, pessoas e situações que foram observadas. De posse desses elementos, o leitor poderá concordar ou não com as interpretações apresentadas pelo pesquisador, além de construir suas próprias generalizações.

Mesmo admitindo que a pesquisa é uma atividade criativa, André indica que o desenvolvimento dos estudos de caso segue, em geral, quatro fases: a fase exploratória ou de definição dos focos de estudo, a fase de coleta ou delimitação do estudo, a fase de análise sistemática dos dados e, enfim, a fase de elaboração do relatório final.

A fase exploratória é o momento de definição das unidades de análise, o caso. Há dois aspectos, segundo a autora, que devem ser considerados nessa escolha: o caso precisa apresentar 
uma particularidade que merece ser investigada; e devem ser levantados aspectos prévios para caracterizar a unidade em questão. No entanto, apesar de seguir esse roteiro na construção deste trabalho, penso que o mais importante nessa fase é que haja critérios explícitos na seleção do caso, cuja relevância possa justificar o esforço para sua compreensão. Outro ponto importante nessa etapa é que o propósito de uma revisão de literatura se altera: ao invés de simplesmente ler para determinar as respostas sobre o que se sabe a respeito de um tema, a bibliografia específica é analisada para desenvolver questões mais perspicazes sobre o que se pretende investigar.

Uma vez definidos os elementos básicos do estudo, o pesquisador pode seguir para a segunda fase: a coleta de dados. Esse estágio vai requerer o uso de três principais técnicas: observação, entrevista e análise documental. A observação dirige a atenção do pesquisador para a compreensão do caso. A entrevista consiste em fazer perguntas e ouvir atentamente, uma ação simples e difícil ao mesmo tempo. A análise documental, seja sobre documentos pessoais, legais ou administrativos, pode complementar ou substituir, por exemplo, um evento que o pesquisador não conseguiu observar diretamente. Embora se tenha dado destaque a essas três técnicas como principais formas de coleta de dados, há outras que podem ser associadas a essas, como, por exemplo, grupos focais, memoriais, mapas conceituais e dados estatísticos.

A terceira fase do estudo de caso consiste em analisar sistematicamente os dados. Apesar dessa apresentação sequencial, André explica que a análise está presente nos diferentes momentos da pesquisa, tornando-se mais expressiva e formal após o término da coleta de dados. A primeira iniciativa é organizar todas as informações coletadas, separando-as segundo o tipo de instrumento, fonte de coleta ou ordem cronológica. O passo seguinte é a releitura de todo o material para detectar pontos relevantes e iniciar a construção das categorias de análise. A categorização inicial será examinada e possivelmente modificada, num momento posterior, onde características comuns serão reunidas e novas combinações ou fragmentações serão feitas. Essa organização dos dados em categorias por si só não esgota a análise. É necessário que o pesquisador extrapole a descrição, buscando relacionar e acrescentar coisas relevantes que já conhece sobre o assunto, numa dinâmica constante que deve perdurar até o final do relatório.

Por fim, a última fase que se apresenta é a elaboração do relatório final. Essa fase, como alerta André, é o grande desafio do estudo de caso, pois exige uma determinada habilidade escrita por parte do pesquisador. Os relatórios geralmente apresentam uma descrição 
robusta aliada a um estilo narrativo e ilustrada pelas experiências pessoais vividas em campo. Há também uma séria preocupação com a transmissão clara e direta de um caso, sempre procurando aproximar-se do leitor. Apesar dessas dificuldades, pude encontrar um grande auxílio para o processo de escrita na leitura de contos e de livros da antropologia.

Resta discorrer sobre a validade científica de um estudo de caso, pois, embora esse método seja uma forma distintiva de investigação empírica, a comunidade científica demonstra um certo desapreço para com ele. Melhor dizendo, enquanto estratégia de pesquisa os estudos de caso vêm sendo julgados como uma forma menos importante do que, por exemplo, levantamentos ou experimentos. Segundo Yin (2014), a crítica mais dirigida ao estudo de caso é a de que essa estratégia oferece uma base ínfima para se fazer uma generalização.

Como generalizar a partir de um caso único? Essa é uma questão muito ouvida. Uma breve resposta é que os estudos de caso são generalizados a partir de teorias que poderiam ser aplicadas a outros contextos, e não a universos ou populações. Esse processo Yin (2014) denomina "generalização analítica". Dessa forma, o autor aponta que sempre é possível gerar hipóteses que possam ser testadas em outros lugares (replicação) e, caso sejam confirmadas, podem ser generalizadas para contextos semelhantes.

Stake (1995) assume uma posição distinta sobre a generalização. O autor aponta que o importante é aprimorar a compreensão do caso em vez de priorizar a generalização para além do caso. Ele sugere que a responsabilidade de generalizar deve ser deixada para o leitor. Este, ao se confrontar com a descrição detalhada do objeto de estudo, decidirá se os resultados e as interpretações apresentados poderão ser aplicados ou não ao caso de seu apreço. Assim, o que se apreende sobre um determinado caso irá se relacionar ao fato de que este será semelhante ou diferente de outros já conhecidos. Pesquisadores etnográficos, por exemplo, relatam seus casos esperando que sejam confrontados a outros e, por esse motivo, optam por descrevê-los minuciosamente para que o leitor realize suas comparações.

Considero relevante essa preocupação dos autores em torno da validação do estudo de caso. No entanto, penso que nenhum conhecimento científico é inteiramente objetivo. Os valores e crenças daquele que investiga interferem na criação do trabalho e, nesse caso, a única pretensão de objetividade deveria ser aquela que resulta da exibição dos nossos resultados à crítica dos pares. Assim, o processo de produção do conhecimento pode ser visto como uma 
conversa contínua entre pesquisadores de uma área. Participar dessa interlocução é essencial ao ofício do pesquisador, uma vez que é por meio desta que os novos conhecimentos poderão ser validados.

Quando um pesquisador não situa seu estudo em uma discussão mais ampla, ele reduz o problema estudado ao recorte de sua própria pesquisa, restringindo, assim, a oportunidade de aplicação das suas conclusões a outros contextos. Tal atitude pouco contribui para o avanço do debate científico e para a construção de novas teorias, resultando em estudos que só têm interesse para os que destes fizeram parte.

Talvez tenha sido esse tipo de postura que resultou na crença falsa de que o estudo de caso seja um método fácil de ser aplicado na condução de uma pesquisa e, por isso, é mais adequado aos pesquisadores iniciantes. Junta-se a isso também a falha comum de considerar o estudo de caso como uma espécie de estágio exploratório de outras estratégias de pesquisa. Em resposta às críticas, prefiro optar pela permanência do paradoxo: quanto "mais fácil" for um método de pesquisa, mais difícil será sua execução. 


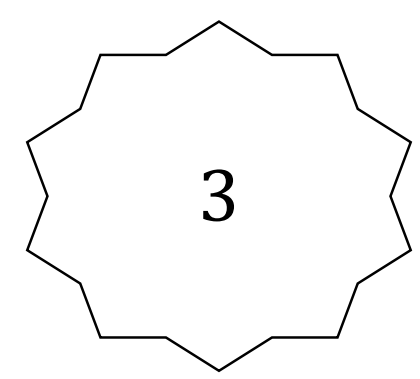

\section{O conceito de inovação em educação}

Este capítulo apresenta uma análise acerca do conceito de inovação presente nas pesquisas educacionais. Seleciona e examina um conjunto de 23 artigos científicos, indexados em duas bases de dados internacionais (SciELO e Web of Science), publicados no período de 1974 a 2017. Percebe-se aqui que a inovação é entendida sob quatro perspectivas: como algo positivo a priori, como sinônimo de mudança e reforma educacional, como modificação de propostas curriculares e como alteração de práticas educacionais costumeiras em um grupo social.

Esta seção divide-se em três partes. A primeira traça um breve panorama histórico da inovação dentro do contexto educacional. A segunda parte elucida as diferentes concepções de inovação. A terceira e última parte infere que o conceito de inovação possui uma ampla rede de significados que estão vinculados às diferentes concepções epistemológicas e ideológicas acerca do processo educativo. 


\subsection{Um histórico interrompido da inovação educacional}

A ideia de inovação, como tem sido engendrada por muitos, originou-se no ambiente empresarial. A área da produção tecnológica talvez seja uma das mais proeminentes quando se fala nesse assunto, uma vez que mostra com maior clareza a necessidade de inovar para não perecer no jogo do sistema capitalista. O propósito de analisar aqui o desdobramento desse termo dentro do contexto educacional advém do suposto de que a educação, em qualquer dos seus moldes e em qualquer das suas características, só adquire significação quando observada como parte do processo sócio-histórico.

No Brasil e em diversos países do continente europeu, as chamadas experiências inovadoras em educação manifestaram-se mais intensamente na década de 1960. Logo após, para promover uma reflexão sobre esse fenômeno, até então pouco expressivo no âmbito acadêmico, surge uma série de trabalhos publicados pela Organização das Nações Unidas para a Educação, Ciência e Cultura (Unesco) nos anos 70, entre os quais se destacam o livro de Huberman publicado em 1973 Comment s'opèrent les changements en éducation: contribution à l'étude de l'innovation e o de Havelock e Huberman (1977) Solving educational problems: the theory and reality of innovation in developing countries. Outro trabalho que evidenciou esse período inicial da discussão sobre inovação educacional foi o artigo publicado pela revista Interchange intitulado Overview of the innovative process and the user (1972), do canadense Michael Fullan.

Apesar das singularidades apresentadas por essas obras que marcaram a história da inovação no campo educacional, nota-se uma preocupação comum entre os autores, que está associada a uma intenção de generalização de princípios e de criação de modelos experimentais. Dessa forma, perdurou por algumas décadas a concepção de inovação como um processo que poderia ser planejado e controlado desde a sua implementação (GOLDBERG; FRANCO, 1980; MACLEAN, 1992).

O livro Inovação educacional no Brasil: problemas e perspectivas, publicado em 1980, reuniu textos de vários autores graças à iniciativa da Fundação Carlos Chagas. As três partes do livro discutem as dimensões, os problemas, as características e o futuro das inovações e também examinam alguns casos inovadores no Brasil. O ponto central da obra indaga sobre qual seria o objetivo da inovação em um país como o nosso. 
Após esse período, parece que as investigações iniciadas nesse campo temático foram interrompidas. Posso afirmar que não houve um avanço significativo da discussão acerca dos sentidos e contornos da inovação. Não apareceram outras obras de grande expressão que se propuseram debater sobre as diferentes acepções desse fenômeno dentro do contexto educacional. 


\subsection{Diferentes concepções de inovação}

Baseei-me no quadro síntese abaixo (Quadro 1) para averiguar o emprego do conceito de inovação nos artigos científicos presentes na área educacional. Trata-se de um exame de literatura para o qual foram coletados dados entre setembro de 2017 e março de 2018, em duas bases internacionais: Scientific Electronic Library Online (SciELO) e Web of Science. Utilizei a palavra-chave inovação em três idiomas (português, espanhol e inglês) contemplando todos os índices de busca. Não restringi o período e defini dois critérios de inclusão: abordar o fenômeno inovação dentro do contexto educacional e definir claramente o conceito de inovação. Após a aplicação desses filtros encontrei 56 registros publicados entre os anos de 1974 e 2017. Excluí as referências duplicadas e também aquelas que não se tratavam de artigos originais mas de editoriais, comentários e resenhas.

A partir desses critérios, selecionei 23 artigos. Esses trabalhos analisados correspondem ao período de publicação de 1974 a 2017. Dois foram publicados na década de 1970; outros dois, na década de 1990; nove artigos foram publicados entre 2000 e 2010 e, no período de 2011 a 2017, publicaram-se os outros dez artigos.

Michael Huberman e Michael Fullan tiveram suas obras citadas na maioria dos artigos. Destacaram-se, pelo número de ocorrências, os livros Comment s'opèrent les changements en éducation: contribution à l'étude de l'innovation, de Huberman (1973), e The new meaning of educational change, de Fullan (1982). Compreendo a importância desses autores, uma vez que seus trabalhos foram pioneiros, trazendo uma contribuição fundamental ao realizarem um esforço para conceituar a inovação no campo educacional, fenômeno até então ignorado pela comunidade científica.

Embora tais obras tenham se tornado decisivas para incluir a inovação no cenário educacional, os artigos resultantes do levantamento que fiz não os adotaram como pilares de suas teorias, ou seja, todos os autores se preocuparam em elaborar uma definição própria a respeito da inovação educacional. Isso demonstra a ausência de um consenso mínimo da comunidade científica acerca do significado de inovação, fator comum a outros objetos de investigação. Por esse motivo, realizei, nesta seção, uma classificação e agrupamento dos artigos examinados a partir de alguns aspectos interpretativos que os aproximam e os distanciam. Levei em conta critérios de análise como origem, valor e objetivo da inovação. 
Procurei também explicitar a opção sustentada pelos autores quanto ao enfoque e à importância atribuída à inovação. Essa categorização resultou em quatro grupos: 1) a inovação como algo positivo a priori; 2) a inovação como sinônimo de mudança e reforma educacional; 3) a inovação como modificação de propostas curriculares e; 4) a inovação como alteração de práticas educacionais costumeiras em um grupo social.

Quadro 1: Produção bibliográfica sobre inovação educacional.

\begin{tabular}{|c|c|c|c|c|}
\hline $\begin{array}{l}\mathrm{N}^{0} \text { do } \\
\text { artigo }\end{array}$ & $\begin{array}{l}\text { Autor e ano de } \\
\text { publicação }\end{array}$ & Título do artigo & Objetivo & Concepção de inovação \\
\hline 01 & Debeauvais, 1974 & $\begin{array}{l}\text { The popularity of the } \\
\text { idea of innovation: a } \\
\text { tentative interpretation } \\
\text { of the texts }\end{array}$ & $\begin{array}{l}\text { Analisar a popularização } \\
\text { da ideia de inovação } \\
\text { educacional }\end{array}$ & $\begin{array}{l}\text { Uma forma de aumentar a } \\
\text { eficiência operacional do } \\
\text { sistema educacional }\end{array}$ \\
\hline 02 & Hare, 1978 & $\begin{array}{l}\text { The concept of } \\
\text { innovation in education }\end{array}$ & $\begin{array}{l}\text { Refletir sobre o debate } \\
\text { acerca do conceito de } \\
\text { inovação em educação }\end{array}$ & $\begin{array}{l}\text { Uma alteração proposital que } \\
\text { possui significado e valor }\end{array}$ \\
\hline 03 & Aguerrondo, 1992 & $\begin{array}{l}\text { La innovación } \\
\text { educativa en América } \\
\text { Latina: balance de } \\
\text { cuatro décadas }\end{array}$ & $\begin{array}{l}\text { Evidenciar as diferenças } \\
\text { nos processos de } \\
\text { inovação educacional na } \\
\text { América Latina }\end{array}$ & $\begin{array}{l}\text { Toda tentativa de romper o } \\
\text { equilíbrio rotineiro do processo } \\
\text { educativo }\end{array}$ \\
\hline 04 & Moreira, 1999 & $\begin{array}{l}\text { Basta implementar } \\
\text { inovações nos sistemas } \\
\text { educativos? }\end{array}$ & $\begin{array}{l}\text { Apresentar referências } \\
\text { para melhor compreender } \\
\text { a implementação de } \\
\text { mudanças na escola }\end{array}$ & $\begin{array}{l}\text { Mudança planejada dentro do } \\
\text { sistema educacional }\end{array}$ \\
\hline 05 & Messina, 2001 & $\begin{array}{l}\text { Mudança e inovação } \\
\text { educacional: notas para } \\
\text { reflexão }\end{array}$ & $\begin{array}{l}\text { Explicar os diferentes } \\
\text { significados que podem } \\
\text { ser atribuídos ao conceito } \\
\text { de inovação }\end{array}$ & $\begin{array}{l}\text { Inovação como um tipo de } \\
\text { mudança intencional, } \\
\text { sistemática e autogerada }\end{array}$ \\
\hline 06 & Mitrulis, 2002 & $\begin{array}{l}\text { Ensaios de inovação no } \\
\text { ensino médio }\end{array}$ & $\begin{array}{l}\text { Examinar casos de } \\
\text { inovação ocorridos no } \\
\text { ensino médio }\end{array}$ & $\begin{array}{l}\text { Introduzir em determinado } \\
\text { meio algo que foi inventado, } \\
\text { com o objetivo de melhorar } \\
\text { aquilo que existe }\end{array}$ \\
\hline 07 & Veiga, 2003 & $\begin{array}{l}\text { Inovações e projeto } \\
\text { político-pedagógico: } \\
\text { uma relação regulatória } \\
\text { ou emancipatória? }\end{array}$ & $\begin{array}{l}\text { Discutir o significado de } \\
\text { inovação e projeto } \\
\text { político-pedagógico }\end{array}$ & $\begin{array}{l}\text { Uma ação que pode ser } \\
\text { regulatória ou emancipatória }\end{array}$ \\
\hline 08 & De Rossi, 2005 & $\begin{array}{l}\text { Mudança com máscaras } \\
\text { de inovação }\end{array}$ & $\begin{array}{l}\text { Refletir sobre as } \\
\text { armadilhas conceituais } \\
\text { resultantes do par } \\
\text { antigo/moderno no jogo } \\
\text { dialético da modernidade }\end{array}$ & $\begin{array}{l}\text { Processo de emancipação que } \\
\text { procura repensar a estrutura de } \\
\text { poder, as relações sociais e } \\
\text { seus valores }\end{array}$ \\
\hline 09 & Macías, 2005 & $\begin{array}{l}\text { Una conceptualización } \\
\text { comprehensiva de la } \\
\text { innovación educativa }\end{array}$ & $\begin{array}{l}\text { Analisar o conceito de } \\
\text { inovação educacional }\end{array}$ & $\begin{array}{l}\text { Aplicação duradoura de } \\
\text { estratégias criativas dos } \\
\text { processos de ensino e } \\
\text { aprendizagem } \\
\end{array}$ \\
\hline 10 & $\begin{array}{l}\text { Días-Barriga } \\
\text { Arceo, } 2010\end{array}$ & $\begin{array}{l}\text { Los profesores ante las } \\
\text { innovaciones } \\
\text { curriculares }\end{array}$ & $\begin{array}{l}\text { Revisar artigos que tratam } \\
\text { sobre inovação curricular } \\
\text { nas escolas mexicanas }\end{array}$ & $\begin{array}{l}\text { Mudança profunda nos } \\
\text { paradigmas e práticas sociais } \\
\text { em uma comunidade concreta }\end{array}$ \\
\hline 11 & Buzato, 2010 & $\begin{array}{l}\text { Cultura digital e } \\
\text { apropriação ascendente: } \\
\text { apontamentos para uma } \\
\text { educação } 2.0\end{array}$ & $\begin{array}{l}\text { Construir uma } \\
\text { perspectiva para os novos } \\
\text { letramentos digitais no } \\
\text { campo das discussões } \\
\text { correntes sobre inclusão } \\
\text { digital e inovação } \\
\text { tecnológica }\end{array}$ & $\begin{array}{l}\text { Propostas pedagógicas que } \\
\text { utilizam novas tecnologias }\end{array}$ \\
\hline 12 & Demo, 2010 & $\begin{array}{l}\text { Rupturas urgentes em } \\
\text { educação }\end{array}$ & $\begin{array}{l}\text { Discutir sobre as rupturas } \\
\text { necessárias no âmbito da } \\
\text { educação }\end{array}$ & $\begin{array}{l}\text { Rompimento das dinâmicas } \\
\text { educacionais vigentes }\end{array}$ \\
\hline
\end{tabular}




\begin{tabular}{|c|c|c|c|c|}
\hline 13 & $\begin{array}{l}\text { Monteiro; Smole, } \\
2010\end{array}$ & $\begin{array}{l}\text { Um caminho para } \\
\text { atender às diferenças na } \\
\text { escola }\end{array}$ & $\begin{array}{l}\text { Analisar modificações } \\
\text { ocorridas em uma escola } \\
\text { judaica do RJ após a } \\
\text { implementação do } \\
\text { Programa de Inovação } \\
\text { Educativa (PIE) }\end{array}$ & $\begin{array}{l}\text { Método de ensino alternativo } \\
\text { dentro da educação formal }\end{array}$ \\
\hline 14 & Fernandes, 2011 & $\begin{array}{l}\text { Inovações curriculares: } \\
\text { o ponto de vista de } \\
\text { gestores de escolas do } \\
\text { ensino básico em } \\
\text { Portugal }\end{array}$ & $\begin{array}{l}\text { Analisar os discursos de } \\
\text { professores/as em } \\
\text { exercício de gestão que } \\
\text { participaram de projetos } \\
\text { educacionais inovadores }\end{array}$ & $\begin{array}{l}\text { Ruptura com situações ou } \\
\text { práticas educacionais } \\
\text { anteriores }\end{array}$ \\
\hline 15 & $\begin{array}{l}\text { Díaz-Barriga } \\
\text { Arceo, } 2012\end{array}$ & $\begin{array}{l}\text { Reformas curriculares y } \\
\text { cambio sistémico: una } \\
\text { articulación ausente } \\
\text { pero necesaria para la } \\
\text { innovación }\end{array}$ & $\begin{array}{l}\text { Estudar as principais } \\
\text { inovações curriculares } \\
\text { vinculadas aos processos } \\
\text { de reforma curricular } \\
\text { empreendidos no México }\end{array}$ & $\begin{array}{l}\text { Mudança profunda nos } \\
\text { paradigmas e práticas sociais } \\
\text { em uma comunidade concreta }\end{array}$ \\
\hline 16 & Ghanem, 2012b & $\begin{array}{l}\text { Inovação educacional } \\
\text { em pequeno município } \\
\text { - o caso Fundação Casa } \\
\text { Grande (Nova Olinda, } \\
\text { CE, Brasil) }\end{array}$ & $\begin{array}{l}\text { Examinar os fatores que } \\
\text { se conjugam na geração } \\
\text { de ações de inovação } \\
\text { educacional (Fundação } \\
\text { Casa Grande) }\end{array}$ & $\begin{array}{l}\text { Práticas educacionais que se } \\
\text { distinguem de outras que são } \\
\text { costumeiras em determinado } \\
\text { grupo social }\end{array}$ \\
\hline 17 & $\begin{array}{l}\text { Hofman; Boom; } \\
\text { Meeuwisse; } \\
\text { Hofman, } 2012\end{array}$ & $\begin{array}{l}\text { Educational innovation, } \\
\text { quality, and effects: an } \\
\text { exploration of } \\
\text { innovations and their } \\
\text { effects in secondary } \\
\text { education }\end{array}$ & $\begin{array}{l}\text { Compreender o } \\
\text { funcionamento da } \\
\text { inovação na educação } \\
\text { secundária }\end{array}$ & $\begin{array}{l}\text { Mudanças substanciais com a } \\
\text { introdução de novos tipos de } \\
\text { aprendizagem }\end{array}$ \\
\hline 18 & Ghanem, 2013a & $\begin{array}{l}\text { Inovação em escolas } \\
\text { públicas de nível } \\
\text { básico: o caso Redes da } \\
\text { Maré (Rio de Janeiro, } \\
\text { RJ) }\end{array}$ & $\begin{array}{l}\text { Examinar os fatores que } \\
\text { se conjugam na geração } \\
\text { de ações de inovação } \\
\text { educacional (Redes da } \\
\text { Maré) }\end{array}$ & $\begin{array}{l}\text { Práticas educacionais que se } \\
\text { distinguem de outras que são } \\
\text { costumeiras em determinado } \\
\text { grupo social }\end{array}$ \\
\hline 19 & Ghanem, 2013b & $\begin{array}{l}\text { Inovação em educação } \\
\text { ambiental na cidade e } \\
\text { na floresta: o caso Oela }\end{array}$ & $\begin{array}{l}\text { Examinar os fatores que } \\
\text { se conjugam na geração } \\
\text { de ações de inovação } \\
\text { educacional (Oela) }\end{array}$ & $\begin{array}{l}\text { Práticas educacionais que se } \\
\text { distinguem de outras que são } \\
\text { costumeiras em determinado } \\
\text { grupo social }\end{array}$ \\
\hline 20 & Marcelo, 2013 & $\begin{array}{l}\text { Las tecnologías para la } \\
\text { innovación y la práctica } \\
\text { docente }\end{array}$ & $\begin{array}{l}\text { Analisar a escola como } \\
\text { uma inovação da } \\
\text { tecnologia espacial }\end{array}$ & $\begin{array}{l}\text { Processo de mudança } \\
\text { amparado pela inclusão de } \\
\text { novos aparatos tecnológicos } \\
\text { no ambiente escolar }\end{array}$ \\
\hline 21 & $\begin{array}{l}\text { Nogaro; Battestin, } \\
2016\end{array}$ & $\begin{array}{l}\text { Sentido e contornos da } \\
\text { inovação na educação }\end{array}$ & $\begin{array}{l}\text { Debater sentidos e } \\
\text { conotações do conceito de } \\
\text { inovação educacional }\end{array}$ & Recriar ideias pedagógicas \\
\hline 22 & $\begin{array}{l}\text { Leal-Soto; } \\
\text { Hernández; } \\
\text { Parada, 2016 }\end{array}$ & $\begin{array}{l}\text { Liderazgo directivo y } \\
\text { condiciones para la } \\
\text { innovación en escuelas } \\
\text { chilenas: el que nada } \\
\text { hace, nada teme }\end{array}$ & $\begin{array}{l}\text { Discutir sobre a relação } \\
\text { entre liderança e inovação } \\
\text { no contexto educacional } \\
\text { chileno }\end{array}$ & $\begin{array}{l}\text { Processo complexo e } \\
\text { colaborativo que diz respeito à } \\
\text { seleção, organização e uso } \\
\text { criativo de elementos de } \\
\text { gestão institucional, curricular } \\
\text { e didática, geralmente em } \\
\text { resposta a um problema ou } \\
\text { necessidade }\end{array}$ \\
\hline 23 & Carrier, 2017 & $\begin{array}{l}\text { How educational ideas } \\
\text { catch on: the promotion } \\
\text { of popular education } \\
\text { innovations and the role } \\
\text { of evidence }\end{array}$ & $\begin{array}{l}\text { Explorar as técnicas de } \\
\text { persuasão utilizadas em } \\
\text { documentos que tratam } \\
\text { das inovações educativas } \\
\text { populares de diferentes } \\
\text { tipos }\end{array}$ & $\begin{array}{l}\text { Ideias, práticas, produtos e } \\
\text { serviços que mudam o sistema } \\
\text { em que são introduzidos }\end{array}$ \\
\hline
\end{tabular}

Fonte: Organização própria a partir de dados presentes nas plataformas SciELO e Web of Science.

A inovação esteve relacionada a algo positivo a priori em sete estudos (artigos 01, 06, 07, 09, 13, 22, 23). A adoção da inovação como panaceia para os problemas educacionais e a introdução de estratégias originais para melhorar as práticas educacionais vigentes foram outros 
dois fatores que aproximaram esses trabalhos. Observei também que os autores foram guiados por uma lógica indutiva na construção dos seus artigos, isto é, analisaram experiências particulares e teorizaram sobre estas.

No artigo de Mitrulis (2002), que teve como objetivo o exame de casos de inovação ocorridos no ensino médio, pude notar uma noção de inovação como algo que deve ser introduzido em determinado meio com o objetivo de melhorar as atividades ali existentes. Nos casos avaliados pela autora, foram priorizadas questões referentes à gestão escolar, ao trabalho coletivo e à articulação com agências externas para a constituição de projetos educativos. Para Mitrulis, as inovações devem ser produzidas pelos atores em seu cotidiano e precisam estimular o protagonismo dos jovens envolvidos com a instituição de ensino. Esse posicionamento da pesquisadora aponta uma separação entre a lógica da reforma e a lógica da inovação. A primeira se materializa na ação própria das autoridades e a outra, no exercício dos agentes educacionais mais próximos da base do sistema escolar. No entanto, mesmo admitindo essa divisão, o artigo demonstrou uma incoerência ao ambicionar "colaborar com a formulação de políticas de apoio e de orientação às escolas” (p. 217), o que atribuiu um aspecto prescritivo ao conceito de inovação, embora tenha procurado deste se afastar.

De posse da mesma preocupação com a lógica reformista da inovação, Veiga (2003) procurou discutir o significado de inovação sob duas perspectivas: como uma ação regulatória e como uma ação emancipatória. Segundo a autora, a inovação de cunho regulatório dispõe de um caráter normativo e autoritário, reside dentro de uma lógica cognitiva-instrumental e se preocupa em padronizar e controlar burocraticamente os mecanismos inovadores. Trata-se de um "conjunto de ferramentas (diretrizes, formulários, fichas, parâmetros, critérios etc.) proposto em nível nacional” (p. 271). Já a inovação emancipatória é concebida como uma ação que ultrapassa as questões meramente técnicas, que conta com uma maior articulação com os saberes locais e que deslegitima as forças institucionais. Na acepção de Veiga, falar sobre inovação só tem sentido se a preocupação fundamental for melhorar a qualidade da educação para que "todos aprendam mais e melhor" (p. 268). Tal afirmação sustenta a crença da pesquisadora na função positiva intrínseca das práticas inovadoras.

Preocupados com a construção de novos elementos para serem utilizados no ensino, os artigos Una conceptualización comprehensiva de la innovación educativa (MACÍAS, 2005), Liderazgo directivo y condiciones para la innovación en escuelas chilenas: el que nada hace, 
nada teme (LEAL-SOTO; HERNÁNDEZ; PARADA, 2016) e Um caminho para atender às diferenças na escola (MONTEIRO; SMOLE, 2010) adotaram a inovação como um processo que diz respeito à aplicação de estratégias criativas em resposta a determinadas necessidades originadas no contexto escolar. Em todos, a inovação é um modelo centrado na resolução de problemas, ou seja, um conjunto de procedimentos que devem ser executados de modo a alcançar uma melhora da situação preexistente. Os autores associam essa visão positiva ao sentido etimológico do termo inovação (innovare), que deriva da palavra novo (novus), onde a novidade se sobrepõe àquilo que está ultrapassado gerando um aperfeiçoamento.

Dissociando-se dessa visão que busca encontrar um modelo inovador ideal, e com um objetivo de explorar as técnicas utilizadas em documentos que tratam de inovações educativas populares, Carrier (2017) e Debeauvais (1974) concebem a inovação como uma estratégia para aumentar a eficiência operacional do sistema educacional em que é introduzida. Nesse sentido, para esses autores, a inovação não é apenas algo novo, mas algo que se destina a produzir melhora, e que necessita apresentar resultados de tal melhoria. O que implica, na prática, seguir um caminho que se fundamenta no controle e avaliação de ações inovadoras. Resumindo, percebo que dentro dessa abordagem só será considerado inovador aquilo que obtiver resultados positivos segundo os objetivos definidos por uma apreciação daqueles que controlam o processo.

Uma segunda categoria de interpretação é a inovação como sinônimo de mudança e reforma educacional. Esse tipo de compreensão esteve presente em cinco estudos analisados (artigos 04, 05, 12, 17, 21). A inovação educacional foi tratada nesses trabalhos pelo emprego alternado, mas com o mesmo propósito explicativo, dos termos mudanças e reforma. Ao contrário dos autores apresentados pela primeira categoria de análise, estes assumiram uma visão mais crítica a respeito do processo de inovação, ao não adotarem um valor positivo ou negativo de antemão. Outro aspecto relevante reside no fato de que ambos os grupos de autores reconheceram as inovações nas escolas como detentoras de um caráter complexo e, por isso, decidiram interpretá-las como um processo e não como um evento.

Três trabalhos definiram a inovação como uma mudança dentro do sistema educacional. O primeiro é o de Moreira (1999), que investigou a implementação de mudanças na escola. O segundo é de Hofman, Boom, Meeuwisse e Hofman (2012), que buscou compreender o funcionamento da inovação na educação secundária. E o terceiro trabalho é o 
de Nogaro e Battestin (2016), que procurou debater os possíveis sentidos e conotações do conceito de inovação na prática educativa.

Já dois artigos conceberam a inovação como um tipo de reforma que rompe com as dinâmicas educacionais vigentes. O primeiro é o trabalho de Demo (2010), que discutiu sobre as transformações necessárias dentro do sistema educacional. O segundo é o de Messina (2001), que explicou os diferentes significados que podem ser atribuídos ao conceito de inovação.

A inovação, tanto na esfera da mudança quanto na esfera da reforma, foi classificada, pelos artigos, de diferentes modos (pedagógica, institucional, imposta, voluntária). No entanto, os trabalhos apresentaram uma preocupação de origem comum: os efeitos da inovação no nível macro. Tais efeitos apareceram relacionados à criação de novas ideias pedagógicas, materiais didáticos, tecnologias de informação, técnicas de ensino e diversas alterações do ambiente escolar. Nessa perspectiva, a inovação educacional se coloca como uma estratégia que parte do centro do sistema escolar, logo, um mecanismo a mais de ordenação pedagógica e social.

Dentro de uma terceira via analítica, tem-se a inovação percebida como uma modificação de propostas curriculares, que esteve presente em seis artigos $(08,10,11,14,15$, 20). Por currículo, entendo aqui, na sua acepção mais comum, a organização de experiências de aprendizagem realizada para conduzir um processo educativo.

Nesse âmbito, De Rossi (2005) refletiu sobre as armadilhas conceituais resultantes da associação da noção de antigo e moderno perante a dialética da modernidade. A partir de uma perspectiva marxista, ela define inovação como um processo de emancipação que procura repensar a estrutura de poder, as relações sociais e seus valores. Segundo a autora, a inovação educacional apoia-se sobre uma modernização educativa que compreende o "conjunto de estratégias adotadas por distintas instâncias e centros de poder para racionalizar os sistemas educativos" (p. 943).

Os dois artigos de Díaz-Barriga Arceo (2010, 2012) trataram das inovações curriculares empreendidas nas escolas mexicanas. De acordo com a autora, a inovação se caracteriza por ser uma mudança profunda nos paradigmas e práticas sociais em uma comunidade concreta. Para que isso aconteça, a pesquisadora defende que as práticas curriculares sejam desenvolvidas por meio da participação ativa dos professores. 
Sob essa mesma concepção de inovação como uma ruptura profunda de situações ou práticas educacionais anteriores, porém sob o ponto de vista do gestor como agente central desse processo, apresenta-se o artigo de Fernandes (2011). Ela analisou as políticas curriculares do ensino básico em Portugal no período de 1997 a 2006. Revelou que a descontinuidade dessas políticas é um fator que inibe a construção de práticas de inovação curricular:

\begin{abstract}
Perante as constantes alterações das políticas e a mudança permanente de direção a que são abruptamente sujeitos, os professores reconhecem "não valer a pena" os investimentos feitos na construção de processos de gestão curricular e expressam desejo de voltar ao modelo de "escola tradicional". Subjacente a esse desejo está também a ambição em ganharem "de novo" a centralidade e a autoridade que admitem terem "perdido". (p. 206)
\end{abstract}

Numa perspectiva da inovação curricular amparada pelo uso de novos aparatos tecnológicos no ambiente escolar, estão relacionados os artigos de Buzato (2010) e Marcelo (2013). Nos dois estudos, a inovação foi entendida como um processo que inclui produtos e atividades técnicas como propostas pedagógicas. Inovar, nesse caso, é uma invenção vinculada ao desenvolvimento tecnológico nas escolas e que está condicionada, em grande medida, ao desenvolvimento econômico. Em todo caso, os autores permitem um certo nível de interpretação que demonstra a confiança na operacionalização de ferramentas para a regularização do papel dos agentes educacionais, como se fosse uma forma de legitimação profissional através da técnica. As novas tecnologias simbolizam para eles, com grande propriedade, o que a inovação representa para o mundo corporativo, onde inovar é permanecer vivo e não inovar é perecer.

Por fim, apresento uma quarta categoria interpretativa que concebeu a inovação como uma alteração de práticas educacionais costumeiras em um determinado grupo social. Essa perspectiva foi exposta em cinco pesquisas de três diferentes autores (artigos 02, 03, 16, 18, 19). Esses autores se distanciaram de todos os aspectos estabelecidos pelos outros trabalhos analisados acima. Eliminaram a crença no valor positivo da inovação. Apresentaram argumentos para distinguir inovação, mudança e reforma. Assumiram a inovação como uma atividade comparativa realizada em um determinado contexto. E não se restringiram ao exame da inovação apenas no campo das práticas de ensino, mas, examinaram as condutas de diferentes agentes que compõem o processo educacional. 
Hare (1978) e Aguerrondo (1992) problematizaram, com o apoio de vários autores, a definição de inovação, notadamente no que tange ao caráter universal ou não de seus preceitos. Subjaz à discussão exibida nesses dois textos a inovação pensada como uma alteração proposital que possui significado e valor. A afirmação de que a inovação detém um valor, como salientam os autores, não deve ser confundida com a afirmação de que envolve um julgamento de valor, pois posso dizer que $\mathrm{X}$ é significativamente diferente de $\mathrm{Y}$ sem dizer que é melhor ou pior do que Y. Outro aspecto relevante apontado pelos pesquisadores é o fato de que as inovações são produzidas nas instituições de educação formal ou não formal por iniciativa dos tomadores de decisão locais, independente das autoridades responsáveis pelo sistema educativo. Tais inovações, segundo eles, diferem em vários aspectos daquelas alterações que são projetadas para serem seguidas por reformas educacionais em nível nacional.

Seguindo essa mesma vertente que faz questão de ressaltar a diferença escalar entre inovação, mudança e reforma, apresentam-se os três artigos de Ghanem (2012a, 2013a, 2013b). Para o autor, "a mudança educacional deve ser o produto da convergência de práticas advindas de duas lógicas de ação diferentes: a da inovação educacional e da reforma educacional" (2012, p. 104). O pesquisador também alerta para os objetivos das inovações, que não são necessariamente os do sistema educacional do qual se faz parte, pois não procuram necessariamente melhorar o funcionamento do sistema, mas buscam um tipo diferente de educação. Por esse motivo, muitas vezes, estão em conflito com o sistema.

\begin{abstract}
A lógica da inovação educacional orienta práticas que estão situadas na base de sistemas escolares, às vezes em estabelecimentos individualmente considerados e outras vezes em organizações locais entendidas como associações comunitárias. Ao seguirem a lógica da inovação, as práticas educacionais se diferenciam do que costuma ser praticado junto a determinado grupo social em determinado lugar. Assim sendo, a inovação não se distingue por qualquer qualidade original, antes, porém, está marcada por sua diferença em relação ao que é costumeiro. (2012a, p. 104-105)
\end{abstract}

Nessa leitura, não está implícito no termo inovação que uma prática educacional é bastante original na forma como uma primeira descoberta científica é. O posicionamento defendido é de que o termo inovação deve ser usado de forma comparativa. Assim, foi inovador na história recente da escolaridade quando professores e alunos começaram a se deslocar da sala de aula para a comunidade: embora isso tenha sido feito antes em outros contextos, pode ser julgado aqui como suficientemente diferente de um padrão de instrução que se tornou arraigado. A acupuntura, por exemplo, quando aprovada, consistiu em uma inovação na prática médica ocidental, embora seja uma prática oriental milenar. 


\subsubsection{Inovação: um conceito em construção}

Percebo que a inovação, palavra muitas vezes empregada indeliberadamente, é assumida nos artigos analisados como um valor positivo a priori, como sinônimo de reforma e mudança, como transformação de propostas curriculares e como alteração de práticas costumeiras em um determinado grupo social. À vista disso, considero que o conceito de inovação em educação, além de ser algo em construção permanente, detém uma ampla rede de significados que estão vinculados às diferentes concepções epistemológicas e ideológicas acerca do processo educativo. Dessa forma, não existe um marco de referência teórica suficientemente desenvolvido a respeito da conceituação da inovação em educação que possa orientar a investigação do pesquisador em campo. Por isso, nesta parte da pesquisa, efetuei uma tentativa para elucidar uma questão que se faz presente: de que inovação os trabalhos em educação estão falando?

Soma-se a esse fato o grande número de pesquisas que não definem claramente o que estão apontando como inovação, e a preponderância dos artigos que enunciam a inovação como um fim em si mesmo e como algo positivo para os problemas educacionais complexos. Essa vertente explicativa sobrepõe-se àquela que enxerga a inovação como uma atividade que pertence à base do sistema escolar e que não vê razão para que as pesquisas atribuam um julgamento positivo ou negativo a priori ao termo.

A discussão sobre inovação educacional deveria ser intensificada no contexto brasileiro, considerando que muitos trabalhos apresentam uma linguagem extremamente técnica e demonstram uma tendência a entender a inovação como um processo administrativo, desconsiderando a importância do quadro social, cultural, histórico e político em que operam todas as inovações. Noto que os empenhos têm se dirigido mais a difundir e modelizar experiências do que a compreendê-las em sua complexidade e integralidade no âmbito dos atores, processos, relações, dinâmicas, resistências, dilemas, conflitos e contradições.

Mesmo constatando a fragilidade teórica em torno do conceito de inovação, convém ressaltar que, como limitação deste estudo, busquei, por meio de uma seleção de artigos, apenas identificar o conceito de inovação e seus principais usos em trabalhos que versam sobre educação, motivo pelo qual não apontei reformulações aprofundadas sobre o objeto investigado. Apesar disso, resolvi adotar de antemão a concepção de inovação educacional 
como uma tentativa de alteração das práticas educacionais costumeiras em um determinado grupo social. Essa acepção guiou este trabalho, em termos conceituais, no que diz respeito à caracterização dos fenômenos observados na Escola Projeto Âncora. 


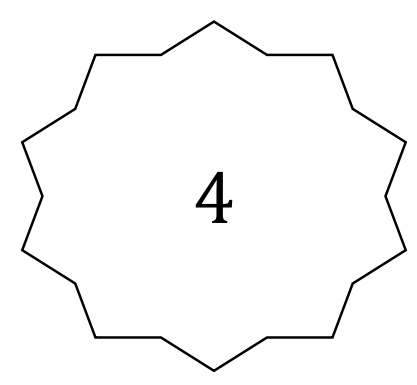

\section{A concepção de uma escola inovadora}

A construção deste capítulo se apoia no discurso de diversos agentes escolares e na utilização de documentos institucionais, para narrar a origem e o desenvolvimento da Escola Projeto Âncora. Apresento aqui um pouco dos bastidores, esforços e percalços para a criação de uma escola com práticas educacionais inovadoras. Digo "um pouco" porque não é minha intenção destrinchar o processo de consolidação dessa instituição. Desejo apenas expor alguns acontecimentos da gênese do projeto para que seja possível criar uma conexão com suas práticas educacionais atuais. No entanto, vale ressaltar que outros trabalhos já se deram a esse esforço como, por exemplo, Quevedo (2014), Almeida (2017) e Silva (2018). 
Conto agora um pouco da história de uma escola diferente, que nasceu em 2012. Entretanto sua origem é mais remota, pois, antes de se tornar uma escola, o Projeto Âncora funcionou como uma entidade assistencial durante 17 anos. Seu nome é devido à paixão do fundador catarinense pela navegação. Uns dizem que esse nome traz uma ideia de estagnação e não combina com os objetivos da instituição. Outros, mais otimistas, acreditam que o nome é coerente, porque carrega uma ideia de mudança no sentido de sempre "levantar âncora à procura de novos mares". Independente da discussão sobre o batismo, fato é, posso afirmar, que essa é uma escola que se transforma com uma rapidez intensa. Por isso, vale a ressalva ao leitor: muitas atividades descritas neste trabalho provavelmente já terão sido alteradas. O próprio panfleto de divulgação da escola se encarrega do alerta: "se você conhece o Âncora, a dica é ir revisitar, já não somos mais os mesmos. Nossa reinvenção é diária”.

Seguindo a recomendação do anúncio, revisitei a escola inúmeras vezes ao longo do ano de 2018. Dessa forma, conheci um pouco mais não só da escola, como também do seu entorno. O Âncora está localizado no município de Cotia, zona oeste da Grande São Paulo, local de antigas chácaras e de condomínios fechados de classe média alta que contrastam com a presença massiva dos barracos de famílias em situação de alta vulnerabilidade social. A região, atualmente, conta com aproximadamente 250 mil habitantes e registra um dos cem melhores Índices de Desenvolvimento Humano do estado de São Paulo (IBGE, 2019). Conta também com alguns postos de saúde, comércios de pequeno porte e shopping centers de luxo. No aspecto religioso a comunidade é privilegiada: por ali há diversas igrejas católicas e protestantes, casas espíritas e terreiros de umbanda. Coexistem nesse espaço, predominantemente urbano, 194 unidades escolares, que atendem a mais de 40 mil estudantes (INEP, 2019).

A Escola Projeto Âncora é mais uma presente nesse contexto. Conforme dito acima, no início a instituição oferecia atividades na área de cultura, esportes e lazer para as crianças da região, apenas no contraturno escolar. Segundo sua esposa, o fundador, filho de austríacos, sempre dizia que quando se aposentasse "iria devolver para o país [Brasil] tudo que sua família havia recebido". Aos 55 anos, o empresário do setor de turismo cumpriu a promessa: vendeu a empresa e utilizou o dinheiro para fundar o Âncora. A pressa era tanta que em apenas um ano o local já estava de pé. Mesmo com o sonho realizado, após um período o casal percebeu que era importante oferecer condições para que as crianças pudessem permanecer na entidade em tempo integral. Para tal objetivo, desejavam construir uma escola. Ao questionar a fundadora 
acerca dessa inquietação, ela disse que antes de o projeto virar uma escola eles "estavam enxugando gelo", porque trabalhavam de uma forma no Âncora e a escola de origem das crianças operava de outra. Essa insatisfação pode ser vista claramente no trecho retirado de uma Carta mensal publicada pelo projeto, de junho de 2011, às vésperas do registro na Diretoria Regional de Ensino em Carapicuíba (portaria nº 1067/00016/2011).

\begin{abstract}
Por que uma escola no Projeto Âncora? Para educar integralmente a criança e o jovem numa escola de qualidade a que todos têm direito. Para dar o exemplo e ser referencial. Frequentando o Projeto Âncora das $8 \mathrm{~h}$ às $17 \mathrm{~h}$, essa criança não precisará mais se deslocar entre casa, escola, casa e entidade; aqui ela receberá três refeições diárias e saudáveis tendo reflexos imediatos na saúde; além do currículo obrigatório, a criança receberá formação na área de esporte e arte, que sabemos ser fundamental para sua formação humanística; estará num espaço de muito verde, seguro e de qualidade física; será educada num método aprovado internacionalmente para que seja um ser humano feliz, solidário, cidadão e dominando os conteúdos para que possa ser um profissional competente no futuro. Mais que isso, a participação de pais será muito maior e assim a influência da entidade na comunidade tenderá a crescer e promover mudanças. (PROJETO ÂNCORA, 2011).
\end{abstract}

O novo sonho do casal foi concretizado apenas em 2012, mas, dessa vez, apenas com a presença de uma das partes, pois o empresário faleceu. Ou então, como me disseram alguns estudantes mais poéticos, "ele morreu e renasceu como escola". Após sua dedicação de 16 anos ao projeto, suas cinzas foram espalhadas sob um pau-brasil localizado dentro da própria instituição. Uma estudante me contou que a cachorrinha do fundador, chamada Tila, também foi enterrada no mesmo local e, por isso, segundo a criança, ele "virou natureza e está se divertindo" com o seu animal de estimação. No entanto, apesar da sua ausência na inauguração, ele conseguiu participar ativamente da trajetória de ampliar a atuação da ONG para uma escola de ensino formal. Frequentou vários eventos pedagógicos e se reuniu com alguns intelectuais como Rubem Alves, Mário Sérgio Cortella, Frei Betto e José Pacheco, o educador português que alterou definitivamente o rumo das coisas.

O casal precursor só tomou conhecimento da existência desse professor lusitano após a leitura do livro A escola que sempre sonhei sem imaginar que pudesse existir, publicado em 2001 por Rubem Alves. No texto, o autor descreve as experiências educacionais inovadoras vivenciadas durante sua visita à Escola da Ponte ${ }^{5}$, local onde José Pacheco trabalhou durante 
30 anos antes de se aposentar e vir para o Brasil. O contato com essa história de transformação da escola portuguesa fez com que os fundadores constatassem que o modelo das escolas brasileiras, segundo eles, "estava falido, ultrapassado e com data de validade vencida". E, por esse motivo, teriam que encontrar um meio de construir "um outro tipo de escola", que educasse para a "modificação das injustiças sociais". Segundo eles, uma escola ideal teria que educar para a cidadania e para o pensar autônomo, "uma escola feita com e para a criança". A Escola da Ponte representava essa possibilidade para os fundadores, algo que pode ser notado no trecho de uma Carta mensal divulgada em junho de 2003:

Isso existe na Escola da Ponte, então é possível também entre nós, em Cotia. Queremos terminar o ano com esta reflexão que certamente dará frutos para os próximos anos. E queremos mostrar a você o quanto somos dinâmicos e o quanto queremos de fato fazer acontecer mudanças que tornem mais justa e fraterna a vida neste país, neste planeta (PROJETO ÂNCORA, 2003).

Após alguns anos e várias conversas através de e-mails, José Pacheco, que já estava assessorando alguns projetos em território brasileiro, resolveu aceitar o convite do casal, em 2011, para orientá-los na construção da escola. Um motivo que facilitou a anuição foi a opção do professor português, que, após andar franciscanamente pelo país, se instalou na cidade de Cotia. Como esse acordo adveio, por coincidência, duas semanas antes do falecimento do fundador, os esforços em dar continuidade ao desenvolvimento do trabalho se duplicaram: disse a fundadora que "muita gente resolveu se unir em solidariedade à memória do fundador" e que "assumiram com muita vontade a incumbência de dar continuidade ao sonho de construção de uma nova escola”. O fundador parecia antever essa situação, pois antes de falecer lançou o seguinte informe: "vamos precisar de muito mais âncoras a partir do ano que vem quando iremos inaugurar a ousada Escola Projeto Âncora, que já está atraindo muitos novos âncoras que, juntos, idealizarão a escola dos sonhos". Assim como Pacheco também revelou, "a escola nasceu primeiro pelo sonho de um homem e depois pelo sonho de muitos".

Nessa continuidade, oficialmente, no ano de 2012, surge a Escola Projeto Âncora. O espaço continuava praticamente o mesmo, mas agora era preciso romper com uma tradição assistencial, que havia beneficiado mais de 6 mil crianças desde 1995, para chegar a uma outra forma de relação com a comunidade. Coragem, com certeza, não seria o elemento ausente para mudar essa atuação. Até porque, quando decidiram mudar, a ONG já gozava de certo prestígio social. Para se ter uma ideia, em 2008, em razão da comemoração dos 60 anos de existência da Declaração Universal dos Direitos Humanos, a Organização das Nações Unidas convidou o 
artista plástico Richard Hillinger para criar trinta pombas de bronze simbolizando os trinta artigos da Declaração. Cada pomba foi oferecida a uma instituição ou pessoa que prestasse serviços relevantes para a promoção da paz na humanidade. Os artefatos passaram pelas mãos de líderes como Barack Obama, Papa Bento XVI, Nelson Mandela e Dalai Lama, e por locais como o Parlamento Europeu, Anistia Internacional e Lar Neve Hanna. Uma dessas pombas pousou no Brasil e foi ofertada ao Projeto Âncora. Como esse é um prêmio itinerante, um educador me contou que a pomba ainda está no Âncora "à procura de outro projeto para presentear".

A entidade se tornava escola mas, como disse a fundadora, "não pensavam em fazer qualquer escola: o desejo era criar uma educação diferente". Segundo ela, "a Escola da Ponte foi a inspiração, mas não o modelo". Até mesmo porque as críticas do casal fundador em relação ao que chamavam de educação tradicional foram sempre incisivas e anteriores ao conhecimento dos mesmos sobre a Escola da Ponte. As práticas negativas da educação nacional foram denunciadas por eles muitas vezes em diversos informes institucionais, como se pode notar no fragmento abaixo, de abril de 2013:

\footnotetext{
[...] a escola tradicional é um espaço que privilegia o não aprendizado do mundo e da vida. Pois este tipo de escola tira as crianças do mundo, da realidade onde vivem e as confina num prédio, numa sala fechada, por vezes com grades, e lá dentro um professor dá aulas de 50 minutos sobre assuntos que, na maioria das vezes, não servem para a vida e para o mundo. [...] A escola tem mantido a sociedade afastada dos problemas do dia a dia, de suas razões e longe das soluções que poderiam ser construídas em conjunto. As crianças aprendem a tabela periódica, mas não aprendem a fazer arroz; aprendem sobre a corrente sanguínea, mas não sobre como curar uma ferida; aprendem sobre os ventos e as marés, mas não fazem a menor ideia do que fazer numa situação de catástrofe. Temos que sair do confinamento da sala de aula e da tutela de um professor. O papel do professor, tão desvalorizado e mal remunerado, precisa tomar a sua verdadeira dimensão. (PROJETO ÂNCORA, 2013)
}

Cientes do tipo de escola que não queriam, agora era preciso focar em um modelo alternativo. Para isso contrataram e reuniram professores, funcionários e voluntários que, segundo José Pacheco, “entenderam que manter o modelo educacional do século XIX não era mais possível". O único pré-requisito adotado para trabalhar na instituição foi a boa vontade para mudar. Nenhum tipo de formação específica ou "experiência em escolas alternativas" foi exigido. Não havia necessidade nem de conhecer o discurso dos teóricos do construtivismo, pois, ainda nas palavras de Pacheco, "não estavam procurando fofoqueiros". Claro que essa fala irônica do educador português não representa a ausência total da adoção de teorias no processo educativo: apenas retrata a importância dada por ele à prática escolar cotidiana em detrimento 
de um modelo teórico previamente estabelecido. Se não for esse o motivo, seria difícil explicar que todos os projetos assessorados por ele aqui no Brasil possuam um referencial teórico - aliás, um multirreferencial teórico, composto apenas por brasileiros.

Antes da alcunha de ufanista, ele se defende dizendo que é uma "questão de bom senso", onde em vez de "ler um Piaget vamos ler o Lauro de Oliveira, invés de ler John Dewey vamos ler o Anísio Teixeira, invés de ler Claparèad vamos ler o Lourenço Filho”. Segundo ele, esses autores nacionais reinterpretaram os autores estrangeiros para uma versão brasileira. Ele também quis se livrar de outro julgamento antecipado, o de colonizador, ao dizer que "resolveu esquecer a Ponte" e, sexagenário, voltar à escola "para ver uma educação feita por brasileiros, sem o mínimo contributo da Ponte, romper com a educação tradicional”.

Outra questão que pude perceber, quando entrevistei aqueles que participaram dos primórdios da escola, foi a crença unânime na inovação como algo que aporta melhoria na educação. A pessoa que ocupa a coordenação atualmente afirmou que "inovação é tudo aquilo que apresenta caminhos melhores ao modelo educacional vigente”. A própria fundadora acredita que a inovação educacional é uma "proposta contemporânea de transformação da escola que busca torná-la um espaço para formação de indivíduos capazes de realizar seus projetos de vida". Alguns educadores do projeto enxergam a inovação como algo que possibilita a vivência dos educandos em um ambiente mais democrático. José Pacheco, apesar de também corroborar com essa perspectiva, é um pouco mais radical e declara que "inovação é tudo aquilo que é inédito, logo não é inovação melhorar a aula, pois ela não pode ser melhorada e sim erradicada".

Imbuído dessa crença do "fazer diferente", José Pacheco contou que se reuniu com os professores do Âncora apenas uma semana antes de começar a transição para se tornar uma escola. Quando chegou na sala onde todos estavam reunidos, segundo ele, "havia um pânico generalizado na turma de educadores". Todos estavam com um papel sobre a mesa esperando que ele dissesse algo relevante para a formação de professores. Ao perceber essa ansiedade, Pacheco disse: "escrevam nessa folha os valores que comandam a vida de vocês". Olharam para ele apreensivos e questionaram o motivo daquilo. Ele emendou: "escolas são pessoas e pessoas possuem valores que comandam a vida de vocês. Por isso, quero saber se existem valores comuns entre vocês". Todos escreveram, ele recolheu os papéis e quando olhou percebeu que havia cinco valores presentes em todos as folhas: afetividade, honestidade, respeito, 
responsabilidade e solidariedade. Dessa forma, José Pacheco concluiu com uma indagação: "se estes são os valores, quais serão as práticas educacionais compatíveis com eles?”.

Os valores obtidos nesse encontro embrionário tornaram-se os principais norteadores das finalidades educativas da escola. Estão presentes até hoje, grafados nos muros da instituição, e na ponta da língua de toda a comunidade escolar. Qualquer um que conhece e participa do projeto, conforme relatou uma estudante, "tem que saber e praticar os valores de cor e salteado". São os verdadeiros pilares da instituição, pois a partir deles é que foram criados todos os outros documentos que regem os princípios da organização. São tão importantes que servem até mesmo para pautar a conduta dos diversos agentes no cotidiano escolar. Percebo aqui a diferença crucial ao comparar o nascimento da Escola Projeto Âncora com aquilo que é costumeiramente praticado nas demais: seu planejamento inicial se deu a partir de uma atividade coletiva de pessoas envolvidas com o processo e não de um ato individual e isolado.

Nesse sentido, vale dar crédito ao assessor português pela confiança depositada no trabalho cooperativo dos professores. Relata Pacheco que, quando começou a acompanhar o Âncora, os professores estavam preocupados em "obter uma formação específica para fazer o projeto acontecer" e que ele foi contra essa opção. Quando os educadores diziam "nós só sabemos fazer aquilo que nos ensinaram na faculdade", ele retrucava: "que ótimo, pois a ideia não é jogar ninguém fora, mas sim aproveitar a pessoa como ela é e dar as condições de transformação". Para o lusitano, "o Brasil tem os professores certos que trabalham de um modo errado" e, por isso, "é preciso dar tempo às pessoas e oferecer possibilidades para que elas se modifiquem". Talvez essa crença de Pacheco tenha a ver com a sua própria experiência docente, conforme exposto no relato a seguir:

Fiquei durante sete anos dando aula segundo as práticas tradicionais de ensino e no final de cada ano eu me questionava: por que ensino tão bem em cada aula e há sempre alguns alunos que não aprendem. Então cheguei a um momento que fui obrigado a refletir que, se eu dava aula e eles não aprendiam, logo, eles não aprendiam porque eu dava aula. Quando cheguei na Escola da Ponte, encontrei duas pessoas com as mesmas inquietações e aí tudo começou... (informação pessoal)

Embora confiantes nos conselhos dados pelo assessor português e com um enorme desejo de mudança, os professores tiveram que enfrentar as próprias inseguranças e as dificuldades iniciais de qualquer projeto que pretende fazer algo diferente. Sobre o princípio de seu trabalho na instituição, uma educadora que já trabalhava no Âncora antes da transição 
confessou que estava de posse de um medo enorme, porque "estava prestes a fazer algo fora do comum". Educação, para ela, sempre foi algo "dentro dos moldes convencionais, mais certinho e com muita disciplina". Quando descobriu que um dos acordos era o de que "todo mundo deveria ser responsável pelo aprendizado da criança" independente da sua área de especialização, os pensamentos negativos povoaram a mente da educadora: "como assim? Não sei trabalhar com esporte, minha área é outra, não sei trabalhar com a criançada ao ar livre, não vou dar conta". Felizmente, com o tempo, ela disse que foi começando a entender e aprender cada vez mais e, assim, podia ver "os primeiros frutos do trabalho se desenhando", a partir do retorno positivo das crianças.

Outro educador, que também presenciou esse momento de transição, relatou que o primeiro ano foi extremamente difícil porque ele teve dificuldade para entender qual era de fato o seu papel de professor ali naquele espaço. No entanto, não estava tão preocupado quanto a maioria dos seus colegas, pois entendia que "nenhuma transformação é tudo bem, tudo tranquilo". Para ele, a resistência à mudança é algo "natural do ser humano", por isso "não pensava, em nenhum momento, retroceder e nem desistir da empreitada". Assim, confiou "que todos os seus anseios iriam se diluir com o passar do tempo".

Identifico, nessas declarações, aspectos emocionais extremamente significativos que permitem a constatação das repulsas, medos e resistências acerca daquilo que é diferente, novo ou desconhecido. O modo como costumeiramente se constitui a trajetória educacional de uma pessoa na maioria das escolas é permeado por instruções que seguem um roteiro rígido daquilo que é certo ou errado em matéria de aprendizagem. Geralmente, são recomendações do tipo: "se quiser aprender melhor, precisa ler e decorar isto", "precisa escrever com estas palavras", "precisa realizar esses exercícios do livro x", "precisa obter a nota máxima", e assim por diante. Isso faz com que certas condutas fiquem internalizadas e reflitam no modo de agir do futuro adulto que deseja se tornar um professor. Condutas tão difíceis de serem rompidas que se mantêm intactas mesmo após o término do ensino superior, que, muitas vezes, auxilia na reprodução das mesmas. Por isso, creio que as desconstruções das práticas docentes, conforme foi afirmado pelos educadores acima, sejam tão penosas.

Sigo a narrativa, para melhor entendimento desse momento que configurou o início da Escola Projeto Âncora, com a descrição da chegada das primeiras crianças. Algumas já frequentavam o projeto no contraturno escolar, mas outras foram convidadas, totalizando 180 
crianças. O convite para participar do projeto possuía alguns pré-requisitos: residir em um raio de até três quilômetros da escola, ter uma renda de no máximo três salários mínimos, inscreverse no serviço municipal de assistência social e possuir idade correspondente aos níveis de Educação Infantil e Ensino Fundamental I. Isso porque a escola está até hoje dentro de uma ONG que possui um trabalho de assistência social. Nesse momento, ficou decidido entre os educadores que o trabalho deveria ser focado no desenvolvimento de atitudes em vez de conteúdos. Um educador contou que foi difícil sustentar essa decisão diante da cobrança das famílias por "atividades no caderno ou lições de casa". Segundo ele, após uns três meses de trabalho "a preocupação das famílias só aumentava" e os professores tinham que explicar: "veja bem, se nós não desenvolvermos o aspecto atitudinal não tem aprendizagem, o esforço será inútil. É necessário trabalharmos com eles alguns valores. Não serve para nada um caderno repleto de informações copiadas".

Apesar da paciência em conscientizar os familiares, o resultado não estava sendo muito positivo, pois, ao mesmo tempo em que os professores intensificavam os esforços para desconstruir certas crenças pedagógicas junto às crianças e familiares, precisavam fazer o mesmo com suas próprias práticas docentes. $\mathrm{O}$ consolo residia no trabalho em equipe, onde "cada um auxiliava o outro para dar conta do recado, sem muita pressa". As famílias sempre tiveram acesso irrestrito à escola, a qualquer hora do dia, mas os educadores acharam necessário uma reunião para escutar as necessidades e responder aos anseios da coletividade.

Esse primeiro encontro ocorreu no ginásio da escola, que quase não conseguiu acomodar os presentes. O barulho que antecedia a reunião "era ensurdecedor", conforme contou uma das educadoras, até que "houve um momento mágico", as crianças com as mãos levantadas pediram silêncio aos pais. Esse gesto, que pode parecer algo sem relevância, foi visto por todos os educadores como o resultado da persistência de uma atitude orientada e exemplificada por eles na relação com as crianças. Segundo a educadora, "naquele momento, tudo começou a fazer sentido. Vimos que elas começaram a entender o que era uma atitude apoiada por um valor. Foi um combustível. Estávamos precisando daquilo”. Após a alegria dos educadores presentes e o silêncio dos pais, a reunião seguiu e puderam discutir sobre os objetivos da escola, sobre os diferentes métodos de aprendizagem, sobre dispositivos para melhorar a comunicação entre a comunidade escolar, entre outros assuntos. O desfecho do encontro, segundo a educadora, "foi satisfatório": a partir dali, "as famílias abraçaram a proposta de uma educação diferente e se dispuseram a participar cada vez mais do projeto". Houve também as famílias 
desistentes que optaram por "não abraçar a causa". Alguns pais disseram "que era muita loucura" e que preferiam matricular seus filhos em "escolas normais".

Chamo a atenção para a persistência desses educadores ao sustentarem ideias educativas diferentes daquelas que são costumeiras no âmbito escolar. Ideias que não fizeram parte sequer de suas próprias trajetórias profissionais anteriores ao Âncora. Parece que a confiança da escola como um espaço autônomo ajudou bastante nesse processo. Intitulam-se, até hoje, como uma "escola particular gratuita" que deseja ser uma "escola pública autônoma". Acreditam que a autonomia é construída e não se chega a ela sem se passar por ela. Por isso, para fazer escolhas, as crianças precisam saber que estas geram responsabilidades. Difícil encontrar um corpo docente que não prioriza a escola como local de acúmulo de conteúdos teóricos. Apesar do discurso geralmente defendido nos Projetos Político-Pedagógicos, sobre a formação de cidadãos capazes de agir e compreender o mundo em que vivem, a maioria das práticas educacionais presentes nas escolas caminha na direção oposta. Parece que o desenvolvimento de habilidades necessárias para se viver em sociedade é colocado em segundo plano, privilegiando apenas o lado cognitivo.

Uma situação bastante ilustrativa para o fato constatado acima foi quando alguns educadores resolveram ensinar para as crianças a maneira correta de circular pelos diferentes espaços da escola sem incomodar os colegas dedicados a atividades que exigiam uma maior concentração. Um educador que participou dessa atividade contou que foi preciso repetir exaustivamente frases como "não é necessário correr trombando em todos colegas no caminho" ou então "se vocês subirem as escadas dessa forma destrambelhada irão se machucar". Essas instruções não eram colocadas como ordens, e sim como ações praticadas em conjunto, onde o "educador e o educando compartilhavam de um mesmo combinado". Houve momentos, ainda segundo o professor entrevistado, em que foi possível notar "alunos que já haviam interiorizado a forma responsável de se caminhar e passaram a corrigir alguns professores". A relação de aprendizagem entre os próprios estudantes, para se chegar a um acordo de convivência, também ocorreu em diversos episódios, conforme conta um estudante que presenciou esse momento:

A gente corria em todos os espaços. A gente entrava nas salas correndo e fazendo muito barulho. Depois de um tempo, a gente foi entendendo que aquilo atrapalhava muito as outras pessoas. Não era legal. Eu mesmo comecei a cobrar dos meus amigos. Os professores perguntavam sempre: "e aí pessoal, o que vocês acham da maneira que as pessoas estão circulando pela escola?". Tinha gente que mentia dizendo que estava tudo certo. Eu falava a verdade: ainda está muito ruim, tem gente gritando, empurrando, quebrando coisas. Aí os professores me orientavam dizendo: "se você já 
sabe identificar que seus amigos não estão cumprindo os combinados, então conversa com eles". Comecei a chamar meus colegas de canto e dizer: "isso não é bom, faça assim, respeite o combinado, vamos melhorar nossa escola". Outros colegas fizeram a mesma coisa que eu também, e aí depois de um tempo todo mundo entendeu que era importante valorizar a escola e deu tudo certo. (informação pessoal)

Outro educador também contou que, durante esse período inicial da escola, já chegou a ficar cerca de 40 minutos com a mão levantada esperando o silêncio das crianças. Levantar a mão era o gesto combinado entre todos eles para solicitar a palavra ou pedir silêncio. Segundo ele, realizar esse ato extremo foi "muito importante", porque sabia que "somente com paciência conseguiria construir uma boa base de atitudes e valores junto com os estudantes". Não só isso, como também serviu para continuar insistindo e manifestando a ideia de que "qualquer lugar poderia ser um espaço de aprendizagem”. Portanto, noto nesse acontecimento a presença constante de uma reeducação profissional que tem como característica principal a desconstrução de certas condutas e paradigmas que todos esses educadores reconheceram a necessidade e, assim, foram guiados pela convicção de que não se ensina aquilo que se sabe, mas aquilo que se é. Creio que essa reeducação somente se tornou possível graças aos valores coletivos acordados naquela reunião inicial, que guiam as relações humanas dentro da escola. Por consequência, anulou-se qualquer probabilidade de ações isoladas desses educadores, como é bastante comum em grande parte das escolas.

Num segundo momento desse período de constituição da escola, tornou-se necessária a criação de estruturas básicas para receber os conteúdos curriculares. Para tal, os educadores tiveram que pensar em um tipo de organização das crianças. Não queriam uma divisão baseada em séries ou faixa etária, pois acreditavam na possibilidade da convivência de diferentes idades em uma mesma etapa do processo de aprendizagem. De fato, não estavam procurando uma divisão das crianças: desejavam apenas "facilitar o planejamento e o desenvolvimento do trabalho pedagógico", conforme relatou uma educadora. A primeira organização se deu a partir de quatro cores. Cada cor representava um grupo de aproximadamente quarenta crianças. Cada grupo tinha quatro educadores responsáveis. A mesma educadora seguiu contando que essa primeira forma de organização "durou pouco tempo" e foi importante apenas para realizar um "diagnóstico individual mais apurado de cada criança".

A segunda tentativa durou um pouco mais de tempo. Consistiu na formação de grupos baseados em uma escala numérica de 1 a 3 para classificar o nível de autonomia de cada criança. O número 1 significava que a criança estava ciente das suas responsabilidades perante a escola 
e tinha uma facilidade maior em ajudar os outros. O número 2 representava a criança que apesar de ter ciência das suas tarefas ainda necessitava desenvolver alguns meios para lidar com a própria aprendizagem. $\mathrm{O}$ número 3 identificava a criança que possuía uma grande dificuldade em se relacionar com seus amigos e respeitar os acordos estabelecidos. Assim, as crianças foram classificadas segundo cada nível e separadas em grupos compostos por cinco participantes. Ficou decidido que os grupos iriam conter duas crianças de nível 1, duas crianças de nível 2 e uma criança de nível 3. Nenhuma criança ficou sabendo sobre o significado acerca do seu número, segundo um educador, "porque isso não ajudaria em nada, serviria apenas para segregar, e a nossa proposta sempre foi a de integrar". Informou também o mesmo educador que os estudantes tinham a possibilidade de transitar entre os diferentes níveis e que a "mudança de classificação não representava uma progressão", significava simplesmente "a identificação de um momento do desenvolvimento de cada criança”.

Logo após essa fase, que um educador apelidou carinhosamente de "gênese do furacão", começaram a notar que os estudantes estavam prontos para serem apresentados aos conteúdos curriculares das disciplinas. Contudo, como era de se esperar, não optaram pelo modelo comum que se caracteriza por aulas expositivas de 50 minutos lecionadas individualmente por um professor dentro de uma sala. Fizeram diferente. Primeiro, decidiram que a escola funcionaria das $8 \mathrm{~h} 00$ às $16 \mathrm{~h} 20$ com a possibilidade de horários alternativos de entrada e saída para quem solicitasse. Isso foi pensado para respeitar as necessidades individuais de cada criança como, por exemplo, a distância entre sua casa e a instituição. Depois disso, apresentaram para as crianças as atividades ofertadas pela escola e pediram para que cada um confeccionasse um cronograma a partir dos seus próprios desejos. Tinha atividade para todos os gostos, desde as mais comuns como matemática e português até as oficinas de circo e artesanato. Feito isso, cada criança tinha que respeitar seu próprio planejamento cotidiano de atividades. O único horário comum a todos era o horário da refeição.

Sobre essa liberdade do estudante na definição do que fazer durante o período escolar, uma professora relatou que inicialmente "foi uma baita confusão. Tinha aluno que copiava o planejamento do outro. A maioria não cumpria com os horários". No entanto, estavam cientes disso, "pois lidar com a liberdade não é fácil mesmo". Outro professor, apesar de concordar com esse discurso da colega, disse que "foi ótimo essa bagunça inicial, pois percebia que as crianças estavam aprendendo a lidar com o aproveitamento do tempo". Isso é algo que, segundo ele, “até mesmo os próprios professores, que são adultos, não possuem muita facilidade. E não 
tem nem como cobrar alguma coisa, porque não fomos educados para isso". Um terceiro educador relatou outro acontecimento dessa fase. Disse que foi extremamente complicado para os professores, inclusive para ele, "aprender a lidar com as escolhas dos estudantes e, em vez de forçar a barra para corrigir um ato equivocado do aluno, tinham que desenvolver a capacidade de argumentação". O professor continuou dizendo: "cansei de ver aluno que reservava no planejamento, sei lá, três horas para brincar ou duas horas para algo que não exigiria tudo isso. Aí tinha que explicar, argumentar o porquê de fazer diferente. Foi tenso!"”.

Ainda dentro dessa lógica, independente da área de especialização, definiu-se que todos os professores seriam considerados tutores. Atuariam apenas na orientação de projetos individuais surgidos pelas diferentes inclinações dos estudantes. O educador que conhecia muito bem uma determinada área seria chamado também de especialista. Havia assim o especialista em geografia, em português, em matemática, em educação física, em química, em biologia, entre outros. Relato um exemplo presenciado, para que se entenda melhor essa nova postura docente que estava sendo exigida. Observei um especialista de matemática sendo procurado por algumas crianças que estavam desenvolvendo um projeto sobre línguas estrangeiras. Primeiro, procuraram um educador especialista na área de português para entenderem quais eram os idiomas falados no Brasil além da língua portuguesa. Depois, foram atrás de um educador especialista em matemática para aprenderem a questão da porcentagem e, assim, determinarem a distribuição espacial de falantes de algumas línguas.

Sendo ainda mais fiel a esse momento, trago outra questão acordada: não só os professores seriam responsáveis pela aprendizagem das crianças. A cozinheira faria a comida, mas seria vista como a educadora da alimentação. O jardineiro cuidaria da grama, mas seria visto como educador paisagístico. Todo profissional que atuasse na escola deveria ter em mente sua obrigação com o bem-estar, proteção e desenvolvimento da criança nos âmbitos mais diversos. Nem todo mundo gostou dessa história, conforme confessou a coordenadora do projeto: "tivemos educadores que não deram conta e pediram para sair. Diziam que aquilo estava além das suas possibilidades. Diziam que gostavam de dar aula e ainda não estavam prontos para abandonar essa postura". Aqueles educadores que resolveram ficar e aceitar o desafio contaram que com o passar do tempo as coisas "foram se encaminhando" até chegar à organização atual, que será detalhada no próximo capítulo. Já para tentar compreender o motivo dos educadores que resolveram sair, talvez a explicação de Pacheco seja suficiente: 
O modo como o professor aprende é o modo como o professor ensina. Quando os futuros professores chegarem nas escolas, reproduzirão esse modelo. Não vão entender que existem outros modos de se fazer. Lamento que as grandes universidades não tenham despertado para a necessidade de mudar. Costumo dizer que se um doutorado em Vygotski continua dando aulas, das duas uma: ou não leu o Vygotski, que eu li, ou é um analfabeto funcional que lê e não entende. É impossível estudar métodos ativos e continuar fazendo a mesma coisa. (informação pessoal)

Para finalizar este capítulo, vale evidenciar os meios pelo qual a instituição conseguiu se manter financeiramente todos estes anos. No que diz respeito à fase inicial de construção, o fundador não aceitou nenhum tipo de doação. Segundo sua esposa, apesar das ofertas de alguns amigos empresários, ele sempre recusava dizendo que "iria edificar com o próprio dinheiro, da forma que desejava e com o melhor material de construção possível". No entanto, no que concerne à permanência do projeto, a história foi bem diferente. Contou com um conjunto de aproximadamente 160 pessoas físicas e jurídicas. Esse grupo contribui até hoje com a entidade, especialmente no tocante à criação de estratégias para captação de novos recursos. Outra forma de captação advém da autorização do Conselho Municipal dos Direitos da Criança e do Adolescente para angariar fundos dedutíveis do Imposto de Renda devido. Isso significa que parte do imposto pode ser aplicada diretamente em benefício de uma causa, mecanismo pelo qual se pode deduzir até $1 \%$ de pessoas jurídicas e até $6 \%$ de pessoas físicas.

Além dessas formas de apoio, o Âncora foi desenvolvendo, no decorrer dos anos, programas próprios para geração de renda, como, por exemplo, a produção e venda de mosaicos, artesanatos e roupas. Essa ação foi acordada na reunião do conselho em 2017. A ideia era fomentar uma sustentabilidade financeira fundamentada, principalmente, nas atividades da escola, diminuindo cada vez mais a dependência das doações externas. Quando lá estive, pude presenciar essa intenção se transformando em ação por parte dos estudantes. Alguns estudantes se interessaram pela compra de uniformes para os times de futebol formados na escola. Para tal objetivo, procuraram um tutor especialista em matemática e aprenderam a fazer cotação de preços. Entraram em contato com diversas lojas esportivas, e o melhor valor encontrado pelo conjunto de uniformes foi de R $\$ 1.000$. Descobriram, após procurarem o setor financeiro da instituição, que não havia dinheiro sobrando para comprar os trajes. Dessa forma, resolveram buscar os familiares na tentativa de arrecadar o valor necessário. Contabilizaram a quantidade de pais que faziam parte da escola, fizeram a multiplicação e solicitaram $\mathrm{R} \$ 5$ de cada um. Os uniformes foram adquiridos. A captação de recursos foi um sucesso e acabou inspirando seus colegas na organização de outras arrecadações. Inspirou até mesmo um discurso da fundadora que, ainda sob o efeito do entusiasmo perante essa ação coletiva, ressaltou sua convicção de 
que somente através da educação seria possível conseguir "um outro país, muito mais humano". Entretanto, "esse ser humano será mais colaborativo". E o objetivo seria "que o exemplo do que foi feito aqui vire política pública”.

Para compreender como se organiza o plano da gestão financeira da escola, é preciso conhecer três órgãos escolares e suas respectivas responsabilidades nessa área. São eles: Conselho de Projeto, Conselho de Direção e Associação de Pais. O primeiro órgão é formado pelo diretor, pelos coordenadores e por todos os educadores. É responsável pela supervisão das instalações, equipamentos e outros recursos didáticos. Cabe a este também definir os prérequisitos para o recrutamento interno e externo de profissionais, nos termos presentes do regimento escolar. O segundo é responsável por questões como aprovação do orçamento anual, concessão de pagamentos, produção do relatório de posição de contas e verificação e atualização de patrimônios. Esse órgão é composto por um líder comunitário, pelo presidente(a) da Associação de Pais, pelo diretor(a) e por quatro coordenadores(as $)^{6}$. O terceiro e último órgão é constituído pelos responsáveis dos estudantes matriculados no Âncora e é encarregado da resolução dos impasses que não encontrem respostas nas demais estruturas de decisão da escola.

As decisões tomadas na instituição, seja no plano financeiro, no pedagógico ou em qualquer outro tipo de segmento, sempre são discutidas, de forma participativa, nas assembleias escolares. Há assembleias de pais, de alunos e de educadores, conforme serão descritas de forma minuciosa no próximo capítulo. Existem também outros mecanismos similares na escola que servem para estimular a participação e o diálogo entre as pessoas. Isso é assegurado, inclusive, em um dos artigos do regimento escolar que trata da criação de dispositivos que possam garantir a participação de todos nas decisões da instituição. Uma coordenadora disse que a opção por uma "gestão mais horizontal" da escola talvez tenha sido fruto de um discurso que o professor Pacheco realizou em uma das suas primeiras visitas ao projeto. Declarou o assessor português que "a transformação jamais viria de cima, dos governantes, e sim da base, do chão da escola, e que, para isso, precisávamos exercitar a nossa inerente capacidade brasileira de sermos cooperativos".

$6 \mathrm{O}$ mandato dos integrantes possui a duração de um ano letivo. 
Hoje em dia, a mesma coordenadora confessou que aquele sonho enunciado por José Pacheco foi concretizado e que agora a segunda missão é "fazer com que o Âncora possa contribuir e inspirar o maior número de escolas ou iniciativas educacionais. Que elas tenham nosso apoio e nossa consultoria para que façam o melhor para cada instituição". A opinião da fundadora também segue dentro dessa essência. Em uma das entrevistas, ela revelou que a Escola Projeto Âncora "é o resultado de um grupo que cansou de depositar sua fé na classe política para a resolução de seus problemas" e que resolveu "se organizar para buscar o que precisa e tem direito". Se depender dos números apresentados pela instituição, o objetivo já foi atingido. O Âncora já foi citado mais de 6 mil vezes nas diferentes redes sociais, 300 vezes em sites e 325 em mídia impressa. Foi objeto de 30 trabalhos acadêmicos. Pautado por 21 programas de televisão. Visitado por mais de 15 mil pessoas de diferentes nacionalidades. Reportados em 2 documentários ${ }^{7}$. Está entre as 100 melhores ONGs do Brasil segundo o Instituto Doar. E, por fim, faz parte de uma lista mundial (InnoveEdu) que possui 96 escolas que apresentam soluções para demandas do século XXI, com curadoria em quatro países: Brasil, Estados Unidos, Reino Unido e Catar.

Acreditar no potencial transformador de um coletivo de pessoas e não se acomodar perante as injustiças sociais é algo urgente e necessário. De fato, é imprescindível a presença dessa autoestima no discurso dos entrevistados, ainda mais quando aquilo que se quer fazer é diferente do que se apresenta ao redor. Confio na boa vontade do "fazer diferente", tão almejado por essas pessoas. Pode parecer, algumas vezes, que seguem por uma via utópica, mas a lucidez é muito mais presente. Lucidez não pelo fato da criação ou difusão de um tipo inovador de educação. Lucidez porque demonstram respeito e preocupação com as diferentes demandas das pessoas envolvidas com a comunidade escolar. É um projeto composto por pessoas que buscam, constantemente, oferecer condições para o desenvolvimento dos diversos propósitos pessoais requeridos. Não enxergam a escola como um método replicável, mas sim como algo singular que faz parte de cada contexto, de cada lugar. Dessa forma, veremos a seguir como o Âncora consegue se afastar de algumas práticas que são costumeiras dentro de ambientes educativos. Práticas voltadas, cada vez mais, para a transmissão de um conjunto de conhecimentos alheios às reais necessidades dos indivíduos implicados no processo educacional. 


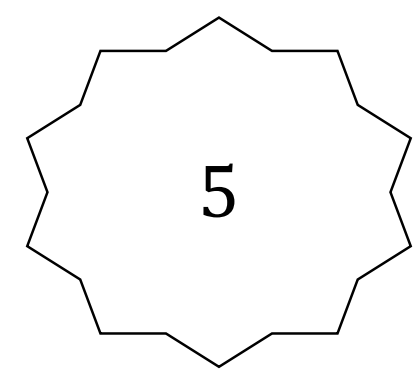

\section{Práticas educacionais}

Comparo e descrevo neste capítulo o que chamo de práticas educacionais costumeiras e práticas educacionais inovadoras. Inovação é um termo argucioso, atraente e equívoco ao mesmo tempo: atraente porque transmite a ideia de melhoramento e progresso, quando em verdade significa apenas algo diferente. Equívoco porque, mal utilizado, desvia o foco da essência da atividade educativa quando se restringe, por exemplo, a enfrentar problemas de ordem tecnológica nas instituições. Já as práticas costumeiras podem ser descritas como um conjunto de comportamentos comuns ou de padrões seguidos pelos membros de um determinado grupo social, que a tal se sentem obrigados.

Entendo por práticas educacionais o conjunto de atividades formativas que proporcionam as experiências necessárias para que aconteça a aprendizagem. Uma espécie de "fazer", voltado para o ato educativo. Por isso, limito minha análise, em termos pedagógicos, aos aspectos observados em campo que estão mais ligados a essa prática. São eles: o espaço escolar, os agentes educativos, as estratégias de ensino-aprendizagem e os modos de avaliação. 


\subsection{Configuração e utilização do espaço físico da escola}

A Escola Projeto Âncora está localizada no município de Cotia. Para ser mais

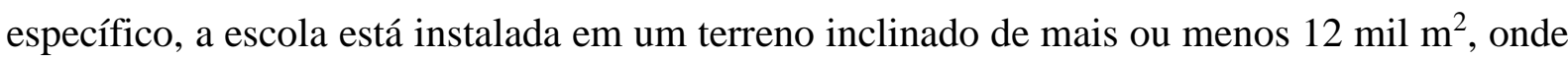
carros e pedestres possuem acesso pela mesma entrada, na Estrada Municipal Walter Steurer, número 1.239. Confesso que o deslocamento até o local a partir do meu ponto de origem, região do $\mathrm{ABCD}$, não é uma tarefa simples. São necessárias três conduções, que realizam o percurso em um tempo médio de duas horas e meia, e mais uma caminhada de aproximadamente 20 minutos para se chegar até a escola. No entanto, esse longo trajeto teve suas vantagens. Uma delas foi a possibilidade de conhecer melhor o entorno da instituição.

O município de Cotia faz parte do eixo de dilatação periférica dos grandes lotes de terra fechados, durante os anos de 1970 e 1980. Parte desse crescimento se deve à expansão dos condomínios fechados para a classe média alta, porém também pude perceber que foi significativo o crescimento desordenado das áreas mais pobres situadas dentro desse território. De fato, esse alargamento desestruturado está presente na maioria das cidades brasileiras, o que torna o acesso aos equipamentos públicos insuficiente para atender à crescente demanda dos moradores. Os efeitos disso já são de conhecimento público: violência, pobreza e exclusão social. Uma cidade atravessada por desigualdades, hierarquizada e cada vez mais verticalizada.

Na minha primeira visita ao Âncora, em fevereiro de 2018, ao descer do último ônibus e começar a caminhada rumo à instituição, parei para tomar um copo de água em um dos vários botequins presentes na região. Depois do segundo gole, a minha curiosidade fez com que eu estabelecesse a primeira conversa informal da pesquisa. Um simpático atendente que aparentava ter mais ou menos 50 anos me informou que desde criança residia nos arredores do Jardim Rebelato (bairro da Escola Projeto Âncora) e que pôde notar que, nos últimos dez anos, inúmeros prédios residenciais de padrão superior à média começaram a ser erguidos em alta velocidade, para serem ocupados sobretudo aos moradores provindos da cidade de São Paulo que estavam em busca, em suas palavras, de um "refúgio verde". A indignação do atendente do bar foi bastante sonora ao dizer: "esses prédios chiques acabaram com o nosso sol”, referindose ao ofuscamento da luz solar causado pelas construções. Mais tarde, com novas observações e novas conversas, pude entender melhor sua revolta legítima. $\mathrm{O}$ fato relatado pelo cordial funcionário foi desencadeado a partir do desmatamento e desocupação de antigas chácaras, o 
que deu lugar a vários condomínios fechados em meio a vilas populares. Por esse motivo, a relação entre os ocupantes da região é bastante conflituosa.

Agradecido mais pela conversa do que pelo copo de água, continuei a minha caminhada até a escola. No caminho, notei que havia uma grande quantidade de estabelecimentos comerciais como padarias, quitandas, farmácias, mercados e outras lojas de pequeno porte, porém não vi a presença de uma livraria ou de uma biblioteca sequer. Observação esta que seria confirmada mais tarde por outros moradores, que me relataram que há, de fato, uma precariedade ou até mesmo inexistência de aparelhos culturais, de lazer e de esporte na região. Confirmada também pela autêntica expressão de uma senhora que tive a oportunidade de escutar em uma parada de ônibus próxima à escola: "aqui, quem quiser fazer algo mais diferente, de lazer ou outra coisa, tem que ir pra Granja", fazendo menção a um distrito nobre vizinho.

Em meio a essa escassez que marca a região, a Escola Projeto Âncora se orgulha por ser um importante centro cultural comunitário. Festas, saraus, campeonatos esportivos, apresentações de teatro e espetáculos circenses são alguns dos exemplos de aproximação da escola com a comunidade. As crianças atendidas pela instituição provêm de famílias pobres; o projeto já acolheu mais de 6 mil crianças. A maioria dos pais e mães dessas crianças estão desempregados ou trabalhando de maneira informal. São diaristas, ajudantes da construção civil, manicures e babás que chegam a passar horas ou dias longe dos filhos, longe dos lares. Os estudantes do projeto residem principalmente nos seguintes bairros de Cotia: Recanto Suave, Cohab Raposo, Jardim Barbacena, Jardim do Engenho, Jardim da Glória, Jardim Rebelato, Jardim Sabará e Jardim Santa Maria. Em menor quantidade, há também aqueles que moram nas cidades de Carapicuíba, Embu das Artes e Osasco.

Apesar da Escola Projeto Âncora situar-se na parte mais alta de um terreno e chamar a atenção com seu muro decorado por mosaicos coloridos, o visitante desprevenido, ao chegar aos arredores da instituição pela primeira vez, pode ter dificuldades para conseguir identificar o lugar. Sei que pode parecer estranho o que vou afirmar, mas o Âncora não é uma escola com "cara de escola". Deixe-me explicar o que quero dizer com essa expressão. Costumeiramente, as escolas se assemelham a grandes gaiolas. Possuem inúmeras grades e portões para se ter acesso às salas de aula. E a própria sala de aula é um ambiente fechado, para não dizer sufocante. Geralmente, para conseguir acesso ao que chamam de sala dos professores, é necessário obter 
uma autorização que é dada após percorrer a sala da secretaria ou da direção. Às vezes a obtenção de um simples documento ou de uma simples informação acaba se transformando em uma tarefa hercúlea, dado o número de restrições a serem enfrentadas.

Para ilustrar melhor esse fato, me recordo de uma escola pública, na cidade de Diadema, onde lecionei por alguns meses. Ali, todos os professores procuravam sair com muita antecedência de suas casas, pois sabiam que, no mínimo, poderiam perder 15 minutos só para adentrarem as suas respectivas salas de aula. Isso acontecia porque a escola contava com três portões de acesso vigiados por três funcionários que, muitas vezes, não tinham sequer a posse das chaves. Lembro-me também, até hoje, da felicidade da inspetora escolar quando lhe informaram que todas as salas de aula da escola passariam a ter uma chave única. Assim, ela não precisaria mais gastar tanto tempo escolhendo a chave correta em seu vasto molho.

Por mais que esse exemplo possa parecer um pouco extremo, ao conversar com outros professores de diferentes escolas percebo que a maioria das escolas (públicas ou privadas) também opera sob essa mesma lógica de encarceramento. Não posso ser imprudente e deixar de explicar o que está por trás dessa lógica. Toda estrutura administrativa de uma escola manifesta a sua organização na esfera consciente e corresponde a outra ordem racional, determinada pelo poder público. Apesar disso, conforme aponta Cândido (1964), a estrutura total de uma escola é algo mais complexo, que compreende não só as relações reguladas conscientemente, mas, ainda, todas as que procedem da sua origem enquanto grupo social. Isso equivale a enunciar que, em paralelo às relações oficialmente previstas, existem outras que escapam à projeção, porque se originam da própria dinâmica de um determinado grupo social escolar. Dessa maneira, se há uma ordenação administrativa análoga para todas as instituições escolares de determinado tipo, pode-se afirmar que cada uma destas é diferente da outra, por exibir características devidas à sua própria sociabilidade.

Volto ao que mencionei acima sobre a dificuldade em reconhecer o Âncora como um ambiente escolar. Quando lá cheguei pela primeira vez, o portão estava aberto e sem nenhum tipo de vigilância. Andei um pouco mais em direção ao que seria o centro da escola e fui abordado por um funcionário, que pareceu ter notado que eu estava perdido e, gentilmente, perguntou se poderia me ajudar. Disse-lhe que tinha um horário marcado para visitação. $\mathrm{O}$ funcionário se dirigiu até um prédio amarelo e, dentro de poucos minutos, voltou com uma jovem de 10 anos de idade. Descobri que aquela seria a minha "guia turística". A garota, que 
apresentava sua escola com muita alegria, transparecia uma sensação de prazer naquela atividade que pude notar raríssimas vezes em estudantes durante minha curta carreira docente de oito anos. A menina apertou minha mão e disse: "oi, Fernando. Tudo bem? Estava te aguardando ansiosamente. Desculpe a demora, mas ainda bem que estou dentro do horário combinado, né. Vamos começar o passeio?”. Concordei apenas com um monossílabo, pois estava realmente impressionado com a capacidade de comunicação e responsabilidade presentes em uma criança tão pequena.

Enquanto caminhávamos, ela apontava para as diversas instalações da escola e falava sem intervalo: “você está gostando?”, “nossa escola é muito bonita, né?”, “às vezes tenho vontade de ficar aqui para sempre", "a hora mais triste do dia é quando minha mãe vem me buscar, porque em casa não tenho muito o que fazer". Depois de conversar com outros estudantes, vi que essa sensação de pertencimento não era exclusiva da minha guia: pelo contrário, a maior parte das crianças tem bastante orgulho em fazer parte da escola. Gostam de anunciar pela vizinhança que estudam no Âncora. Aliás, a escola é bastante admirada pela comunidade. Não é à toa que a lista de espera para a matrícula ultrapassa o número de 900 pessoas. Pelo reconhecimento ${ }^{8}$ conquistado, famílias de todo o país almejam uma vaga para os seus filhos. No entanto, localização e renda são os principais critérios para matricular-se no projeto. Tais requisitos foram estipulados pelo serviço social, por se tratar de uma ONG. Mas, segundo a funcionária responsável pela captação de recursos, "há um real interesse da instituição em receber todo mundo". Ela declara ainda que "existe um esforço coletivo que poderá trazer para o Âncora novos perfis socioeconômicos". Assim, estarão cumprindo com o que a funcionária diz ser o "verdadeiro papel social da escola", que não se realiza de maneira segregada.

Seguimos com nosso passeio pela escola. Um lugar amplo e agradável. À primeira vista, existe uma espécie de "bagunça organizada" aos olhos do estrangeiro. Olho para um lado e vejo alguns adolescentes cantando um funk cuja letra exaltava o movimento LGBT. Olho para o outro lado e vejo algumas crianças andando de skate, enquanto outros liam tranquilamente sentados em círculo no gramado. Entrevi o que parecia ser um professor conversando com

8 Entre 2012 e 2018, a Escola Projeto Âncora foi citada mais de 6 mil vezes em mídias sociais. Os estudantes, crianças e adolescentes, deram mais de 30 palestras em instituições espalhadas pelo Brasil e Portugal. Realizou convênios com 60 instituições escolares que fizeram imersão na entidade, e promoveu um curso on-line para divulgar as práticas educativas da escola que atingiu a marca de 2.000 inscrições (informação pessoal). 
algumas crianças, vestindo um traje descontraído, chinelo e bermuda jeans. Testemunhei também uma cena de um rapaz, que aparentava ter uns 14 anos, sendo advertido, após jogar um papel no chão, pela menina que me acompanhava. Ela disse a seguinte frase: "se continuar fazendo isso vou levar o caso para a próxima assembleia. Estamos de acordo?”. O rapaz se lamentou e disse que aquela ação não mais se repetiria. Enquanto o garoto se distanciava ela arrematou dizendo: "já é a segunda vez nesta semana que vejo ele jogando lixo no chão".

Naquela altura do passeio nada mais me impressionava, pois tudo consistia em novidade. Continuei admirando as diversas instalações da instituição e não parei para refletir, naquele momento, no significado do "confronto" geracional pacífico que havia presenciado. Mas agora vejo que aquele comportamento só pode se fazer presente em um ambiente regido por acordos consensuais. Como seria possível exigir que estudantes cobrem regras de conduta, nas quais não tiveram nenhuma participação? Algo que é comum presenciar nas escolas convencionais são alunos respeitando ou se revoltando contra as ordens formuladas de cima para baixo. $\mathrm{O}$ que resulta em uma agressividade exagerada. Nesse sentido, concordo com as palavras de Neill (1970) ao ser questionado sobre o comportamento das crianças na escola de Summerhill:

\begin{abstract}
As crianças de Summerhill mostram tendência agressiva, coisa habitual nas crianças comuns? Bem, toda criança deve ter alguma agressividade, para forçar seu caminho através da vida. A agressividade exagerada, que vemos nas crianças não-libertas, é um protesto exagerado contra a animosidade que se demonstra em relação a elas. Em Summerhill, onde criança alguma se sente detestada pelos adultos, a agressividade não é necessária. (p. 18)
\end{abstract}

Fica fácil reconhecer que um estudante dará muito mais valor a uma sala limpa quando ele também for responsável pela manutenção da limpeza. Assim como dará mais valor à alimentação quando participar do processo de preparação. Na Escola Projeto Âncora, não é a direção que cuida dos computadores ou dos livros da biblioteca. Não é a direção que organiza o jardim da escola. Professores, alunos, funcionários e pais compartilham responsabilidades e tarefas. Conforme afirmou uma das educadoras do projeto: "qualquer atividade que acontece na escola é pensada de forma pedagógica, seja na limpeza, alimentação ou na secretaria. Pensamos e trabalhamos juntos a todo momento". Isso resulta em uma democratização do espaço escolar. O que não significa uma nivelação dos distintos lugares de seus agentes, ocultando a diversidade que lhe é característica; longe disso, é por meio da diferença dos seus 
agentes, partilhada e assentida entre as partes, que é possível garantir um espaço e uma vida mais coletiva.

Outra questão que vale ressaltar é que, como já apontei, toda escola constitui um ambiente social peculiar e, por isso, é representada por inúmeras formas de tensão e/ou acomodação entre, de um lado, administradores, ou reformadores como prefere Torres (2000), e docentes - representando os padrões consolidados da sociedade - e, de outro lado, os jovens, que deverão equacionar, na sua conduta, as exigências daquela com as da sua própria sociabilidade. Conhecer adequadamente essa realidade só se faz possível mediante uma minuciosa análise sociológica, que pode tornar um pouco mais transparente a barreira administrativa, dando acesso ao modus operandi das relações estabelecidas, que nem sempre são reconhecidas pelo observador desprevenido. Acredito que adotar este ponto de vista pode romper com certas práticas costumeiras implicadas nesse âmbito das relações de poder, permitindo uma ação educativa mais compreensiva. Posto isso, creio que o educador será capaz de analisar de maneira mais adequada a realidade de cada escola, que não lhe ocorrerá mais como um "espaço de ensino" a ser delimitado nas normas racionais da legislação escolar, mas sim como algo autônomo, extremamente vivo no que tem de peculiar e por assim dizer único.

Por falar em ambiente vivo e pulsante, retorno à descrição do nosso passeio pelo Âncora. Em direção ao centro da escola, está a edificação que mais chama a atenção do visitante, seja pelo valor simbólico, seja pelas cores vibrantes ou pelo seu uso: é uma extensa tenda de circo circundada por uma horta. Ao lado do circo fica a quadra poliesportiva. Entre o circo e a quadra, estão as duas construções que têm acesso por uma via pavimentada por concreto drenante retangular: o ateliê de artes e o refeitório. Num nível superior ao refeitório temos as salas de aprendizagem, laboratórios e biblioteca. Seguindo na direção do bloco da administração, encontramos uma pista de skate e algumas habitações para hospedar visitantes que desejam participar da "vivência transformadora". Chegando aos fundos dessas habitações fica a construção apelidada de "casinha”, uma edificação com vários espaços internos, destinada às crianças menores que, basicamente, correspondem à faixa etária do que é conhecido como

9 É um programa pago que tem duração de sete dias. Nesse período, os participantes têm a possibilidade de se envolver ativamente com as atividades do projeto, acompanhando a dinâmica dos trabalhos na escola e participando de diversas reuniões com educadores para reflexão e esclarecimento de dúvidas. No pagamento da vivência estão inclusos atendimento, alimentação e alojamento. 
educação infantil. Por ali estão reunidos alguns brinquedos ao ar livre e uma pequena área arborizada.

Quase ao fim da minha visita pela escola, não conseguia identificar a presença de certos espaços que são comuns em outras escolas. Questionei a minha atenciosa acompanhante sobre a localização da sala dos professores, da sala dos coordenadores e da mais famosa, conhecida como sala da diretoria. Ela me respondeu de forma simples e objetiva: "fique tranquilo, você não conseguiu enxergar essas salas porque aqui, na nossa escola, elas não existem". Antes que eu pudesse colocar outra indagação, a jovem arrematou: "aqui qualquer sala pode ser utilizada por todos". Fiquei surpreso, pois em escolas comuns é fácil reconhecer essas instalações, porque geralmente são muito diferentes e se destacam em relação às demais. Já no Âncora, o espaço é circular e não há nenhum tipo de distinção entre o lugar dos estudantes e o lugar dos professores. Além do mais, não fica claro qual é o ambiente que possui "mais valor": a biblioteca não se destaca como uma edificação especial, o ateliê de artes não é diferente da sala de música ou dos laboratórios.

Encontro nessa escola a expressão da igualdade manifestada em sua arquitetura, o que é parte da sua ideologia, um círculo sem níveis hierárquicos. Creio que é assim que se constrói um lugar que manifesta uma profunda conexão entre as crenças e a infraestrutura. Essa conexão foi atestada pela fundadora e também arquiteta do projeto. Declarou-me que sua intenção, ao pensar o projeto arquitetônico, foi balizada pela ideia de formação de cidadãos, onde a "missão era ser um espaço, um lugar, onde você aprende na prática e depois multiplica a cidadania". Por esse motivo, o projeto foi concebido para ser uma pequena cidade. No centro geográfico dessa minicidade está o circo, que é uma espécie de praça. Assim como numa cidade interiorana, onde a praça é o local de encontro das pessoas. “O circo é a nossa ágora”, disse a fundadora. É dentro dele que acontece as assembleias, as reuniões, as apresentações, os debates e as festas. Segundo ela, "tudo de importante e que envolve a comunidade aconteceu e acontecerá dentro do circo". A fundadora acredita que o picadeiro "é um local privilegiado, pois as pessoas conseguem se sentar e olhar de frente umas para as outras". Pois não existe "o melhor lugar" e, assim, "todas podem se manifestar a partir de um mesmo ponto".

O propósito arquitetônico pensado a partir da ideia de uma cidade também é aludido no Planejamento Estratégico (1998) da escola. O documento informa que a Escola Projeto Âncora foi pensada, desde o início, para além de uma "entidade social", com o objetivo de ser 
a "Cidade Âncora". Tal cidade possibilitaria uma experiência educativa de desenvolvimento da cidadania e inspiraria "um sentido comunitário mais profundo". Nas palavras da fundadora, esse planejamento foi gerado a partir da seguinte indagação: "como seria uma cidade democrática?". A resposta a questão possibilitou iniciar a construção do projeto:

Toda cidade tem uma prefeitura, então a secretaria representaria isso. A questão
organizacional aconteceria dentro dela. Assim, um dos objetivos era proporcionar à
criança experiências com a matemática junto aos funcionários do setor financeiro e
aprender outras questões burocráticas com as secretárias. Isso é aprender fazendo.
Numa cidade também tem a preocupação e o cuidado com a saúde. Por isso
construímos um ambulatório com médicos, psicólogos, dentistas e nutricionistas. Na
cidade também existem lugares para as atividades físicas, que engloba também o tema
da saúde. Assim criamos a quadra poliesportiva. Atualmente entendemos a questão
da saúde de uma forma mais ampla. Nós nos preocupamos com a prevenção. Criamos
também salas de aprendizagem. Mas não são locais exclusivos para a aprendizagem,
pois pensamos todos os lugares como espaços de aprendizagem. Cada espaço, interno
ou externo, dentro ou fora da instituição, serve como local de aquisição de
conhecimento. Aproveitando uma área verde, em torno de 12 mil m ${ }^{2}$, fizemos uma
extensa horta para representar uma área rural. Enfim, montamos uma infraestrutura
com o esgoto, eletricidade e água por baixo da terra. Planejamos tudo como uma
cidade para que todas as crianças realizem experiências diversas. Afinal, todas vivem
em uma cidade. (informação pessoal)

A arquiteta, pelo fato de ter sua formação pautada pela teologia da libertação, também disse ter buscado inspiração em uma encíclica papal que descrevia aquilo que seria uma cidade justa. Pude observar que, de modo geral, as edificações da Escola Projeto Âncora são simples e possuem um baixo custo de execução e manutenção. Mas os espaços são amplos e conseguem atender suas respectivas demandas. $\mathrm{O}$ único fator preocupante é a inexistência de elementos que garantam a acessibilidade de estudantes com mobilidade reduzida. Entretanto, esse tema já está sendo discutido pela comunidade escolar a fim de obter as adequações necessárias. Afinal de contas, como me relatou um educador, "a entidade não almeja uma formação para a cidadania, mas na cidadania".

Essa explanação me fez recordar Paulo Freire, que, em seu livro Educação e mudança, criticou uma certa "tradição pedagógica" que teima em restringir o aspecto pedagógico ao confinamento de uma sala de aula (2011). O autor explorou a possibilidade de essa característica ser uma investida de controle, não só ideológico mas também espacial. Nesse sentido, "derrubar os muros da escola" para que ela se comunique com o restante da cidade aparenta ser uma conduta antipedagógica. Daí a importância da fala do educador do Âncora que venho de citar. Enquanto as discussões importantes permanecerem restritas e isoladas dos problemas reais, ou seja, distantes das decisões políticas, não será possível alcançar o modelo 
ideal de cidadania, que tantas instituições ambicionam. Assim, a premissa básica de uma escola que visa esse ideal é a de que uma criança, convivendo em um espaço que respeita, escuta e protege os seus direitos e opiniões, terá no futuro a consciência para proteger os direitos humanos, e condições para criar um modelo de vida estabelecido por uma cultura mais democrática.

Estudantes de escolas que se desenvolvem em um ambiente mais democrático, sem pressa e aos poucos, começam a fazer perguntas sobre o processo. Questionam incessantemente sobre o espaço que os cerca. Diversos educadores relataram que constantemente as crianças perguntam: "por que decidiram construir isso aqui e não ali?". Ou então: “quem foi que tomou tal decisão?". Sabem que não serão punidos e, por isso, interrogam. Eu mesmo presenciei um jovem questionando a pintura da quadra. Outro aluno perguntando e, ao mesmo tempo, pensando em possíveis soluções para aumentar a pista de skate. Uma menina que interpela-se alguém sobre o horário de funcionamento da biblioteca em determinados períodos. São inúmeros os exemplos.

$\mathrm{Na}$ outra ponta, os exemplos também são numerosos. Tive a oportunidade de visitar escolas onde sequer as crianças tinham o direito de reclamar. Expressões do tipo "aluno não tem que querer nada" ou "se você falar mais alguma coisa será suspenso por x dias" eram bastante comuns nesses ambientes. Acredito que a maioria das crianças pequenas não sabe, teoricamente, o que significa uma ditadura. Mas penso que aos poucos elas vão compreendendo que são os adultos os responsáveis pelas regras, pela vigilância e pelas advertências a que são submetidas. Em outras palavras, há uma autoridade manifesta que se encontra nas mãos dos adultos. Ou seja, a pessoa que a pratica se dirige com franqueza àquela que lhe está sujeita, dizendo, por exemplo: “faça isto senão será castigado". Logo, não aprendem sobre a ditadura, mas são criadas dentro de uma.

Falo sobre a autoridade manifesta ou declarada, mas existe outra que é mais sutil, pois esconde o emprego da força. Essa é a autoridade anônima. Ou seja, a pessoa que a executa finje que não há qualquer tipo de coerção, que tudo está sendo realizado com o consentimento de cada qual. Geralmente, resulta em frases como "tenho que certeza de que gostará dessa atividade" ou então "faça isso para receber aquilo". Neill (1970) já alertava sobre a transformação da autoridade manifesta nessa autoridade anônima. Dizia que essa transição forçou o homem moderno a sustentar a ilusão de que tudo é feito perante sua permissão, mesmo 
quando essa lhe é retirada através de um controle imperceptível. Destarte, sua permissão é obtida, mas na sua retaguarda e para além de sua consciência. Tal alerta é válido para a educação dita progressista que, muitas vezes, tem forçado os alunos a engolirem uma pílula com uma cobertura de caramelo. Confundindo, assim, uma educação despida de autoritarismo com uma educação por meio da coerção oculta.

Nossas escolas, por muito que me perturbe a afirmação, ainda são, como outras organizações, abrigos de micropoderes, mais ou menos ocultos, extremamente resistentes aos processos de mudança e de democratização. Acredito que as manifestações de indisciplina são consequências da impotência que advém da perda de credibilidade das instituições. Por exemplo, na determinação de que "não é permitido fazer isso ou aquilo", a maioria dos alunos lerá essa frase como um desafio: "vamos fazer isso só para chatear os professores". Na Escola Projeto Âncora, não identifiquei situações desse tipo. Ao contrário, encontrei uma escola que foge aos moldes da punição. Encontrei uma escola que tem barulho, que tem uma pulsão de vida. Que não se permite ser uma escola silenciosa, pois “onde há muito silêncio”, segundo as palavras de uma gentil professora, "há muita repressão".

No Âncora há de fato a adoção da liberdade como um valor fundamental para o processo de aprendizagem. As crianças não precisam chegar no mesmo horário. Não precisam tirar férias no mesmo mês. Não precisam aprender as mesmas coisas ao mesmo tempo. E, para que a exemplificação fique no âmbito do espaço físico, as crianças podem circular livremente pelas diversas instalações da escola. Mesmo quando existe algum tipo de impedimento, este é precedido por um debate. Como quando, por exemplo, pude presenciar dois grupos de alunos antagônicos que discutiam o uso do circo. De um lado, uns defendiam a utilização do espaço e dos seus instrumentos de maneira autônoma, sem a presença de um educador. Do outro lado, o segundo grupo rebatia argumentando que o espaço circense não estava sendo usufruído com responsabilidade por alguns estudantes e por isso necessitava de controle e supervisão.

Outro exemplo de preocupação coletiva sobre a utilização do espaço foi a questão da alimentação. Um estudante me contou que antes havia um grande desperdício de comida durante as refeições da escola. A descoberta desse fato foi realizada de maneira prática ao resolverem reunir todos os restos de alimentos desperdiçados durante um almoço. Incomodados com o fato, todos se comprometeram em alterar esse cenário. Estudantes e professores também se reuniram para pesquisar os índices de desperdício de alimentos na sociedade. E, com os 
dados em mãos, descobriram que o Brasil figurava entre os principais países em quantidade de alimentos desperdiçados. O mesmo estudante disse que se sentiu empoderado após participar desse processo de renovação do espaço e que passou a controlar o desperdício na sua própria casa.

Esses bons exemplos de organização pedagógica a partir dos interesses das crianças demonstram que a escola não pode mais se reduzir a um mero local de transmissão de conhecimentos. Cabe à escola ser um espaço de valores, de convivência, de ressignificação, de visão crítica do mundo, de criação e protagonismo. Alguns agentes escolares colocam a culpa dessa limitação no que chamam de "burocracia excessiva". De fato, não nego sua existência, mas não penso que a burocracia necessariamente bloqueia ideias. Pelo contrário, às vezes podem se encontrar maneiras criativas que autorizem as "burocracias excessivas" a dar suporte a novas ideias.

José Pacheco declarou-me, em uma das entrevistas, que enxerga a situação acima de uma forma mais pessimista. Para ele, "a escola atual não tem solução, ela tem limites”. Pacheco acredita que as escolas convencionais não podem ser melhoradas. Segundo ele, "é preciso reconfigurar a escola" e, para isso, "é necessário estabelecer, com os órgãos de poder, estratégias de negociação de um termo de autonomia". Isso porque, se "as escolas não forem autônomas, não adianta colocar nos PPPs [Projetos Político-Pedagógicos] que o objetivo é criar alunos autônomos". Pacheco ainda finaliza dizendo que "as escolas da forma como estão organizadas não cumprem nem a LDB [Lei de Diretrizes e Bases]”.

Pode ser uma visão otimista da minha parte, mas vejo que as escolas públicas brasileiras estão despertando para essa organização mais autônoma como propõe Pacheco. O episódio das ocupações dos secundaristas, em 2016, contra a reforma do ensino médio demonstrou esse aspecto. Despertou-se para necessidade de uma gestão que seja dialógica. Uma gestão mais democrática com participação direta dos estudantes e comunidade nos processos decisórios. Claro que os efeitos da pós-ocupação ainda estão em andamento. Serão necessários mecanismos institucionais que garantam espaços mínimos para essa participação acontecer. No entanto, será uma perda de oportunidade se as administrações não pararem para refletir na maneira como o sistema educacional poderá incorporar as mensagens que foram emitidas por esses jovens. Estes jovens se depararam pela primeira vez com a necessidade de organização para o estabelecimento de regras de convivência entre eles. 
Durante as ocupações contra a reforma do ensino médio, os educadores e estudantes do Projeto Âncora também pararam e abriram espaço à comunidade para virem conversar sobre a situação do país. Conforme contou-me um educador, os integrantes da escola procuraram acompanhar e estabelecer contato direto com os estudantes das escolas públicas. Inclusive alguns estudantes do projeto conseguiram captar recursos e foram para Brasília participar de protestos. Houve também estudantes que participaram regularmente das reuniões do Plano Diretor e de sessões na Câmara dos Vereadores do município de Cotia acompanhados por educadores, algo que, segundo esse educador, se estende até hoje. Narrou-me também que a Escola Projeto Âncora busca um fazer que está "intimamente ligado à formação da consciência, com vistas à vivência da democracia, incentivando a responsabilidade social”, para que, assim, os estudantes possam "ser capazes de conscientemente fazer opções políticas e participar como cidadãos construtores da história do país".

Vale ressaltar que as dificuldades de modificar certas práticas nas escolas são de natureza diferente. Nas escolas da rede pública, por exemplo, identifico uma ampla escassez de recursos e interferências de burocratas. Nas escolas da rede privada, noto, em sua maioria, a interferência dos burocratas e as exigências e caprichos de certos pais. Contudo, a maior dificuldade é comum. Ambas carecem de espaços de convivência reflexiva. Faz-se necessário compreender e conhecer melhor as pessoas presentes no cotidiano escolar, saber quais são as suas necessidades e interesses específicos. Considero que o conceito de cidade educadora, aplicado pelo Âncora, acompanha esse pensamento. A ideia é pensar, aprender, viver e resolver questões em comunidade. Cada uma das pessoas que pertence a essa cidade reconhece a sua importância enquanto educadora. Todos os saberes, todos os fazeres e todas as oportunidades que se apresentam em uma comunidade fazem parte da vida de todos. Assim, para sabermos como atuar na nossa comunidade, é fundamental o conhecimento do lugar em que estamos.

Atualmente, existe uma iniciativa originada pelos pais na Escola Projeto Âncora. É uma Associação de Famílias e Amigos do Projeto Âncora (AFAPA), que entendeu, segundo depoimento de uma mãe participante, que a instituição escolar "não deve ser pensada para as famílias, mas sim com as famílias". Essa mesma mãe contou que o primeiro passo foi romper com os ditos "horários de funcionamento da escola" para dar "condições de participação da comunidade no processo de construção da escola" que eles acreditam ser a ideal. Assim, organizam vários grupos de apoio aos trabalhos operacionais, promovem eventos, praticam ações de voluntariado e participam de assembleias, discutindo e encaminhando propostas sobre 
diversos assuntos, seja no plano administrativo, seja no pedagógico. Também auxiliam no processo de familiarização dos jovens ingressantes do Âncora.

Segundo o relato de um educador, o papel prestado por essa iniciativa dos pais é de grande valia, pois há uma grande preocupação em "preparar as condições favoráveis para a integração socioemocional das crianças ao ambiente escolar, escolhendo o seu lugar no espaço de trabalho, falando e ouvindo os colegas sobre as suas experiências em relação à família, gostos, preferências e inclinações". Pude acompanhar a recepção de novos alunos e percebi que, de fato, todas as pessoas envolvidas com a escola tentam criar o melhor clima possível para receber e ambientar os recém-chegados. Como estratégias de adaptação, são realizadas brincadeiras de apresentação pessoal, dinâmicas de grupo, rodas de conversa sobre suas expectativas de vida, entre outras. São feitas perguntas do tipo: o que esperam da escola? O que querem aprender? O que gostam de fazer? Dessa forma são "desenhados" os primeiros passos de cada estudante que chega ao Âncora.

Quando um estudante entra no Âncora, uma das primeiras coisas que ele faz é escolher a qual grupo de responsabilidade ${ }^{10}$ ele gostaria de pertencer. Estas "responsabilidades" cobrem praticamente todas as áreas da vida escolar. Dentro de cada grupo são pensadas estratégias para cuidar de determinado aspecto na escola. Existem inúmeros grupos que cuidam das mais diversas tarefas, como materiais didáticos, alimentação, hortas, biblioteca, laboratórios, tecnologia, esportes, visitas, entre outras. Não necessariamente os estudantes realizam concreta e exclusivamente a tarefa proposta por um grupo, como, por exemplo, limpar a escola inteira: eles podem pensar possibilidades para manter o local limpo e conservado.

Os GRs, como são conhecidos, conferem direitos e deveres e são geridos quase que exclusivamente pelos estudantes. Cada professor orienta um determinado grupo, mas quase não interferem nas discussões. Também é importante esclarecer que os grupos de responsabilidade assumiram diferentes formas ao longo da trajetória do projeto. Atualmente, por exemplo, nem todos os problemas coletivos são resolvidos por um grupo existente. O que existe é um caminho percorrido pelo qual cada educando compreende a importância do trabalho coletivo e se apropria dele. Dessa forma, parte desse caminho pode ter o dever como instrumento

10 Os grupos de responsabilidade foram inspirados pela Escola da Ponte (Portugal) e por uma escola da antiga União Soviética chamada Colônia Gorki. 
pedagógico, como, por exemplo, cuidar do material coletivo ${ }^{11}$ das salas de aprendizagem. Todavia, tal instrumento obrigatório pode se tornar ultrapassado uma vez que um GR assume tal tarefa.

Os grupos de responsabilidade nascem de alguma questão que precisa ser resolvida e, em assembleia, são escolhidos os membros que participarão das comissões que se tornarão GRs. Um dos educadores, responsável pelo grupo de responsabilidade dos esportes, me explicou a forma como concebem esse dispositivo de aprendizagem. Elucidou, primeiramente, sobre a participação das crianças. Disse que fazer parte de um grupo não envolve obrigatoriedade. Mas, aos que desejam integrar um determinado grupo, é facultado o direito de escolha pela área com a qual possui maior afinidade. Antes de optar por um grupo, também é possível conhecer vários. Assim, quando algum dos grupos começa a fazer sentido para a criança, ela poderá aderir a ele, algo que acontece com bastante frequência, segundo o educador. Apesar da escolha ser facultativa, o professor esclarece que "há um forte estímulo para que ocorra a participação das crianças a todo momento", pois todos os educadores estão convictos de que "o envolvimento com o coletivo é parte necessária da caminhada de qualquer criança que faça parte da escola".

Seguindo esse posicionamento dos educadores, a coordenadora pedagógica da escola questiona: "Como uma criança vai participar ativamente das decisões e transformações do seu bairro se ela não faz isso na sua própria escola?”. Segundo ela, as crianças do Âncora, ao participarem dos grupos de responsabilidade, "começam a olhar para o mundo de uma maneira diferente: não com o olhar da queixa do 'não fizeram para ela', mas com olhar do 'qual foi meu papel pela melhoria?'”. Quando você tem uma estrutura hierárquica muito verticalizada, nas palavras da coordenadora, "parece que você exime também aquela pessoa de ter responsabilidade porque ela está sendo mandada". Já, "quando você transfere para as crianças essa necessidade da autodisciplina, elas se tornam mais responsáveis". Para ela, "a problematização é uma forma fantástica de aprender na prática". Por esse motivo, "o desenvolvimento de tarefas executadas pela inteligência coletiva atinge amplas soluções para problemas comuns do cotidiano".

11 Todo material utilizado na escola é compartilhado. Ninguém traz sua borracha, seu lápis. Para se ter uma ideia, existe um acordo entre as crianças para organizar e contabilizar os materiais. É comum ver o anúncio em placas nas salas de aprendizagem: "35 lápis, 23 borrachas, 9 apontadores, 22 canetinhas e 5 tesouras." 
Um dos GRs mais “disputados” pelas crianças é o do Esporte. Nele desenvolvem tarefas como a compra, distribuição e manutenção dos materiais esportivos. Mas também se organizam campeonatos externos e internos das mais variadas modalidades esportivas e se promovem avaliações físicas para todos da comunidade escolar. Pude participar de alguns encontros promovidos pelo grupo e presenciar discussões como mudança e conservação do depósito de materiais, promoção de torneios, aquisição de uniformes, reforma da quadra poliesportiva. Presenciei também outras pautas importantes, como a questão da inclusão de meninas nos times de futebol e de meninos que não gostam de praticar esportes que eles consideram femininos.

Os GRs não somente executam tarefas, mas também criam novas tarefas. Foi assim que o GR da Biblioteca se reuniu para realizar um mutirão de catalogação virtual dos livros. Aconteceu em um sábado, com a presença de 50 voluntários que, sob as orientações dos educandos e educadores, realizaram a organização de mais de 500 livros. A iniciativa partiu da ideia das crianças do GR para melhorar o processo de pesquisa da escola. A catalogação permite que os estudantes, a partir de qualquer computador da escola, acessem o sistema de busca e encontrem os livros necessários para suas investigações a partir de palavras-chave. Também permite uma melhor organização dos livros nas estantes e facilita os empréstimos. Segundo um estudante que fez parte da ação, os livros passaram a circular cada vez mais, não só dentro como fora da escola. No entanto, segundo ele, o verdadeiro sonho do grupo ainda não foi atingido: abrir a biblioteca, inclusive aos finais de semana, para toda a comunidade.

O GR da Horta e o GR da Alimentação também se uniram para promover mudanças estruturais no que consideraram como a "saúde da instituição". Desenvolveram cardápios de forma participativa com todos que ali se alimentam três vezes por dia. Conscientizaram as pessoas da escola, através de campanhas e ações informativas, sobre a questão social e ambiental que envolve a produção dos alimentos na nossa sociedade atual. Estimularam o cultivo de temperos, leguminosas e hortaliças no terreno da própria escola. Debateram também sobre vegetarianismo e veganismo, o que acabou resultando na adoção da "segunda sem carne". Os resultados dessas ações foram significativos: o grupo fez um levantamento e percebeu que houve uma diminuição no uso do açúcar e no consumo de carne, além de um aumento no consumo das hortaliças e de sucos naturais. Um grupo de estudos sobre ervas medicinais também foi fundado e surgiram várias parcerias com pequenos produtores rurais ligados à agricultura orgânica. 
Essa ação pautada por escolhas alimentares mais saudáveis se fez a partir do aprendizado das propriedades nutricionais dos alimentos e suas respectivas funções para o organismo. Os estudantes conseguiram construir uma nova cultura alimentar na escola para além do campo da saúde. Ao incentivarem certas alterações de produção e consumo, houve um aprendizado de aspecto socioambiental e, sobretudo, político. Creio que não seja possível falar sobre desconstrução de certas práticas costumeiras sem abordar o problema da alimentação diária das diversas instituições. Há um descaso com o gerenciamento da merenda escolar, principalmente quando o assunto é a educação pública (vide o caso da máfia da merenda ${ }^{12}$ ).

Outro grupo de responsabilidade que acompanhei mais de perto, participando de algumas de suas reuniões semanais, foi o da Tecnologia. Esse grupo cuida basicamente da distribuição, aquisição e manutenção dos aparelhos eletrônicos da instituição (notebooks, tablets, equipamentos de som...). Além dessa parte operacional, o grupo também define as pautas sobre a utilização da tecnologia no ambiente escolar. Normalmente as reuniões começam pelos recados da semana, seguem para as reclamações e depois se completam com a pauta do dia.

A discussão mais empolgante que presenciei foi sobre o uso dos celulares. A questão inicial do debate girava em torno da liberação ou restrição dos aparelhos. Nas palavras proferidas pelos próprios estudantes: “pode mexer ou não nos smartphones?”. Vale lembrar que essa preocupação não surgiu pelo motivo que comumente aparece em outras escolas, de que mexer no celular "atrapalha" o andamento das aulas. Ou melhor que "atrapalha" a exposição do professor. Até porque não existem aulas no Âncora. Surgiu simplesmente a partir da constatação de alguns estudantes de que muitos de seus colegas não possuíam recursos financeiros para adquirir um aparelho.

Após expressarem suas concordâncias e discordâncias, os estudantes levaram várias demandas para serem resolvidas em assembleia. Foram estabelecidos os seguintes combinados: 1) devemos utilizar o celular em horários determinados, pois a rede de internet não suporta um tráfego intenso; 2) mexer no celular somente após a realização do planejamento diário; 3) o

12 Esquema de desvios e superfaturamento de compras de alimentos para escolas públicas em São Paulo, que resultou na acusação formal de nove pessoas. As investigações começaram em 2016, com a operação denominada "Alba Branca", comandada pela Polícia Civil e pelo Ministério Público Estadual. 
celular poderá ser utilizado para fins de pesquisa; 4) os pais das crianças menores de 13 anos devem assinar uma autorização caso o filho queira usar o Facebook; 5) não queremos proibir, queremos que todos utilizem o celular de maneira positiva, por isso não podemos acessar qualquer tipo de informação que influencie a fazer coisas proibidas para nossa idade; 6) não devemos utilizar o celular durante as refeições; 7) não devemos mexer sem autorização no aparelho de outros colegas; 8) o GR do celular ficará responsável por mediar os possíveis conflitos envolvendo os celulares, podendo, em alguns casos, definir quem possui ou não o direito de usar o celular.

Possivelmente, esses combinados já devem ter sido alterados depois disso, pois, conforme me informou um educador, a discussão sobre o uso do celular na escola é um assunto frequente nas assembleias. Mesmo após o estabelecimento dos combinados apresentados acima, notei reclamações espontâneas de um grupo de meninas, durante o almoço. As queixas envolviam principalmente o combinado de número 8. Uma das meninas se queixava: "acho que esse negócio de supervisão ficar na mão do GR não vai dar muito certo". Outra garota também questionava: "vocês vão ver, eles vão favorecer só quem é amiguinho deles [integrantes do GR de tecnologia]". A terceira garota do grupo arrematou com uma proposta: "vamos levar esse assunto para a próxima assembleia?". Isso é um reflexo da convivência em um ambiente mais democrático. As crianças vão aprendendo desde cedo que conviver com as diferenças de um grupo não significa apenas usufruir os direitos fundamentais, mas também é necessário que todos assumam os acordos e deveres estabelecidos na definição dos rumos da vida coletiva.

Ainda sobre o uso da tecnologia, resolvi coletar opiniões de dois educadores para entender melhor como enxergam e lidam com esse espaço virtual dentro do espaço escolar.

Com ou sem novas tecnologias, a escola precisa ser reinventada. Mas, do modo como as novas tecnologias estão sendo introduzidas nas escolas, temo que se transformem em panaceias, que sirvam para congelar aulas em computadores, aulas que os alunos, acostumados ao imediatismo e à velocidade dessas tecnologias, acriticamente consumam, sem resquícios de cooperação com o aluno vizinho, dependentes de vínculos afetivos precários, estabelecidos com identidades virtuais. A internet é generosa na oferta de informação sob a forma de vídeos, ou de outros recursos. Basta clicar para repetir, até que a matéria seja compreendida. Tudo aquilo que um professor pode "ensinar" numa aula está plasmado, de modo mais atraente, na tela de um computador. (informação pessoal)

É bem verdade que a atribuição de um laptop por aluno virou moda e produz "monstrinhos de tela", que não veem quem está ao seu lado. Que o recurso aos games transformou escolas em "cassinos"... Mas também é verdade que a utilização das novas tecnologias de informação e comunicação são incontornáveis e essenciais para 
o exercício de novas práticas. Aos professores cabe dar resposta ao dilema: irão replicar aulas congeladas no Youtube e em tablets, ou irão usar o digital ao serviço da humanização da escola? (informação pessoal)

Observei que há uma proposta no Projeto Âncora que caminha para além do ensino "on demand", que está sendo amplamente propagado, principalmente nas escolas particulares. Além disso, como pode se notar nos depoimentos, há um distanciamento da ideologia de que os maiores problemas do mundo moderno podem ser solucionados com muita facilidade somente através da tecnologia. No Âncora a tecnologia é apenas mais um recurso. Assim como eles têm a possibilidade dos livros, das rodas de conversa, dos projetos de pesquisa, têm também a ferramenta virtual. Ainda que a internet ocupe cada vez mais espaço em nossas vidas, ela só é acionada no Âncora quando faz sentido. Caso contrário busca-se outro dispositivo. Um exemplo concreto disso: a instituição utiliza plataformas virtuais como o Duolingo e a Khan Academy. Seu uso não esgota, de modo algum, os demais recursos, inclusive porque uma das metas da escola é derrubar o que chamam de "muros" entre as diversas áreas do conhecimento. Tais serviços são vistos como parte do exercício do estudo coletivo, da organização e do compartilhamento.

A escola tem aproximadamente 70 notebooks e 30 tablets disponíveis para uso. Como todo material escolar é de uso coletivo, aquele estudante que necessita só precisa efetuar uma reserva, utilizar o aparelho e devolvê-lo carregado. Dessa forma, não há necessidade de obter mais computadores. É um uso sustentável da tecnologia. E, como política e tecnologia não andam separadas, os educadores e estudantes também refletiram sobre outra prática sustentável, desta vez financeira. Implantaram software livre e se libertaram do controle (e do alto valor) promovido pelo software proprietário. Passaram a disponibilizar, aos poucos, computadores com Linux, além de promoverem a troca por sistemas operacionais livres nos computadores pessoais dos funcionários.

O atrativo do espaço virtual da Escola Projeto Âncora é a maneira pela qual os educadores o concebem: como uma plataforma de aprendizagem e não como uma plataforma de ensino, pois há um modo de se operar a partir de descobertas conjuntas e troca de informações que desfazem o caráter hierarquizado que costumeiramente algumas escolas têm dificuldade de romper. Percebo que o projeto ainda está caminhando para que a utilização da tecnologia atinja toda a sua potencialidade. Um exemplo disso é o processo de desenvolvimento de um ambiente virtual próprio junto a uma empresa parceira, do interior de São Paulo, chamada 
Caiena. Essa plataforma permite que haja uma troca de informações com educandos e famílias, que se organizem dados cadastrais e que se auxilie na aprendizagem das crianças. A ideia é que seja algo construído para facilitar a educação, no lugar da educação submissa à tecnologia.

Antes de finalizar esta reflexão sobre a configuração e utilização do espaço físico da escola, quero fazer algumas considerações acerca daquilo que o mantém: o aspecto financeiro. Conversando com alguns responsáveis pela captação de recursos, soube que a questão financeira é um problema difícil de ser resolvido e que, em certos momentos, é um fator impeditivo. Nos primórdios do Âncora, ainda restrito a uma entidade assistencial, existia um Serviço de Convivência e Fortalecimento de Vínculos, ofertado no contraturno escolar. Durou 16 anos e, nesse período, foi fortalecido financeiramente sob a direção do fundador, que conseguiu fidelizar parceiros que se transformaram em importantes doadores. Quando o Âncora se converteu em uma escola, os custos aumentaram e algumas parcerias se dissolveram. A partir daí, a busca por novas formas de resolver as pendências financeiras aumentou. Conforme narrou um educador, naquele momento muitas famílias ficaram surpresas ao saber das dificuldades enfrentadas pela escola e assim que "entenderam a verdadeira situação passaram a colaborar, seja como voluntários ou até mesmo apresentando novas empresas".

Nesse ínterim, como estratégia de captação de fundos, criou-se na escola o que passaram a chamar de "cantinho do desapego". Um espaço de economia solidária que assegura um local físico para doações e trocas. Tal espaço permite que os membros da comunidade escolar possam entregar objetos que não mais utilizam ou retirar aqueles que lhes interessam. Todas as doações precisam estar em perfeitas condições e a única condição para retirar um pertence é que deve se deixar outro no lugar. É uma solução simples, porém engajada, e está funcionando perfeitamente bem para solucionar algumas das necessidades do projeto e da comunidade de forma colaborativa.

Outra forma importante que contribui para a arrecadação de fundos para instituição é o movimento "Ôkupa Âncora". Este também teve origem na comunidade, no ano de 2015, com a intenção de ocupar os equipamentos da escola fora do período letivo de atendimento às crianças. Foi inspirado por movimentos de participação social com intervenções e ações locais como, por exemplo, o Occupy Wall Street. Há um encontro semanal com oficinas pagas de música, yoga, capoeira, contação de histórias, atividades circenses, teatro e fantoches. Assim, o movimento, além de estimular a arte e a convivência familiar, também fomenta a economia 
criativa. É algo muito diferente de se observar: educadores, crianças e famílias embaixo das árvores realizando juntos uma avaliação semestral enquanto outros arrecadam fundos no bazar, com artesanatos da comunidade ou com a venda de refeições na praça de alimentação. Um final de semana por mês também acontecem os "Domingos sem TV", para fortalecer ainda mais a convivência familiar.

Mesmo com toda essa movimentação que existe na escola, estão longe se acomodar pela busca de recursos. Segundo a fundadora da escola: "percebemos que há muitas riquezas no Âncora que poderiam ser melhor compartilhadas por todos de maneira justa, democrática e colaborativa". Creio que essa atitude de não acomodação é correta, pois, conforme constatou Ghanem (2012a), as inovações educacionais dependem de um alto nível de voluntarismo, são descontínuas no tempo, possuem baixa visibilidade e, por esses motivos, dificuldades com sustentabilidade financeira. É um "preço" que se paga por contrariar um conjunto de prescrições orientadas por uma lógica coercitiva que faz com que as práticas educativas sejam homogêneas. O caminho pode ser penoso, mas é preciso que os "muros das escolas" sejam derrubados e que a vigilância seja desativada, para cederem lugar a espaços de fraterna vizinhança, onde as novas gerações aprendam no contexto das suas comunidades. 


\subsection{Relação entre os diferentes agentes do universo escolar}

Nesta parte do trabalho, exponho as relações entre os diferentes agentes escolares em dois planos: interinstitucional e intrainstitucional. $\mathrm{O}$ primeiro diz respeito às interações entre escola, família e comunidade em geral. O segundo plano engloba as relações interpessoais entre os mais presentes no cotidiano escolar: professores, funcionários e estudantes. Deixo claro que essa divisão é apenas uma opção particular para interpretar a realidade apresentada. Apenas um recorte metodológico. Digo isso porque, na Escola Projeto Âncora, todos são vistos como educadores. Lá não há espaço para se manter na passividade. O responsável pelo jardim é um educador jardineiro. Pela cozinha, um educador cozinheiro. Pelos reparos e consertos, um educador da manutenção, e assim por diante. Isso não isenta os profissionais de suas responsabilidades específicas, porém não ficam restritos exclusivamente a estas. Se você perguntar a qualquer pessoa sobre o assunto, é provável que lhe respondam com a seguinte frase: "aqui todos os educadores são educadores de todos".

O quadro de funcionários é composto de 30 pessoas. Há também voluntários, pesquisadores e estagiários que auxiliam no projeto, mas este número de pessoas varia de acordo com o semestre. Todos que trabalham no Âncora são educadores responsáveis pela criança, mas alguns deles são educadores-tutores, apenas por cuidarem mais atentamente do processo pedagógico. Qualquer um pode ser um educador-tutor, desde que obtenha a formação necessária para ser professor. Duas mulheres que trabalhavam na cozinha, por exemplo, hoje são educadoras-tutoras do projeto. Esse fato não é uma exceção. Já ocorreu inúmeras vezes a transição de profissionais dentro das áreas de trabalho do projeto. São comuns casos de pessoas do setor pedagógico que foram para a área administrativa e vice-versa. A coordenadora me informou que isso só é possível porque "na escola ninguém está preso em uma função" e, por isso, "ninguém trabalha sozinho, existe um sólido trabalho de equipe que possibilita uma ótima interação entre as diferentes partes". Observei a própria coordenadora, muitas vezes, exercendo o papel de tutora, mediando projetos de aprendizagem, organizando grupos de responsabilidade e até mesmo removendo lixos dos lugares de passagem. Tal depoimento se assemelha ao de Pacheco quando diz que "ser professor não pode ser um ato solitário, mas solidário". De fato, concordo que na solidão ninguém é autônomo. Só somos autônomos em equipe.

Atualmente, a carga horária de trabalho dos funcionários da escola é de 44 horas semanais, mas, conforme relatou um professor, esse período pode diminuir ou aumentar, em 
alguns momentos, devido às diferentes demandas que podem surgir, como cursos e reuniões. Segundo o mesmo professor, há uma "busca cada vez maior por uma autonomia em tudo que envolve as características do trabalho docente". Realmente, em uma escola que exalta tanto o valor da autonomia não fariam sentido mecanismos de controle, onde houvesse um diretor para fazer obedecer horários padrão, livros de ponto para assinar ou faltas para justificar. Mesmo estando os educadores de posse dessa liberdade, testemunhei exemplos de elevado profissionalismo. No período em que lá estava, não me lembro de nenhum funcionário que tenha se omitido de suas obrigações. Creio que isso seja o reflexo da possibilidade de uma contratação sem intermediários. Ou seja, só vai para o Âncora quem se compromete a cumprir o seu projeto.

Em contraponto, como exigir que o mesmo aconteça em outras escolas que ainda não conseguiram escapar desse controle? Analogamente a outros conceitos em destaque no campo educacional, a autonomia dessas instituições escolares ainda não saiu das páginas do estatuto ou das páginas de trabalho acadêmicos. Enquanto existirem livros de ponto ou horários preestabelecidos por autoridades externas à escola, não haverá autonomia. Esta é incompatível com instrumentos de poder verticalizado e controle homogêneo do tempo. Para invocar apenas o bom senso de um argumento cronobiológico, cada ser humano é um ser diferente e único, dotado de um ritmo específico. Assim, é inadmissível a legitimação, por meio de uma cultura autoritária, do estabelecimento de horários de padrão único na maioria das escolas. Seja para os funcionários, seja para as crianças.

Rompendo com esse padrão que, ao mesmo tempo, é um poderoso agente do conformismo, a rotina do educador do Âncora é intensa: pode estar junto a um grupo de responsabilidade, tirando dúvidas na área em que é especialista, realizando tutoria mais restrita aos roteiros de aprendizagem (este item será discutido com maior profundidade no próximo capítulo), conversando com outros educadores, promovendo oficinas ou fazendo qualquer outra coisa, desde que não seja dar aulas expositivas. Como não há uma submissão cega a certos modelos de conduta, o educador tem bastante espaço para pensar e agir de forma criativa. Não é incomum ver uma nova ideia surgir, dentro ou fora do campo pedagógico. Claro que em meio a esses afazeres, percebi um enorme cansaço entre os educadores. Mas, se por um lado a exaustão se fazia presente, por outro lado o contentamento e a sensação de dever cumprido também eram frequentes. Vi professores cansados, mas não estressados nem desanimados com a profissão, o que é bastante comum em outros lugares. 
Infelizmente, na maior parte das escolas onde lecionei ou convivi como pesquisador, a sala dos professores era um verdadeiro espaço de lamentações, brigas e ódios declarados. Não quero dizer, de forma alguma, que essa seja a regra das escolas brasileiras. Estou apenas compartilhando experiências que podem ser comuns para outros educadores no nosso país. Por esse motivo, fiquei impressionado com as experiências que presenciei no Âncora. De longe, o corpo docente mais unido e sincero que já observei. Como seria de esperar, os conflitos existem, mas há uma maturidade nas suas resoluções. Os desrespeitos que testemunhei em outros lugares são inexistentes ali. Conforme notou Neill (1970), sob liberdade os educadores apresentam a mesma boa vontade e felicidade que alcançam os estudantes.

\footnotetext{
Às vezes, um membro novo do nosso corpo docente reage contra a liberdade muito à moda das crianças: não faz a barba, fica demasiado tempo na cama, pela manhã, chega a ferir as leis da escola. Felizmente, a libertação quanto a complexos se faz mais depressa em adultos do que em crianças. (p. 20)
}

Uma outra forma de explicar essa diferença de humor dos professores do Âncora em relação aos demais é a partir do entendimento da forma de trabalho docente. Como os professores do projeto trabalham de maneira coletiva, todos os problemas comuns são compartilhados. Realizam vários encontros informais dentro das exigências originadas no cotidiano escolar. Mas a convivência entre eles também ultrapassa os seus horários de trabalho, constituindo-se em uma melhor forma de aproximação. São bastante solidários e respeitosos uns com os outros. Se revelam comprometidos na transformação de si próprios e na transformação do seu ofício. Lutam para encontrar e melhorar suas atuações políticas dentro e fora do âmbito escolar. Todos eles são categóricos e assumem que "a escola é um projeto político". Segundo narrou um educador: "os que trabalham no Âncora estão dispostos a contribuir para o que representará a derrubada do modelo educacional arcaico herdado do século XIX”.

Admiro os professores que são ousados e mudam suas práticas, saindo de suas zonas de conforto. Acompanho os colegas de profissão que investem tempo no estudo de teorias para melhorar suas performances. Mas também sou solidário aos professores, que pude encontrar em várias escolas, sem motivação para recomeçar ou continuar com suas tarefas. Encontrei muitos docentes desapontados com os percalços da carreira e muitos que não acreditavam mais no papel social da sua profissão. O que mais me chamou a atenção foram as críticas, por parte de alguns profissionais, do que é conhecido como "pedagogia centrada no estudante". Para 
exemplificar, um jovem amigo e professor de uma escola pública do estado de São Paulo me fez o seguinte relato, durante uma conversa sobre novas alternativas no campo da educação escolar:

\begin{abstract}
Olha, Fernando. Com o passar do tempo a gente vai amadurecendo, né. Vai desistindo de lutar por uma escola melhor. Hoje vejo com mais clareza que é melhor deixar tudo como está mesmo. Essas modinhas de pedagogia centrada no aluno não funcionam. Isso só confunde o papel do professor, que é bastante claro: ter conhecimento e passar adiante com os meios que possui. Alguns alunos vão aprender e outros não. Não posso fazer nada. Posso repetir o conteúdo várias vezes. Mas já sei que nem todo mundo vai conseguir acompanhar. (informação pessoal)
\end{abstract}

Sei que pode parecer assustador e, ao mesmo tempo, triste esse depoimento de um professor de apenas 35 anos de idade. No entanto, a tendência é que os educadores reproduzam na escola aquilo que foi apresentado durante a sua formação. Talvez uma mudança nos cursos superiores de formação de professores resultasse em uma alteração no modo de agir na educação básica. Os futuros professores precisam descobrir que não há um modo único de se fazer educação. Não existe um modelo ideal de docência. Muitos estão desesperados, assim como meu amigo acima, porque reduzem a educação a uma ideia de instrução. Como dizer para esses que a sua realidade nem sempre é a verdadeira? Pacheco descobriu um jeito, que não sei se é o mais correto, mas que não deixa de ser relevante:

\footnotetext{
Quando eu quis experimentar a vida de professor universitário, quis saber o que os meus alunos (futuros professores) esperavam do curso. A resposta foi unânime: queremos saber dar aulas e manter a disciplina. Ao que eu retorqui: Então, meus amigos, mudai já de curso e de profissão, que ainda estais a tempo de serdes pessoas felizes. (PACHECO, 2009, p. 37)
}

A Escola Projeto Âncora aborda a questão da formação docente de outra forma. De antemão, sabem que quando um professor deseja trabalhar na instituição ele já está imbuído da vontade de fazer diferente. Ou seja, só estava aguardando um local para colocar em prática aquilo que já almejava. Assim, não existe uma formação extra para ser professor do Projeto Âncora. Basta ser professor. A licenciatura é suficiente. Muitos professores que para lá vão sequer tiveram experiência prévia em outras "escolas inovadoras". Há uma crença institucional de que a melhor formação é aquela que se aprende no convívio com os outros. Desse modo, a formação se dá na prática, na partilha entre os educadores. Por isso muitos são contratados logo após as experiências como voluntários. Isso não significa que a teoria está ausente do processo 
formativo. A própria coordenadora pedagógica adverte: “educação não é só pra quem tem coragem, mas principalmente pra quem tem formação teórica".

A coordenadora segue dizendo que no Âncora "a elaboração do Projeto PolíticoPedagógico é levada a sério". Este serve "como parâmetro para as discussões diárias" e não é apenas "mais um documento burocrático que fica na gaveta como acontece em muitas escolas". É esperado que o educador que chega ao Âncora não seja visto como um mero prático da docência, ou seja, um profissional absorvido por uma lógica instrutiva baseada em práticas de ensino, que determina aos educandos um conjunto de saberes predeterminados. Assim, no lugar de preparar aulas, o educador deverá preparar a si mesmo, tendo como parâmetro o "perfil do educador", definido coletivamente em uma "Carta de Princípios”. Segue o que foi descrito:

\begin{abstract}
Cumpre com pontualidade as suas tarefas, não fazendo os outros esperar; É assíduo e, se obrigado a faltar, procura alertar previamente a equipe para a sua ausência; Contribui, ativa e construtivamente, para a resolução de conflitos e tomada de decisões; Toma iniciativas adequadas às situações; Apresenta propostas, busca consensos e critica construtivamente; Harmoniza os interesses do Projeto Âncora com os seus interesses individuais; Age de forma autônoma tendo sempre em vista os valores do Âncora: responsabilidade, honestidade, solidariedade, afetividade e respeito; Assume as suas falhas, evitando imputar aos outros ou ao coletivo as suas próprias dificuldades; Preocupa-se com a sua formação específica e busca continuamente novos conhecimentos; Dá o exemplo correto na utilização dos recursos disponíveis, primando pela limpeza e pela organização; Concebe o indivíduo em uma perspectiva holística, em seus mais diferentes âmbitos, emocional, intelectual, biológico, natural; Está atento às necessidades dos colegas e presta-lhes ajuda sempre que é preciso; Pede ajuda aos colegas quando tem dúvidas sobre como agir; Permite que os colegas o ajudem quando precisa; Mantém com os colegas uma relação atenciosa, crítica e fraterna; Fundamenta seus pontos de vista sem deixar de admitir perspectivas diferentes da sua; Articula a sua ação com os demais colegas; Apoia ativamente os colegas na resolução de conflitos; Ajuda os educandos a conhecer e a cumprir as regras do Âncora; É firme com os educandos, sem cair no autoritarismo, estabelecendo uma relação afetuosa; Toma atitudes em sintonia com o coletivo; Acompanha de perto e orienta o percurso educativo dos educandos; Mantém uma relação horizontal com os educandos, sem privilégios; Desperta e instiga em cada educando o gosto e a busca pelo conhecimento; Acolhe positivamente a criança e o jovem, independentemente do que eles sejam, pensem ou façam. (PROJETO ÂNCORA, 2012)
\end{abstract}

Espera-se que o educador ocupe, essencialmente, a posição de um mediador no processo de aprendizagem. Por essa razão, ele é chamado a participar da concretização dos documentos pedagógicos, a orientar o percurso educativo de cada educando e a apoiar os seus parceiros de profissão. Assim, a formação inicial e continuada dos professores acontece durante a labuta diária, articulando-se ao projeto, para esse efeito, com outras instituições. Vale ressaltar também que, como os educadores são responsáveis pela tomada de decisões, são avaliados periodicamente em função da Carta de Princípios. É uma avaliação de desempenho. Mas uma 
avaliação formativa e solidária, que não contempla julgamentos ou qualquer tipo de punição. Quando há valores comuns, o resultado é um ótimo trabalho de equipe. Ou melhor, nas palavras de um dos educadores, “quando as inseguranças são resolvidas devido ao suporte emocional de um grupo, ninguém é deixado de lado".

Uma dúvida frequente entre os professores de outras escolas que desejam alterar suas práticas educativas é: por onde começar? Ao questionar os educadores do projeto sobre o que eles achavam dessa questão, obtive algumas respostas esclarecedoras. A primeira sugestão aos que desejam transformar suas práticas foi: "reúnam-se para descobrir novos caminhos". Ou seja, não pode ser um percurso solitário. Segundo os educadores, "escola são pessoas e as relações que elas estabelecem". A segunda sugestão: "tenham paciência". Os estabelecimentos não podem ser mudados rapidamente como em um simples "passe de mágica". A terceira e última sugestão foi: "não sigam receitas pedagógicas". É necessário "pensar através de boas referências", mas também "é necessário eliminar a crença em um modelo pronto e acabado capaz de suprir qualquer tipo de problema educacional”.

Outra sugestão para essa questão foi proposta por Pacheco:

\begin{abstract}
São muitos os entraves para uma reforma educacional. Predomina nas escolas uma cultura que assenta no individualismo, na competição desenfreada, na ausência de trabalho em equipe, na ausência de verdadeiros projetos. Nas decisões de política educativa, prevalece o discurso de economistas, engenheiros, técnicos de informática, jornalistas, gestores, diretores de marketing, ex-ministros, empresários, tudo gente de boa vontade, mas desprovida de conhecimento pedagógico. Talvez devamos apelar ao bom senso dos candidatos e dos titulares do poder público, pedir-lhes que estejam atentos a excelentes práticas que muitos educadores brasileiros vêm produzindo, sem importação de modas pedagógicas, e que são o contraponto da construção social "escola", que a modernidade nos deixou como herança. A velha escola há de parir uma nova educação, mas as dores do parto serão intensas, enquanto a tecnocracia e a burocracia continuarem a invadir domínios onde deveria prevalecer a pedagogia. (informação pessoal)
\end{abstract}

Ainda dentro desse debate, Pacheco aponta para a irresponsabilidade dos gestores: “distantes da realidade vivida e sofrida entre as paredes das salas dos que ainda 'dão aulas', muitos destes que não 'dão aulas' dispõem de tempo livre para complicar a vida das escolas". Agindo de forma esquizofrênica "entre a teoria que dominam e as práticas pedagógicas pobres e reprodutoras". Para Pacheco, por exemplo, "na universidade do século XXI a aula é um verdadeiro escândalo". Segundo ele, "no Âncora e em muitas escolas brasileiras, os professores nelas acolhidos têm condições de reelaboração da sua cultura, oportunidade de se emanciparem da miserável formação que lhes foi inculcada". Desse modo, "não importa em qual instituição 
foram (de)formados, sempre acreditarei nos professores e, por isso, me solidarizo com o processo de transformação das pessoas".

Pacheco segue com um conselho aos professores que desejam mudar, porque, em suas palavras, "os velhos aconselham". Ele pede para que os docentes "não reproduzam, mas se inspirem em bons projetos educacionais como a Ponte e o Âncora, por exemplo". Afirma que, se "as escolas brasileiras fossem organizadas para a aprendizagem, talvez pudéssemos prescindir de pedagogias compensatórias como as da EJA [Ensino de Jovens e Adultos]". Pacheco reconhece e diz que respeita o trabalho realizado pelos educadores da EJA, mas que “EJA, classes de apoio e de recuperação, não são mais do que a confirmação da ineficácia do modelo epistemológico adotado pela maioria das escolas". E, para finalizar as recomendações, Pacheco lança a seguinte questão para reflexão: "pergunto se essa burocracia enquistada no cotidiano das escolas apenas age como um fator de desperdício. Será que as escolas não poderiam passar muito bem sem a tralha administrativa que desresponsabiliza o profissional e infantiliza a pessoa?".

Não pretendo esgotar essa reflexão proposta, mas o que percebi foi que, uma vez rompida aquela forma mais comum de organização escolar, com turmas de alunos divididos por séries em salas separadas, cada uma com um professor - depois que se desfaz o compromisso com essa maneira mais industrial de se organizar uma escola, abre-se todo um leque de possibilidades. O próprio Âncora é uma exploração de possibilidades ao longo do tempo. Hoje existem dispositivos diferentes dos que compunham a sua gênese. Em essência, sempre houve uma busca pelo desenvolvimento da autonomia do aluno, com a corresponsabilização das crianças pela vida da escola. Mas isso se operacionalizou ao longo do tempo de formas diferentes, e ainda continua mudando. O Âncora não mudou de um congelamento para outro. Apenas se desconstruiu e passou a continuamente se reconstruir.

Outro ponto que precisa ser abordado é a relação entre educadores e educandos na Escola Projeto Âncora. Conforme apresentei, o educador é um mediador. É o elo entre estudante e escola, tanto a partir de um aspecto organizacional quanto pessoal. O tutor oferece as condições necessárias para que os estudantes sigam as suas jornadas individuais de aprendizado. Cada grupo de estudantes possui um tutor-orientador específico para acompanhar mais de perto suas atividades. Essa escolha de orientadores não é pré-determinada pela escola. Depende da disponibilidade, e a troca entre eles também é perfeitamente aceita. Assim cada 
educador supervisiona, de maneira mais próxima, cerca de 12 estudantes. Esse número altera com frequência.

Constatei que os estudantes, principalmente os mais velhos, não possuem tanta predileção por algum educador específico. Em algumas falas, naturalmente, é possível notar a preferência de crianças por determinados professores, mas na maior parte do tempo conseguem manter tal coisa ignorada. Possivelmente isso se deve ao fato de os estudantes sentirem que são tratados da mesma maneira por todos os educadores, e tratados com respeito. Os educadores conhecem todos os estudantes e sabem estabelecer limites necessários para cada relação. De acordo com o que expôs um professor: "sei o que [posso] e o que não posso falar para cada criança. Conheço bem suas aspirações, vitórias e derrotas". Segundo um jovem estudante, o contrário também é verdadeiro: "tenho uma ótima relação com meus professores. Já conheci muita gente das suas famílias. Claro que tem vezes que eu acabo passando um pouquinho dos limites, mas depois peço desculpas. Como conheço eles, sei o que posso e o que não posso fazer".

Há um tratamento horizontal entre educadores e educandos, sem privilégios. Não estou dizendo que ambos possuem as mesmas responsabilidades e nem que estão em igualdade de condições no que se refere a experiência e conhecimento de vida. Quero afirmar apenas que não há, no Âncora, uma superestimação e, muito menos, uma subestimação dos estudantes. Aliás, temo, para qualquer instituição escolar, a presença de um valor sentimental exagerado em relação aos alunos. Consinto com o ditado popular que diz ser "tão fácil fazer cisnes dos nossos gansos" - seria como enxergar Van Gogh em uma criança que saiba esparramar tintas sobre a tela. No projeto não acontece isso. Lá, os educadores são firmes com os educandos, sem cair no autoritarismo, e sempre tentando estabelecer uma relação afetuosa.

A crença contrária a essa postura talvez seja o reflexo de uma atribuição indiscriminada da concepção de democracia enquanto a convivência entre pessoas iguais e livres para escolherem e fazerem o que bem quiserem, na hora em que quiserem e sem qualquer tipo de consequência. Acreditar nisso seria a mesma coisa que acreditar na anulação do bom senso. No Âncora, entretanto, precauções são tomadas para a segurança dos alunos. As crianças só podem usar alguns instrumentos mais perigosos com supervisão. Algumas atividades na cozinha são acompanhadas de perto. Nenhum dos alunos pode andar sozinho pelas ruas sem uma prévia autorização. O resultado disso é uma constante luta entre o ponto de vista dos 
adultos e o ponto de vista das crianças. Mas tal embate não descamba jamais para o campo da ofensa pessoal: existe antipatia, mas não hostilização. Neill (1970) tem uma visão mais intransigente sobre a liberdade nas escolas:

\begin{abstract}
Meu ponto de vista é que a criança, de maneira inata, é sensata e realista. Se for entregue si própria, sem sugestão adulta alguma, ela se desenvolverá tanto quanto for capaz de se desenvolver. Logicamente, Summerhill é um lugar onde as pessoas que têm habilidade inata e desejo de se fazerem eruditas serão eruditas, enquanto as que apenas sejam capazes de varrer ruas varrerão ruas. Mas, até agora, não produzimos nenhum varredor de ruas. Não escrevo isso para me dar ares, pois preferia antes ver a escola produzir um varredor de ruas feliz do que um erudito neurótico. (p. 4 , grifo meu)
\end{abstract}

Considero essa visão de Neill muito arriscada, porque, para realizar sua proposta, os educadores precisam renunciar a qualquer tipo de disciplina ou sugestão. Claro que é importante uma escola na qual as crianças tenham liberdade de serem elas próprias, mas os educadores não podem se ausentar das suas incumbências. Seria levar a ideia de liberdade até as últimas consequências - um equívoco do ponto de vista ético e político, pois decorrem ações extremamente individualizantes, para não dizer inconsequentes, em relação à herança do conhecimento público. Quando o adulto só interfere no "mundo das crianças" nos casos extremos, ele está se eximindo da obrigação de apresentar o que há no mundo pré-existente aos imaturos.

Uma das fantasias mais frequentes acerca da Escola Projeto Âncora é a de que a criança é livre para fazer o que quer. Ela tem liberdade para escolher o que estudar, mas não a liberdade de escolher não estudar. O objetivo da escola é fazer com que as crianças aprendam e se desenvolvam, e isso exige trabalho por parte delas. Muitas vezes escutei entre os educadores e até mesmo entre os educandos que a "liberdade não podia ser confundida com a libertinagem". Há uma noção entre as pessoas que fazem parte da escola de que a liberdade precisa caminhar junto com a responsabilidade. Tal concepção teve origem em uma discussão nos primórdios da escola, que procurava por opções para que o coletivo pudesse responsabilizar os atos de cada um. E essa responsabilização não poderia funcionar no formato de punição. Assim, passaram a pensar sobre o conceito de liberdade e chegaram a duas conclusões. A primeira é que a pessoa só pode ser livre dentro de um contexto social. A segunda é que cada ser humano depende de outro para ser livre. Assim, a liberdade de poder brincar, ler e comer depende do mundo inteiro.

Nesse sentido, a questão da disciplina ou da indisciplina na Escola Projeto Âncora pode ser compreendida no âmbito da corresponsabilização. Os estudantes são chamados a 
assumirem a responsabilidade por todos os campos da instituição. Ressalto que os educadores não se omitem da função de orientador. Todos participam ativamente dos processos educativos. Mas as crianças precisam resolver as suas questões disciplinares primeiro entre elas e, se for o caso, buscar ajuda dos adultos. Em casos mais graves que as crianças sentem que não podem resolver sozinhas, elas procuram diretamente seus professores. É uma outra forma de encarar a disciplina quando se é responsável pela mesma.

Sempre que o barulho resultante da interação dos alunos nos seus grupos sobe de volume, um aluno incomodado fica de pé no meio da sala e estende o braço com um dedo levantado. Não pode dizer "xiu" ou mandar calar a boca. Aos poucos ele é percebido pelos demais, e então o volume vai diminuindo. No início, conforme relatou uma jovem estudante, foi complicada a adesão a esse mecanismo, mas com o passar dos anos todos foram se acostumando. Segundo ela, "é uma prática que a gente faz há anos, então já entrou na circulação, integra o DNA do aluno do Âncora". Os próprios pais, nas reuniões da Escola, relatam que em suas próprias casas as crianças propõem esta ideia: de falar um de cada vez, tranquilamente, sem alterar a voz. Repare que a transformação ocorre lentamente e através do consenso entre as pessoas, não é nada mágico ou miraculoso.

Uma das dificuldades que notei e que também está presente em outros trabalhos, como os de Quevedo (2014) e Silva (2018), é a de os estudantes ficarem dispersos pelos espaços escolares, quando deveriam estar realizando aquilo que se propuseram nos seus respectivos planejamentos diários. Para resolver esse problema, algumas estratégias foram desenvolvidas pelos educadores. Uma delas foi o revezamento entre os educadores que circulavam pela escola questionando cada estudante sobre onde deveria estar naquele momento de acordo com seu próprio plano. Nenhuma criança é impedida de caminhar pelos diferentes recintos do Âncora, desde que isso faça parte do seu cronograma diário. Por exemplo: um determinado estudante pode escrever em seu planejamento que dará andamento a sua pesquisa das 9:00 às 10:00 e que, após esse horário, participará de alguma oficina ou andará de skate. Ou seja, toda criança pode estudar ou brincar no horário em que desejar, mas é necessário que assuma seus compromissos acordados previamente.

O hábito de intimidar não é algo comum na Escola Projeto Âncora. Entretanto, como nas escolas convencionais, a razão não é tão difícil de encontrar. Sob uma forte imposição da disciplina por parte dos adultos, qualquer criança se torna hostil. Se não puder expressar essa 
hostilidade contra esses mesmos adultos, sem punições, a criança se voltará para os menores ou mais fracos. Essa prática não está presente no Âncora porque, em primeiro lugar, quando os estudantes (e até os professores) possuem a chance de permanecer em suas áreas de interesse sem serem perturbados ou forçados a abandoná-la, eles adquirem habilidades emocionais e cognitivas substanciais.

Durante muitos anos em que lecionei em escolas comuns pude conhecer bastante a outra fórmula de se alcançar a disciplina. Sempre tive a consciência de que era inadequada. Inadequada por se basear numa percepção adulta do que a criança deve ser, como deve se comportar e o que precisa aprender. Uma prática secular que apenas serviu para legitimar a banalização de um sistema de sanções. Não me lembro de nenhum processo disciplinar que tenha logrado a eliminação da violência nas escolas. Ao contrário, muitos serviram e ainda servem apenas para abafar as tensões. Sob a acepção mais agradável de "normas educacionais disciplinares", a maioria das escolas ainda recorre à "salvação" das advertências, suspensões, repreensões e expulsões como forma de eliminar os conflitos.

Acredito que a indisciplina seja a filha predileta do autoritarismo. Numa escola onde o professor é quem tem a tarefa de impor a disciplina, ou onde precisa manter o silêncio, a atitude dos estudantes não poderia ser outra a não ser a de reagir, quebrar as regras. Já a disciplina, se bem entendida, está mais próxima da liberdade. Quando essa é conscientemente exercida, o resultado é a ordem, mas não aquela ordem imposta que nega a própria liberdade. As crianças, quando em liberdade, têm muito menos ódio a manifestar do que quando são oprimidas. Enquanto não compreendermos isso, as seguintes questões serão constantes entre os educadores: quais represálias são eficientes para eliminar a indisciplina nas escolas? Como faço para que os alunos tenham o mesmo respeito que tínhamos antigamente nas escolas? Como amenizar a violência dentro da escola? Como faço para que fiquem quietos enquanto eu explico a matéria?

A pergunta correta a ser feita é: a disciplina pode ser obtida e preservada através da busca incessante por mais punições? Acredito que não. Isso depende muito mais da geração de possibilidades para o exercício de uma liberdade responsável, não só dentro, mas fora da escola. É a partir de uma verdadeira prática de cidadania que se oportunizará a formação pessoal e social de estudantes mais responsáveis pelos seus próprios atos e mais preocupados com a dimensão coletiva. Tal ação dispensa qualquer tipo de imposição normativa dos códigos de 
conduta. Mas como conseguir tal feito, se as instituições escolares raramente se constituem em espaços organizados democraticamente? Quantas escolas agem de modo colaborativo na criação, discussão, aprovação e apresentação das regras que fazem parte do seu regulamento? Se os estudantes não percebem que a escola também é um espaço deles, como vão respeitá-la? Por que respeitar regras de cuja elaboração não participaram?

A busca incessante da Escola Projeto Âncora em refletir sobre as questões acima já obteve bons resultados. No período em que observei a instituição, fui capaz de enumerar quatro elementos importantes que podem funcionar como indicativos para entender a criação e manutenção do bem-estar das relações pessoais entre os diferentes agentes:

1) tudo na escola está sujeito a mudança;

2) todas as vozes são ouvidas. Ou seja, todos os aspectos da escola são abertos para discussão, incluindo visitantes de fora da escola;

3) há um envolvimento dos estudantes para realizar seus objetivos e isso resulta na diminuição dos casos de bullying. Quando as crianças descobrem suas áreas de interesse e descobrem suas capacidades, elas não têm necessidade de violência para pronunciarem sua existência;

4) existe uma grande quantidade de grupos criados para a realização de inúmeras atividades. Estudantes e professores se organizam a todo momento de modo espontâneo para solucionar problemas ou atingir certos objetivos.

Como o Âncora não é uma "ilha" isolada da sociedade ao redor, é claro que os casos de comportamento agressivo estão presentes entre os agentes. Entre os educadores já houve discussões acaloradas. Entre educadores e familiares já ocorreram pequenas desavenças. Entre educandos, por serem mais autênticos do que os adultos, já ocorreram até mesmo agressões físicas. Isso é absolutamente normal. Faz parte do processo de convivência. Quanto à regularidade desses conflitos, posso afirmar que é muito menor do que aquela que encontrei em escolas convencionais. E alguns educadores me informaram que as ocorrências estão reduzindo ano após ano. Isso acontece porque, no Âncora, o estabelecimento da boa convivência ou da disciplina não é visto como uma responsabilidade exclusiva de um professor que precisa dominar uma "turma de bagunceiros". Ou então, em casos extraordinários de indisciplina, uma responsabilidade de outras autoridades escolares como a coordenação e a direção. Quando um conflito aparece no Âncora, os educadores interferem para tentar estabelecer um diálogo entre os estudantes envolvidos. Os educadores preferem escutar mais do que falar, assim conseguem 
proporcionar um ambiente mais receptivo para que as crianças relatem as versões do caso ocorrido. É uma relação de empatia, onde a criança envolvida, ao dialogar, começa a perceber como suas ações originaram a antipatia no outro e vice-versa.

Considero que os conflitos, quando bem direcionados, podem movimentar qualquer escola. No Âncora, constatei que as divergências e contendas sempre resultavam em uma situação positiva. Observei, em vários momentos, crianças que haviam acabado de brigar estudando juntas ou até mesmo mediando outros conflitos que aconteciam pela escola. Houve também uma iniciativa por parte dos estudantes que resultou na criação de um coletivo para pensar questões como racismo, bullying, sexualidade e gênero no ambiente escolar. $O$ grupo se formou devido à necessidade de algumas crianças que queriam auxiliar seus colegas e diminuir o preconceito dentro da escola. Eles já organizaram sessões de filmes, realizaram exposições, convocaram os pais e promoveram eventos envolvendo os assuntos mencionados. Todos as ações promovidas pelo grupo, segundo a percepção de alguns professores, vêm obtendo bastante êxito na melhoria das relações entre as crianças.

Perante os comportamentos mais agressivos de educandos que batem ou ameaçam outros, além das intervenções promovidas pelos educadores e estudantes, o auxílio da família também se faz presente. Os pais possuem livre acesso à escola e por isso ajudam acolhendo e conversando com a criança, seja esta sua filha ou não. Alguns pais que dispõem de tempo livre são convidados pela Escola para participar mais ativamente do cotidiano escolar, pensando e desenvolvendo novas estratégias para resolução de conflitos. São importantes para que as crianças tenham atitudes mais voltadas aos valores proclamados pelo Âncora. No geral, existe uma boa relação entre pais e educandos no ambiente escolar. Ninguém fala alto para chamar a atenção, ninguém grita com o outro, ninguém ofende o outro. Uma vez presenciei a chegada de uma nova criança ao Âncora e soube que os pais da mesma alertaram os educadores do projeto sobre o "histórico violento" dessa criança, que havia agredido outra criança em sua antiga instituição. Esse novo estudante foi acompanhado mais de perto, não só por esse motivo, mas também porque essa atitude já faz parte do processo comum de familiarização dos recémchegados. Qualquer pessoa que reage de forma violenta dentro ou fora do Âncora, ao chegar à instituição é tratado como uma pessoa que está precisando de ajuda e não de punição. Tal concepção mudou a história do tratamento disciplinar na Escola. 
Conforme apresentei, no Âncora se incentiva constantemente a participação das famílias. No entanto, não enxergam os pais como parceiros. Ao contrário, entendem que a escola é que deve ser uma das parceiras da família. Esse pensamento faz com que a escola não seja vista como um depósito de estudantes e dá condições para que as famílias melhorem ou desenvolvam suas habilidades educativas. A ideia é fazer com que os pais se dirijam à escola para falar e não apenas para ouvir. É uma postura ativa diferente daquela abordagem que costumeiramente é vista em outros lugares, onde a escola toma a iniciativa de marcar uma reunião de pais convocando-os para ouvir o que a instituição tem a dizer sobre seus filhos. Assim, o dispositivo chamado de "reunião de pais" opera de outra forma no Âncora. Não é algo feito para o professor dizer coisas para os pais. Lá, os pais são chamados para falarem sobre seus filhos, sobre a escola ou sobre qualquer coisa que acharem necessário.

Porém, participar não consiste apenas em intervir em reuniões, ou pertencer a uma associação de pais e mestres, embora isso também seja importante. Desse modo, quando as crianças se matriculam na Escola Projeto Âncora, os responsáveis assinam um termo de compromisso que requer a participação ativa dos mesmos na educação dos seus filhos. Tal participação, segundo um pai entrevistado, é essencial, pois “ajuda na comunicação com a escola e faz que a gente [referindo-se a ele e a esposa] tenha mais vontade de ajudar e acompanhar não só nossa filha, como também os filhos dos outros". Na opinião de uma das educadoras, "a escola só tem a ganhar com a aproximação das famílias". Para ela, "o aprendizado das crianças é potencializado com a participação ativa das famílias”, pois a ideia é que eles "sejam parte da gestão escolar, cooperando com todos os problemas de ordem coletiva".

Vale ressaltar também que os educadores realizam visitas regulares às casas das crianças, com o objetivo de estreitar os laços entre escola, estudante e família. Nas visitas, os professores também podem descobrir mais informações sobre os gostos, as inclinações, as dificuldades, as rotinas e responsabilidades de cada criança. As visitas podem ser feitas, desde que tenham o consentimento das famílias, por qualquer um, mas a Escola também dispõe de psicólogos e assistentes sociais que, conforme já expliquei, também são vistos como educadores. Na maioria das vezes, as visitas têm a finalidade de organizar melhor os combinados entre o Âncora e os pais em relação ao que esperam das crianças, pois acreditam que o processo educativo só se efetiva de modo colaborativo. Um combinado pode variar desde 
o desenvolvimento de certas atividades de pesquisa até a execução de tarefas domiciliares, como lavar o uniforme esportivo utilizado no treino.

Hoje em dia, o Âncora tem uma comissão das famílias, que atua em diversas áreas de necessidade da escola. Alguns pais também atuam como voluntários em setores como transporte, portaria, cozinha, salas de aprendizagem, entre outros. Observei também que a participação das famílias não se resume à comissão de pais ou à presença em reuniões, o que já é algo louvável comparado à maioria das escolas. Os pais também promovem as reuniões da associação que representam. Apesar dos pais dos alunos do Âncora viverem como a maioria dos pais dos alunos de outras escolas, ou seja, passarem o dia trabalhando, eles têm um envolvimento com a instituição que eu não havia visto antes em outros lugares. Percebi que muitos já conseguem compreender a proposta educativa do Âncora, inclusive alguns opinam sobre o aspecto pedagógico. Alguns pais me relataram sobre a felicidade em perceber o "avanço de seus filhos" e a "mudança de comportamento" de algumas crianças em suas casas.

No entanto, essa estreita relação entre escola e família nem sempre foi assim. O relato de vários educadores e educandos que participaram e ainda participam desse processo demonstrou a dificuldade em trazer os pais para a Escola. As buscas por estratégias e ferramentas para melhorar o envolvimento dos pais com o projeto foram intensas. Durante as reuniões promovidas pela Escola, os educadores tentavam transmitir as finalidades educativas e a filosofia da instituição para os pais. Mesmo assim, nas palavras de um educador, "as dificuldades foram grandes". Ele segue dizendo que, no início, "parecia que não falávamos a mesma língua dos pais. E, de fato, não estávamos falando. Percebemos que a nossa preocupação estava sendo falar para e não com eles". Assim, "quando mudamos nossa postura os pais foram gradativamente sendo incluídos e começaram a participar cada vez mais da escola e da educação dos seus filhos nos próprios lares".

Mesmo em uma escola que procura uma proximidade maior com os pais, como no caso do Âncora, a família ainda demonstra muita dificuldade em se adaptar a uma situação nova, onde o lugar do estudante é diferente, complexo e ambíguo. A explicação para esse fenômeno, segundo $\mathrm{Hecht}^{13}$ (2016), é que a escola ainda não passou por uma alteração vital que

13 Em 1987, Yaacov Hecht criou, junto com algumas famílias e outros educadores, uma escola diferente na cidade de Hadera, em Israel. A instituição sobrevive até hoje e atende a crianças e adolescentes de 4 a 18 anos. Nessa escola, o respeito à liberdade é visto como um aspecto pedagógico estruturante. 
a revolução dos direitos humanos demanda. Enquanto houver essa resistência, o autor diz que será um encontro difícil e complicado, que sempre acaba fazendo mal a muitos envolvidos nele. Realmente, basta atentar, como prova disso, ao número crescente de escolas em que há muitos conflitos entre pais e professores.

Outro ponto importante é que a escola tem melhorado não só a relação com a família, mas também com a comunidade em geral. Quando digo comunidade estou me referindo aos outros moradores e trabalhadores da região que não estão diretamente ligados ao Âncora, sem filhos matriculados na instituição. Desde a criação da instituição, quando ainda se tratava de um projeto assistencial, o objetivo de estreitar laços com a comunidade esteve presente. Sempre sonharam com a aplicação de uma nova proposta de transformação sociocultural do entorno, onde todos pudessem ser responsáveis pelo bem comum. Foi assim, imbuídos mais uma vez pela ideia de que o trabalho deve ser feito junto e não para a comunidade, que surgiu, no ano de 2013, o que chamaram de "Cidade Educadora Âncora". Trata-se de uma Comunidade de Aprendizagem que procura empregar novos conhecimentos e formas de cooperação para que a comunidade alcance um melhor desenvolvimento social, econômico, cultural e organizacional. Isso resulta em uma rede colaborativa de aprendizagem que possibilita estreitar as relações dentro da comunidade e desta com outros parceiros que potencializam o crescimento local.

A construção da Comunidade de Aprendizagem no Âncora se baseou no pensamento do educador brasileiro Lauro de Oliveira Lima ${ }^{14}$. No entendimento de Lima (1980), cada pessoa adulta que faz parte de uma determinada comunidade é responsável pelo futuro das crianças. Assim, a escola seria apenas um ponto de encontro, ou melhor, um centro cultural. Ele defende que a escola deve se realizar nos espaços comunitários, no lugar de se tentar trazer a comunidade para a escola. O educador entende que, se a escola é comunidade, a comunidade também é escola e, por isso, a escola não pode se reduzir a um lugar fixo murado. Lima afirma ainda que, quanto maior for a relação de subordinação, menor será a de participação, ou seja, quanto maior for a condição de cooperação do indivíduo, maior será a sua atuação dentro da comunidade.

14 Foi um importante pedagogo nascido em 1921 na cidade de Limoeiro do Norte, no Ceará. Ficou conhecido devido a sua atuação política e por ter desenvolvido o Método Psicogenético de aprendizagem. Publicou mais de 20 obras na área de educação. O autor faleceu em janeiro de 2013 no Rio de Janeiro. 
Nas palavras de Pacheco, que também foi tomado como inspiração, uma Comunidade de Aprendizagem:

é um grupo que interage entre si e estabelece relações sociais, durante um determinado período de tempo, com o propósito de aprender um conceito de interesse comum; é um projeto político-pedagógico que a escola escolhe seguir buscando sempre a máxima aprendizagem, necessária para conseguirmos uma sociedade da informação para todas as pessoas; é uma estratégia que ajuda a superar os obstáculos para o ensino universitário eficaz; é um programa desenvolvido pela secretaria de educação; grupo de pessoas que persegue propósitos comuns, com o compromisso coletivo de sopesar regularmente o valor dos mesmos, modificando-os quando tenha sentido, e desenvolvendo continuamente modos mais efetivos e eficientes de o conseguir. (informação pessoal)

Para entender o alinhamento das ideias dos educadores José Pacheco e Lauro Oliveira de Lima com a dos educadores da Escola Projeto Âncora, resgato um trecho de uma Carta mensal de setembro de 2009, quando a "Cidade Educadora" ainda estava no papel:

[...] De uns tempos para cá temos visto nascerem grupos de gente que não mora em comunidades a se organizarem em torno de um interesse comum. O aquecimento global está fazendo indivíduos que vivem solitários e fechados em seus carros, casas e condomínios, a se unirem em busca de soluções para um problema que estão entendendo como ameaçador à vida. $\mathrm{O}$ individualismo não tem futuro num mundo ameaçado e as pessoas descobrem o que os pobres já sabem: que é preciso estar unido para enfrentar um inimigo comum. Veremos um dia condomínios virarem comunidades. Um condomínio poderá se organizar para fazer em comum as compras de alimentos, ganhará no preço e no tempo. Um condomínio poderá se organizar para que uma educadora cuide de algumas crianças que não precisarão se deslocar para creches. Os moradores poderão se organizar para irem juntos para o trabalho. Poderão ter uma horta coletiva. Poderão se auto-ajudar ao conhecerem os problemas uns dos outros. Tudo isso é possível! Para se tornar realidade é preciso vontade, essa vontade só acontece quando estamos no abismo, quando a vida está ameaçada, quando estamos desesperados. A consciência de que pereceremos se não agirmos nos obriga a nos organizar. (PROJETO ÂNCORA, 2009)

Os educadores do Âncora concordam que a criação de uma Comunidade de Aprendizagem promove as condições necessárias para o estabelecimento da cidadania. Tal cidadania, segundo eles, é formada através do compartilhamento de informações e pela promoção de debates que geram um novo modo de se pensar, uma nova cultura escolar. Desse modo, ao introduzir uma visão mais prática aos conteúdos educativos, a Comunidade de Aprendizagem auxilia os estudantes a refletirem sobre os problemas vivenciados no seu bairro. "É uma fonte inesgotável de aprendizado", conforme as palavras de uma educadora. Percebi que a pretensão dos educadores do Âncora é romper com os elementos de uma tradição assistencialista que ainda paira pela instituição. Ou seja, eles não querem olhar para os indivíduos da comunidade como sendo os vulneráveis que necessitam de ajuda e esclarecimento. Procuram cada vez mais incentivar uma postura ativa na comunidade, para que 
haja agentes transformadores. Se trata de uma outra forma de solidariedade. O objetivo é que a Cidade Educadora Âncora, enquanto uma Comunidade de Aprendizagem, proporcione ao estudante experiências que lhe permitam obter consciência de si mesmo como parte de uma sociedade maior. As comunidades seriam estimuladas de modo a trabalhar a identidade do estudante, seu arcabouço de saberes, de inclinações e necessidades.

Ainda não se comprovou a impossibilidade de uma escola capaz de promover a emancipação humana. Uma escola que oferece variados recursos para mediar as diferentes realidades que a conformam, e que reconhece a diversidade dos seus componentes como uma forma de potência educacional e a desigualdade entre os mesmos como um problema político. Uma escola assim está sempre inventando e estabelecendo seu compromisso em se realizar como uma Comunidade de Aprendizagem. Tornando-se mais aliadas, as pessoas se organizam para transformar a realidade em que vivem. Os problemas e os êxitos são compartilhados entre os agentes. Qualquer tipo de situação é mobilizadora, pois na busca por soluções todos aprendem. A pedagogia desse tipo de escola declara, assim, o compromisso com uma educação que propõe uma alteração cultural baseada em princípios democráticos.

Do outro lado, não acredito nas escolas que procuram soluções dentro dos seus próprios muros. Uma escola que assim pensa aponta para uma má compreensão dos problemas e desafios que se apresentam nas comunidades. Lembro-me de quando tinha 15 anos e precisei me ausentar da escola em que estudava por um mês. Estava envolvido com um teste de futebol e precisei viajar sozinho. Me senti realizado, por viajar pela primeira vez de avião e por ficar rodeado de pessoas que admiravam o que eu sabia fazer de melhor: jogar bola. Em seguida, quando voltei para a escola, uma professora de biologia me encontrou durante o intervalo da escola e me repreendeu devido à minha ausência nesse período de 30 dias. Ela disse que dificilmente eu iria conseguir "recuperar o conteúdo". Aquilo foi pior do que uma agressão. Eu não fiquei triste por causa das lições perdidas, mas porque esperava outra atitude de uma professora que não me via havia um mês. Esperava que ela desse mais importância para as minhas experiências vividas do que para uma série de saberes que eram importantes somente para ela.

Na maioria das escolas, é grande a quantidade de exemplos como esse acima, de um lugar construído para ser alheio aos interesses das pessoas que dele fazem parte. No Âncora o que pude observar foi diferente. Quando não existe um especialista na escola, as crianças 
procuram na comunidade. Vi uma criança que queria saber mais sobre petróleo e visitou uma fábrica sob a tutoria de um engenheiro que morava perto da escola. Vi um rapaz que queria aprender mais sobre mecânica e por isso começou a fazer um pequeno estágio de três horas diárias em uma oficina mecânica do bairro. Vi também mutirões para resolver o problema do lixo. E soube de uma história, a que mais chamou minha atenção, sobre um grupo de meninas que tiveram a iniciativa de produzir roupas para bonecas e receberam a ajuda de uma costureira que era avó de uma das meninas. A senhora resolveu, mesmo sem nunca ter ensinado ninguém formalmente, ensinar as meninas no seu próprio brechó. Como o brechó ficava numa rua bastante movimentada, as pessoas que passavam por lá se interessavam pela costura e solicitavam aulas da avó. Um certo dia, o locador exigiu que a propriedade fosse devolvida devido ao atraso de aluguéis. Houve uma mobilização dos envolvidos para ajudar com as contas e a senhora conseguiu negociar a dívida e seguir com as aulas de costura. Esse é um verdadeiro exemplo da interação entre escola e comunidade.

As diferentes pessoas, em suas comunidades, poderão aprender novos saberes, desenvolver novos ofícios, refletir e agir de forma mais sustentável, buscar novos modos de vida e avaliar as ações e expectativas dos seus representantes. Com isso, espera-se que as pessoas contribuam umas com as outras, viabilizando de modo coletivo ambientes de aprendizagem em que todos tenham a capacidade de ser educadores comunitários e, acima de tudo, propagadores de iniciativas em outros espaços educacionais, não escolares. Esse protagonismo comunitário rompe com a perspectiva costumeiramente presente nas escolas, onde a transmissão de saberes é algo exclusivo da figura docente, cabendo ao restante das pessoas aceitar e incorporar o conhecimento obtido.

O Âncora, por exemplo, está inserido em uma comunidade com pessoas adeptas de diferentes religiões (catolicismo, protestantismo, espiritismo, umbanda, candomblé, budismo), como também ateus e agnósticos declarados. Que tem a escola a ver com a religião? Muito. Embora a Escola Projeto Âncora seja uma instituição laica, ela não se omite nem nega que a crença é parte importante do desenvolvimento pessoal de cada indivíduo. Sempre que surge alguma coisa relacionada a um determinado aspecto de ordem religiosa, os educadores procuram trabalhar a questão partindo das inquietações da própria criança. Apresentam também a questão do respeito à diversidade religiosa entre as crianças. Um exemplo disso é a ausência de eventos com conotação religiosa na Escola. Caso algum tipo de festa não seja abordado do 
ponto de vista cultural e regional, as crianças podem optar por não participar, ou propor alguma adequação para ser votada em assembleia.

A esta altura já deu para perceber que a Escola Projeto Âncora é governada pelo princípio de autonomia, democrático em sua forma. O desenvolvimento da autonomia é o principal objetivo da instituição. Assim, todas as reflexões e ações da Escola são norteadas para isso. Como a autonomia não é algo que possa ser imposto, ela se desenvolve em diversos ambientes e em diferentes momentos. Creio que a escola sem autonomia não deveria nem ser classificada como uma escola progressista. No entanto, esse discurso de uma educação para a autonomia se transformou em um clichê onde as práticas educacionais raramente se alteraram. Desse modo, é natural que uma crítica conservadora se antecipe e aponte que essas "inovações progressistas" não surtiram efeito na escola e que é preciso retomar as práticas de costume. Porque, apesar do aparente consenso, as práticas ainda estão distantes do discurso.

No Âncora, tudo quanto se relacione com a sociedade, com o grupo escolar ou com a vida dos envolvidos, inclusive as formas de resolução pelas transgressões, é resolvido nas Assembleias Gerais. Segundo a coordenadora, "o projeto busca a autonomia na autonomia". Daí que qualquer atividade escolar, se estiver associada a responsabilidade e colaboração, pode se tornar uma lição de autonomia - algo que, de uma forma ou de outra, a maioria das escolas deseja porém poucas têm conseguido. O Âncora segue, cada vez mais, na direção contrária de uma cultura autocrática, de modo a propiciar e incentivar a participação de todos, em tudo. A gestão da Escola é horizontal e se apoia no exercício participativo das decisões, em que os debates sobre os problemas procuram mecanismos viáveis para a concretização dos objetivos coletivos propostos. Claro que a mudança de gestão que se almeja tem sido um processo difícil, que tropeça em vários obstáculos. Contudo, os educadores acreditam que toda mudança acontece de maneira lenta e gradual e, por isso, não desistem de agir nessa direção.

Dentro dessa perspectiva de uma educação engajada e preocupada com a atuação social dos estudantes, temos a Assembleia dos Estudantes que é realizada toda sexta-feira no período matutino. Não existe votação, somente consenso. Por esse motivo, uma mesma pauta pode se estender durante meses, como a da questão do uso do celular, que abordei no capítulo anterior. Ser estudante matriculado é a única condição de participação, mas a participação na assembleia não é obrigatória. As assembleias são organizadas exclusivamente pelos educandos. Não existe interferência dos professores no processo decisório, o que não impede a consulta de 
professores para casos excepcionais. As reuniões semanais são feitas na quadra poliesportiva. Lá, existe uma mesa composta por quatro crianças eleitas: duas secretárias, uma presidente e uma escrivã. O presidente se encarrega de conduzir a assembleia. As outras crianças dividem tarefas, como escrever a ata da assembleia ou organizar a ordem de quem vai falar.

A assembleia é norteada por um princípio, uma frase de Voltaire, estampada na mesa central e na "cabeça" dos participantes: "posso não concordar com nenhuma das palavras que você disser, mas defenderei até a morte o direito de você dizê-las". Guiados por esse preceito, os estudantes discutem seus direitos e deveres existentes ou constroem novos. Também debatem projetos em andamento, fazem avaliações, apresentam trabalhos, refletem sobre questões extraescolares e planejam festas de aniversário. É um momento marcado exclusivamente pela presença dos estudantes para a tomada de decisões ou adequação às normas que já foram criadas por eles. As regras da Escola, os chamados combinados, advêm daquilo que é discutido e aprovado pela assembleia. São regras instituídas para auxiliar na manutenção e na convivência no espaço escolar. Trago alguns combinados das assembleias a que compareci: 1) Sobre sumiços: procurar o pertence antes de comunicar o sumiço do mesmo, se soubermos quem pegou o pertence conversaremos em particular apenas com a criança e com os responsáveis, ter mais rodas de reflexões sobre roubos e consumismo; 2) Sobre limpeza: conscientização coletiva para ajudar na limpeza e organização dos espaços, não aceitar situações de bullying referente a esse assunto; 3) Sobre bullying: as pessoas que praticam bullying serão encaminhadas, pelo tutor, ao "cine bullying" para refletir sobre seus atos; 4) Sobre o comportamento em alguns espaços: não pode correr, falar alto ou pular a janela nos espaços de leitura.

A assembleia foi o dispositivo mais intrigante que acompanhei. Imaginem cerca de cem crianças reunidas em uma quadra poliesportiva coberta, em silêncio, pedindo a palavra e aguardando pacientemente sua vez de falar. Nos primeiros dias cheguei a pensar que eram crianças diferentes das demais, excepcionalmente bem educadas. Mas basta observar crianças na escola próxima ou as próprias crianças do Âncora brincando, para perceber que criança é criança em qualquer lugar do mundo: sabem fazer barulho, algazarra, como qualquer criança. Com o passar do tempo, percebi que o comportamento das crianças no Âncora é uma questão cultural, não do país, mas muito específica daquela escola e da forma como se vive ali. Como determinadas condutas são decididas pelas próprias crianças, elas são as primeiras responsáveis pelos problemas disciplinares da Escola. Por isso a assembleia é levada muito a sério pelas 
crianças. Não encaram como uma brincadeirinha: sabem que, quando algo chega em um consenso, todos precisarão cumprir aquilo que foi decidido. Enquanto é comum em outras escolas as leis serem determinadas e aplicadas somente para os estudantes (e só eles podem apresentar algum problema de ordem disciplinar), no Âncora as leis são feitas para todos e, à vista disso, já aconteceu tanto estudantes quanto docentes que violaram os combinados terem sido trazidos a vários comitês para avaliação das suas condutas.

Outro aspecto que percebi foi que as atitudes vaidosas das crianças mais velhas são raras no Âncora. Falo das mais velhas pelo fato de ser comum elas tentarem se impor às mais novas. Qualquer sinal de um comportamento mais espalhafatoso ou metido encontra uma reação contrária por parte da maioria. Na primeira assembleia de que participei como um observador atento, vi um menino de uns 14 anos que procurava se exibir, talvez pela minha presença, de qualquer maneira: erguia os braços, assoviava e fazia comentários longos sem qualquer relação com o que estava sendo debatido naquele momento. No entanto, suas tentativas foram abafadas rapidamente. Uns solicitavam com gentileza para que ele se sentasse. Outros, mais impacientes, davam broncas e o obrigavam a ficar quieto. Notei que as crianças se faziam mais autênticas quando algo as incomodava.

As pautas das Assembleias dos Estudantes são diversas, definidas de acordo com as necessidades que se apresentam. Tais necessidades são colocadas, para facilitar, por meio de um mecanismo de "não acho bom / acho bom". Trata-se de um quadro branco, onde os estudantes podem escrever, a qualquer momento, as coisas de que eles gostam, que aceitam e querem que evoluam, ou então as coisas de que não gostam, que não aceitam e querem que sejam alteradas. Também é comum ver cartazes espalhados pela escola manifestando suas revoltas ou apoiando suas causas. Um que me chamou a atenção, pendurado na porta de uma das salas, dizia assim: “o que você faz quando ninguém está olhando?”. As pautas podem estar relacionadas a algum problema da escola. Por exemplo: as salas estão sujas, a gritaria nos espaços de leitura está intensa, os pratos de comida estão sendo deixados sobre a mesa. Ou, então, as pautas também podem atender a uma demanda específica, como: devemos discutir mais sobre sexualidade, sobre racismo etc. Antes de iniciar a assembleia, há o que chamam de "roda de reflexão", que serve para adicionar as pautas que serão deliberadas pela assembleia. A presença na roda de reflexão é obrigatória. A mesa responsável reúne as pautas consensuais e as leva para a assembleia. Se não for possível chegar ao consenso de uma pauta, ela retorna na semana seguinte ou quantas vezes forem necessárias. 
Na minha opinião, esse dispositivo que reúne as crianças para decidir sobre os rumos da Escola, chamado de assembleia, possui um valor maior do qualquer assunto curricular previamente estipulado. A assembleia é um local excelente para se treinar a oratória. A maior parte das crianças no Âncora se comunica muito bem e sem qualquer timidez. Ouvi muitos discursos sensatos proferidos por crianças que ainda nem sabiam escrever direito. O que faz também com que as crianças argumentem de igual para igual com os adultos, sem medo e sem tentar agradá-los. Falam o que vier "na telha". Claro que todos os educadores do Âncora são solidariamente responsáveis pelas decisões tomadas pelas crianças, e pactuam cumprir e fazer cumprir o que é decidido nas Assembleias dos Estudantes. Na entrevista que um dos educadores concedeu, me disse que "todos na Escola lutam para que as decisões não caiam nas mãos da maioria e acabem dominando a minoria”. Segundo ele, "entrar em consenso é mais lento e mais trabalhoso, porém mais vantajoso do ponto de vista da qualidade das relações".

Esse mesmo educador seguiu com algumas recomendações para aqueles que desejam melhorar as relações pessoais na escola onde trabalham. Primeiro, segundo o professor, os que desejam mudar devem iniciar com a seguinte pergunta: “nós escutamos uns aos outros?”. Depois, segue o educador, “precisam saber se estão dispostos a enfrentar os 'perigos' da liberdade". De fato, pautar-se em princípios democráticos não é tarefa fácil. É necessário que a equipe escolar esteja receptiva a ouvir as reais necessidades das crianças e tenha a coragem de aceitá-las. Aceitar no sentido de compreender o significado da vivência baseada em relações mais horizontais. Entender também que, às vezes, as crianças poderão votar contra os valores do professorado. Entender que há crianças que não têm respeito e consideração pelas minorias e, assim cometem infrações sobre os direitos alheios. Entretanto, são riscos que valem a pena, pelas oportunidades de aprendizado que são geradas. Esse é um papel de extrema importância que os adultos possuem no diálogo multigeracional no interior das escolas. Mesmo que crianças menores ainda não entendam o significado teórico de democracia, é importante que cresçam em uma cultura democrática. 


\subsection{Procedimentos de ensino-aprendizagem}

A Escola Projeto Âncora funciona em período integral das 7h às 16h30. Atualmente, 146 estudantes fazem parte do projeto. A maioria das crianças permanece na instituição em tempo integral, mas, como isso não é uma obrigatoriedade, cada uma tem a possibilidade de ajustar sua permanência de acordo com suas necessidades. As crianças que moram mais perto da Escola, em geral, chegam mais cedo, e as que moram mais longe chegam um pouco mais tarde. A flexibilização de horários é um combinado entre a criança, a família e a Escola. Como os educandos são provenientes de famílias em situação de vulnerabilidade social, a maior parte dos pais opta por deixar os filhos integralmente na Escola, reduzindo assim a exposição dos mesmos a algum tipo de risco ou violência. Contudo, a prática costumeira, presente em outras escolas, de obrigar a criança a despertar de madrugada para estudar até as $12 \mathrm{~h}$ e ceder lugar para outra turma, não existe no Âncora.

A criança inicia seu dia no Âncora a partir da construção de um planejamento. Tratase de um exercício de organização diária. Ao chegar à Escola, a criança define junto ao seu tutor quais serão suas atividades do dia, o que inclui oficinas, encontros com colegas para pesquisas e estudos, encontros com possíveis visitantes, participação em algum grupo de responsabilidade, brincadeiras, pausas para descanso, atividades esportivas, atividades comunitárias, refeições, entre outras coisas. Além da execução do plano do dia, nesse momento também são feitas rodas de reflexão com outros educandos para conversarem sobre os anseios e acontecimentos comuns de suas vidas ou sobre assuntos relacionados ao desenvolvimento de alguns projetos de aprendizagem. Não existe um assunto estabelecido para cada roda: educadores e educandos apenas identificam suas necessidades e as compartilham com os demais.

Com o planejamento diário finalizado, os estudantes se dirigem para os diversos espaços da Escola com o objetivo de realizar aquilo que foi concebido. As atividades vão se desenrolando a partir das necessidades de cada criança ou de cada grupo de crianças. Por exemplo: se um grupo deseja aprender a tocar um instrumento, eles se reúnem e entram em um acordo quanto ao horário. Mas vale lembrar também que há algumas atividades que acontecem em horário fixo, como as assembleias, as visitas e as refeições. As Assembleias dos Estudantes ocorrem às 9h das sextas-feiras, e as Assembleias Gerais ocorrem às $17 \mathrm{~h}$ das segundas-feiras. 
Os visitantes são recebidos às $9 \mathrm{~h}$ das quartas-feiras. E as três refeições diárias se dão entre $9 \mathrm{~h} 15$ e $9 \mathrm{~h} 30$, entre $12 \mathrm{~h}$ e $13 \mathrm{~h}$ e, finalmente, entre $14 \mathrm{~h} 45$ e $15 \mathrm{~h}$.

Cada criança possui um cotidiano bem diferente. Algumas preferem as atividades de laboratório, enquanto outras gostam mais das atividades ao ar livre. Fica fácil perceber a multiplicidade dos gostos e inclinações quando as crianças são livres para escolher. Como não existe aula no Âncora, a construção do conhecimento está espalhada por todas as partes do espaço escolar. É comum encontrar crianças por todos os cantos: na sala de música, embaixo de uma árvore, andando de skate. Há também a possibilidade de encontrá-las participando das oficinas propostas por educadores, voluntários ou as próprias crianças. Tem oficina de yoga, de banda de música, de anatomia, de ateliê aberto, de futsal, de basquetebol, de jogos dramáticos, de contação de histórias e de meditação, entre outras. Quem assim desejar basta anunciar que tem interesse em abrir uma oficina e convidar os demais a aderirem. Se há uma oficina que é quase unanimidade entre as crianças, é a oficina circense. A maioria adora participar das atividades do circo. No picadeiro, os estudantes e até os ex-estudantes são tutorados por uma artista que está no Âncora desde 1996. Para ela, o circo é “uma importante ferramenta de educação que ajuda a criança a trabalhar em conjunto, a combater a inibição e a melhorar a sua autoestima". Questionada sobre a preferência das crianças pelas atividades circenses, ela disse: “não sei ao certo, mas penso que tem a ver com a própria essência do Âncora. O circo chegou aqui antes do projeto se tornar uma Escola. Muitos já frequentavam o circo antes de serem estudantes do Âncora. Acho que é esse o motivo...”.

Todos os dias, ao final do dia, cada criança procura seu tutor para conversar sobre o que foi e o que não foi possível cumprir dentro do seu planejamento. É uma espécie de autoavaliação diária, onde as crianças podem observar melhor o que fizeram, o que sentiram, o que aprenderam. Isso serve para que também possam reconhecer as distâncias entre aquilo que é planejado e aquilo que é executado. Às vezes, mesmo sabendo que não será possível realizar a grande quantidade de ações propostas, os educadores não interferem, de início, e esperam esse momento da autoavaliação para apontar e equilibrar melhor as escolhas das crianças. Dessa forma, no dia seguinte, as escolhas das crianças vão se tornando mais realistas e mais exequíveis. Presenciei a elaboração do plano diário de uma criança que ainda não tinha muita noção de organização do tempo e que resolveu elaborar as atividades da seguinte forma: $7 \mathrm{~h} 40$ brincar, $8 \mathrm{~h} 10$ roda de reflexão, 9h plano do dia, 9h30 brincar, 10h oficina, 10h quadra, 11h30 oficina, 12h almoço, 12h30 amigo do dente, 13h descanso, 13h30 circo, 14h quadra, 15h avião 
de papel, 16h saída. Como se pode ver, nesse plano houve um excesso de atividades e também um conflito de horário entre as mesmas. Isso é comum acontecer e perfeitamente compreensível pelos educadores, pois o que realmente importa é que o estudante desenvolva a habilidade de organização e tenha cada vez mais responsabilidade com o cumprimento das atividades propostas.

Outro tipo de planejamento existente é o plano quinzenal. Este diz respeito aos passos necessários para a construção de um roteiro de pesquisa que está relacionado ao desenvolvimento do projeto de aprendizagem de cada criança. O plano de estudos quinzenal é construído em um diálogo entre a criança e o educador. A regra primordial do plano é o interesse. A criança escolhe aquilo que deseja descobrir, estudar. O educador também pode sugerir assuntos e provocar a curiosidade do estudante. Isso demonstra que o educador não se coloca de forma passiva durante o processo, ele não é um mero apreciador que apenas consente com os desejos do estudante. No período em que lá estive, não acompanhei nenhum plano elaborado de modo solitário. A duração de um plano é de 15 dias mas, caso seja necessário, esse tempo pode ser alterado sem nenhum problema. Aquilo que não foi atingido no tempo estipulado se transforma em objetivo do próximo planejamento. Aliás, precisar de mais tempo é algo bastante comum entre as crianças e extremamente respeitado pelos educadores: significa apenas que não deu tempo. Não existe qualquer tipo de recriminação por parte dos educadores; o ritmo de aprendizagem de cada estudante é bastante respeitado. Todos os educadores do Âncora são guiados pelo princípio de que cada criança necessita de um tempo específico para aprender. Esse preceito também está amparado pela Carta de Princípios da Escola:

\footnotetext{
[...] se não somos todos iguais por que temos que aprender do mesmo modo, ao mesmo tempo, por que tratar as crianças como tábulas rasas, recipientes vazios que devem ser preenchidos por conteúdos? Não compactuamos com um modelo que exige, que força cada criança e cada jovem a se adequar a uma idealização, mediana e abstrata, do que deveria vir a ser um aluno. Para nós, cada criança é um indivíduo único e deve ser tratado como tal, não nos interessam as padronizações convencionais, idade, séries, gênero. O que nos importa são seus interesses, suas necessidades. Descobrir e encorajar suas aptidões e potencialidades, respeitando sempre sua história e sua cultura. (PROJETO ÂNCORA, 2012)
}

O roteiro de aprendizagem (Quadro 2) traça nas diferentes áreas de conhecimento um certo caminho que a criança deve percorrer para responder suas perguntas. Começa com questões básicas como: o que vou fazer? O que vou aprender? Quais serão as minhas responsabilidades durante o processo? Desse modo, coloca-se dentro do roteiro as atividades de modo a integrar as várias áreas do conhecimento. Nessa fase, o educador estimula a criança 
a escolher temas que são relacionados à sua própria vida, ao seu bairro, à sua comunidade, à sua escola. Assim, as diversas situações do universo da criança são trazidas para o cotidiano escolar. Dessa forma, os conteúdos disciplinares são adicionados espontaneamente ao roteiro, à medida que se demonstram úteis para o desenvolvimento do mesmo, fazendo com que o aprendizado desses conteúdos não seja desvinculado da realidade, sem um propósito definido.

Para execução do roteiro, os estudantes podem consultar os livros da biblioteca, realizar experiências nos laboratórios, fazer pesquisas na internet, promover trabalhos de campo e consultar seus educadores, familiares ou colegas. Fazem aquilo que for preciso para responderem às suas curiosidades. Após essa fase, cada estudante organiza melhor seus textos, descreve e elenca os elementos obtidos durante a investigação e registra o que colheu das fontes consultadas. Por fim, as crianças avaliam aquilo que foi feito para verificar se tudo ocorreu conforme planejado, e compartilham aquilo que aprenderam umas com as outras.

Quadro 2: Exemplo de um roteiro de aprendizagem.

\begin{tabular}{|c|c|c|c|}
\hline $\begin{array}{c}\text { Atividades } \\
\text { Sistema Genital Feminino }\end{array}$ & Início & Fim & Avaliação \\
\hline O que é clitóris? & $01 / 04 / 2018$ & $02 / 04 / 2018$ & - \\
\hline O que é menopausa? & $03 / 04 / 2018$ & $04 / 04 / 2018$ & - \\
\hline Ciclo menstrual & $07 / 04 / 2018$ & $08 / 04 / 2018$ & - \\
\hline Como amenizar a cólica? & $09 / 04 / 2018$ & $10 / 04 / 2018$ & - \\
\hline Hímen e virgindade & $11 / 04 / 2018$ & $12 / 04 / 2018$ & - \\
\hline Assistir documentário Miau & $13 / 04 / 2018$ & $13 / 04 / 2018$ & - \\
\hline Convidar pessoas para assistir & $14 / 04 / 2018$ & $14 / 04 / 2018$ & - \\
\hline Fazer debate sobre o filme & $15 / 04 / 2018$ & $15 / 04 / 2018$ & \\
\hline
\end{tabular}

Fonte: Organização própria a partir de dados coletados em campo.

Os educadores assumem que a Escola Projeto Âncora opera na inversão da lógica do que se costuma fazer nas outras escolas, pois se parte das inquietações dos estudantes para se chegar aos saberes elencados pelo que chamam de "currículo obrigatório". É a partir das "necessidades e curiosidades dos estudantes que conseguimos alcançar o currículo nacional obrigatório sem ter partido dele", disse um educador. Apesar da preocupação com o cumprimento das normas curriculares ser menor no Âncora, a mesma não está ausente, assim como em grande parte das escolas pelo Brasil. Entendo que é possível discutir a questão 
curricular como uma organização de atividades de aprendizagem para dirigir um processo educativo, mas falar sobre currículo como um documento formal e obrigatório é falar sobre algo que não existe. O último e único currículo obrigatório que tivemos acabou junto com o fim da ditadura militar ${ }^{15}$. O que temos, hoje em dia, são parâmetros facultativos que sugerem um recorte de assuntos que se julga serem importantes para o desenvolvimento de habilidades e competências em educação escolar. Realmente, não entendo a origem desse empenho em ter que cumprir os conteúdos presentes no currículo. Certa vez ouvi o seguinte diálogo, na sala dos professores de uma escola paulistana em que trabalhei: "Nossa! Você ainda está na página 60 do livro? Eu já consegui chegar na 80. Você é muito demorado. Perde muito tempo explicando as coisas. Eu falo uma vez só. Quem ouviu, ouviu. Senão, depois, chega no final do ano e a gente não consegue dar conta de todo o conteúdo do currículo”.

Por mais que no Âncora a preocupação manifestada no diálogo acima não esteja tão presente, os conteúdos da Base Nacional Comum Curricular (BNCC) também são seguidos pela Escola. Todavia, não são apresentados para as crianças da forma como foram enunciados pelo documento oficial. Os conteúdos são traduzidos em objetivos; ou seja, não é simplesmente anunciado como "relevo brasileiro", e sim como "compreender e identificar as formas presentes no relevo brasileiro". Assim o estudante saberá que, ao estudar esse tema, ele precisará adquirir tal objetivo. Procura-se sempre o máximo possível de objetividade e ação prática para que o estudante seja capaz de elaborar algo com o conhecimento apreendido. O currículo também é considerado pela Escola como um conjunto de atitudes e competências que, ao longo da trajetória escolar, e de acordo com as suas inclinações e potencialidades, os educandos deverão adquirir e desenvolver. Desse modo, o conceito de currículo passa a ter uma dupla dimensão: o currículo objetivo e o currículo subjetivo. O primeiro consiste em um perfil, uma meta, um horizonte de aprendizagens que precisam ser alcançadas. $\mathrm{O}$ segundo currículo diz respeito ao desenvolvimento pessoal do estudante: é um percurso único a ser seguido que resulta em um conjunto de aquisições de cada educando. Essa forma de organização do trabalho pedagógico foi explicada por uma das educadoras do projeto da seguinte forma:

A gente [educadores] realiza uma reflexão junto à criança, explicando que, apesar da liberdade que ela tem de escolher quando e como aprender determinado assunto, nós temos um currículo a ser cumprido ao fim de nove anos. Mas, como nossa relação

15 No início da década de 1970, durante o regime militar, verificava-se no Brasil uma crescente preocupação com a elaboração de currículos oficiais para a educação básica. O crescimento populacional brasileiro e o aumento da demanda por vagas na escola pública, a ampliação da rede de ensino, "forçou" a elaboração de um currículo mínimo para orientar a ação docente no ensino básico. 
com as crianças é mais próxima do que aquela que se pode construir em uma escola tradicional, a gente busca entender a raiz da recusa e procurar alternativas para superar esse obstáculo. Normalmente essa recusa não está ligada ao conteúdo em si, mas sim em suas relações: de amizade, familiares, ou mesmo traumas vindos de outras escolas e vivências desconfortáveis que, na sua cabeça, estão ligadas a determinada área do conhecimento. Conseguimos encontrar soluções na vertente da reflexão, da conscientização, do amadurecimento pessoal, muito mais do que na imposição. A relação de confiança que é possível construir nessa prática é de tal forma que situações como a relatada por você são muito raras. Normalmente, quando uma educadora evidencia uma necessidade da criança e propõe maneiras de supri-la, não existe resistência. A educanda reconhece que, se esse é o caso, existe um sentido. Da mesma maneira, quando a criança propõe algo que lhe faz sentido, ela sabe que será acolhida e auxiliada para atingir seu objetivo. Mais do que isso, aqui buscamos o retorno do desejo pelo conhecimento, algo que é tão natural da criança. Aquela típica reclamação da professora pela apatia da aluna não tem lugar quando esse desejo, que foi reprimido, desabrocha. $\mathrm{O}$ desejo pelo aprender não tem objeto. (informação pessoal)

O acompanhamento do percurso curricular é permanente e individualizado, cabendo, principalmente, ao educador-tutor a organização de todos os registros. Quando uma criança precisa sair do Âncora, ela leva consigo uma espécie de portfólio contendo a descrição pormenorizada do seu processo de aprendizagem. Como em outras escolas é comum privilegiar o tão conhecido histórico escolar baseado em notas, a secretaria também se encarrega de confeccionar esse documento para não prejudicar a criança. Portanto, a Escola deixa claro que esse tipo de documento não tem a menor relevância e não se alinha à sua concepção de aprendizagem. "Recebemos em 2012, com o início da Escola, inúmeras crianças com históricos escolares correspondentes ao Ensino Fundamental II, sem saber ler e nem escrever", disse a fundadora. O que comprova que a prática de seriação segundo a faixa etária não é garantia de aprendizagem. Creio que a prática de considerar os estudantes como um coletivo uniforme leva à criação de currículos que dependem do conteúdo e da idade em detrimento da singularidade de cada indivíduo.

Nesse sentido, a Escola Projeto Âncora possui critérios diferentes para a organização dos estudantes. Não há um educador para cada turma, não há classes e nem distribuição de estudantes por ano de escolaridade. Somente por razões de operacionalidade, a Escola se organiza em diferentes núcleos que correspondem a etapas coerentes de desenvolvimento pessoal e social dos estudantes. São três: Núcleo de Iniciação, Núcleo de Desenvolvimento e Núcleo de Aprofundamento. Na Iniciação, as crianças desenvolvem atitudes e competências básicas para integrar a comunidade escolar, de modo mais equilibrado, e trabalhar a questão da autonomia. No Desenvolvimento, os estudantes ampliam as competências básicas adquiridas na fase anterior, procuram atingir certos objetivos nas diferentes áreas do conhecimento e aprendem a gerir o tempo escolar com maior responsabilidade. No Aprofundamento, os 
estudantes desenvolvem projetos complementares de extensão e se envolvem em cursos de profissionalização com o assentimento das respectivas famílias. Em nenhuma fase a idade é levada em conta. Para os educadores, são apenas diferentes fases de prontidão para o trabalho autônomo. E, diferente do que acontece em outras escolas, as crianças podem estudar o conteúdo que desejarem independente da fase de pertencimento. No Âncora, não há a crença de que existe um conhecimento compatível com cada faixa etária. Por isso, os educadores não se cansam de explicar aos visitantes da Escola que essa divisão de fases não representa uma progressão: é simplesmente um momento do desenvolvimento do estudante.

As crianças se encaminham para a Iniciação quando se matriculam na Escola, seja porque precisam ser alfabetizadas ou porque acabaram de chegar e precisam se adaptar aos princípios do Âncora. Atualmente, a Iniciação conta com estudantes de 4 a 15 anos, que interagem e dividem o mesmo espaço com as crianças de outras fases, porém são tratadas de acordo com suas necessidades específicas. São objetivos da Iniciação: 1) conseguir se organizar no espaço e tempo, com auxílio quando for necessário; 2) conquistar independência em relação aos cuidados pessoais; 3) participar ativamente dos momentos coletivos; 4) resolver os seus próprios conflitos de modo positivo; 5) compreender e buscar agir de acordo com os valores decididos em Assembleia; 6) perambular pelos diferentes espaços escolares de acordo com os combinados; 7) ter independência para ler e realizar suas pesquisas; 8) conceituar número, saber ver as horas, ter noção das grandezas do cotidiano e dominar as operações matemáticas básicas. A Iniciação tem como objetivo principal contextualizar o estudante sobre os usos e costumes vigentes na instituição. Os educadores assumem que os estudantes não nascem prontos para a autonomia e por isso precisam ser orientados para tal. Nessa fase, a intervenção dos educadores nas atividades dos educandos é mais frequente e diretiva. Os estudantes precisam entender, nesse momento, que as relações com outras pessoas são o que realmente importa. Saber ouvir uma opinião contrária, saber se movimentar pelos espaços sem atrapalhar os demais, saber lidar com seus colegas e agir afetivamente quando se é contrariado são aspectos, na visão da Escola, tão importantes quanto produzir um bom texto. Assim, sempre que uma criança entra em conflito com a cultura escolar, é orientada a retornar à Iniciação para relembrar os acordos ali estipulados.

No Núcleo de Desenvolvimento, os estudantes se organizam com mais autonomia para cumprir seus compromissos. É nessa fase que os roteiros de aprendizagem são trabalhados de forma mais intensa. Aqui as crianças já estão entrosadas com as normas e valores da instituição, 
circulam com mais responsabilidade pelos espaços e, além disso, estabelecem relações mais solidárias com seus pares. É comum que as crianças se tornem mais ativas durante as assembleias e outras reuniões coletivas. Nesse momento, também, tudo aquilo que é aprendido na Escola começa a refletir de forma mais evidente em casa. Há crianças que ajudam os pais a planejarem as tarefas de casa, a calcularem as finanças e até mesmo a manterem um equilíbrio durante as discussões conjugais. Quando eu estava no Âncora, 22 estudantes faziam parte do Desenvolvimento. Um desses estudantes, de 13 anos, me relatou que tinha "pavor de estudar" na escola em que foi matriculado antes de vir para o Âncora. "Lá todos diziam para mim que eu não seria nada na vida se eu não mudasse de postura. Estudar pra mim era um sacrifício enorme. Aqui me sinto livre e desenvolvi o prazer em estudar. É sério mesmo. Eu gosto de aprender coisas novas. Nunca pensei que fosse dizer isso.” Outro estudante, que também fazia parte do Desenvolvimento, me disse que o que mais gostava era a liberdade de poder circular por vários ambientes; "e aprender o que eu quero, quando quero", informou.

As crianças que pertencem ao Núcleo de Desenvolvimento, apesar de serem mais responsáveis, ainda necessitam de auxílio para a formulação e organização das suas pesquisas e estudos. Para adentrar o Núcleo de Aprofundamento, o estudante precisa demonstrar uma compreensão satisfatória dos processos de autoplanejamento, autoavaliação, trabalho em grupo e desenvolvimento de projetos. É um momento que representa a maturidade e o domínio daquilo que foi aprendido nas etapas anteriores. Como a liberdade e a responsabilidade são maiores, nessa fase são desenvolvidos inúmeros projetos autônomos pelos estudantes. Além dos jovens terem interiorizado os valores do Âncora, também auxiliam de modo mais efetivo seus colegas a alcançarem seus objetivos. O relato de uma estudante comprova essa informação: "quando você tem curiosidade você aprende; se você não tem, acaba não fazendo ou se desmotivando. E a maior prova quando você aprendeu é quando você ensina o outro". Outro ponto importante é que o aprofundamento é uma fase que está em permanente construção pelos próprios estudantes. Como o conhecimento não tem limites, eles não enxergam esse Núcleo como o fim do aprendizado. "Eu me surpreendo comigo mesma e com meus colegas pelo tanto que a gente cria aqui [Aprofundamento]. Me sinto muito seguro em relação ao meu aprendizado e por isso ajudo bastante os outros", relatou outro estudante do Núcleo de Aprofundamento. Por esse ângulo, o depoimento da coordenadora do projeto também é bastante esclarecedor: 
conteúdos previstos para o Ensino Médio numa escola convencional. O contrário também é válido, se tem uma criança com uma idade mais avançada e precisa de um conteúdo previsto para séries iniciais ela também será atendida. Não tem aquela coisa de somar uma prova com outra e adicionar um trabalho e mais um ponto positivo e, pronto, você passou de ano. Aqui ou aprende ou aprende. Não nos satisfaz uma outra condição. Se cada um tem um tempo para aprender, então não posso determinar um tempo pra ninguém. (informação pessoal)

Como não existe seriação, não existe reprovação. Os professores se reúnem e decidem coletivamente qual aluno apresenta as condições necessárias para mudar de fase. Não se trata de uma ordenação de estudantes em lugares específicos, mas sim de um processo que garante o convívio desses com um conjunto de dispositivos que auxiliam nos seus respectivos percursos de aprendizagem. Essa mudança de fase é determinada através de uma autoavaliação ou então é realizada pela indicação do próprio educador-tutor. E isso pode acontecer a qualquer momento. Somente é necessário desenvolver algumas habilidades e assumir algumas condutas (escrita, leitura, operações básicas, responsabilidade, respeito). Às vezes alguns estudantes optam por não trocar de Núcleo, porque não se consideram aptos ou então porque ainda não desejam cumprir novas responsabilidades. O tempo de permanência do estudante em um Núcleo dependerá do seu grau de autonomia, o que consiste em um processo único e individual. O desenvolvimento de cada um acontece de forma gradual, com possíveis movimentos de idas e vindas entre os Núcleos, até que a criança de fato se aproprie dos valores. Objetivamente, cada criança possui um período de nove anos para permanecer na Escola, que corresponde a Educação Infantil e Ensino Fundamental I e II. Segundo um educador, "sobra tempo para que as crianças aprendam durante os 9 anos". No entanto, os que necessitam de mais tempo "terão mais tempo e ponto". Tal abordagem permite que se trate de forma personalizada cada caso. Assim, não há espaço para uma decisão arbitrária tomada em nome de um grupo de estudantes.

A Escola Projeto Âncora possui também autorização para implantar o Ensino Médio, o que aumentaria o tempo de permanência das crianças de 9 para 12 anos, mas o processo ainda está em etapa de consolidação. Por isso, ao chegar nesse momento, as crianças saem do Âncora e migram para outras escolas da região e, por incrível que pareça, elas se adaptam. Talvez isso esteja relacionado ao fato de que os educandos conquistaram autonomia e reuniram condições necessárias para se adaptarem a novas realidades. Os educadores também são responsáveis nesse processo de transição. Procuram simular acontecimentos característicos das escolas convencionais. Aplicam provas seguindo as regras comuns de penalização e proibição de auxílios dos colegas. Discutem sobre a questão da reprodução que está escrita no livro didático para se obter uma boa nota. Falam também sobre as possíveis retaliações que os estudantes 
poderão sofrer caso mantenham a mesma postura crítica e questionadora perante o processo educativo da nova escola. Enfim, as crianças são treinadas para que entendam que aquilo que é inconcebível no Âncora em outras escolas é perfeitamente aceitável e estimulado. Sei que pode parecer estranho mas, enquanto os anos finais da educação básica não forem instaurados na instituição, essa continuará sendo a solução encontrada pelos educadores. Talvez não seja a melhor escolha, mas "seria leviandade deixar que os estudantes migrem para outras escolas e encontrem surpresas das quais não foram alertados", informou um educador. A esse respeito, presenciei uma indagação de um estudante às vésperas de sua saída do Âncora: "mas se eu já li no livro e guardei na minha cabeça, ainda preciso escrever na prova. Pra quê?”.

A forma como as escolas convencionais operam é um ponto em que, a meu ver, a educação escolar conservadora conseguiu seu maior "sucesso": categorizar pessoas de acordo com um modelo ideal. É um sistema que ensina os estudantes a aspirarem a esse formato e a se parecerem cada vez mais uns com os outros. Para isso, Hecht (2016) deu o nome de "modelo quadradista". Segundo ele, o sistema de ensino atual converte todas as crianças em "quadradistas", ou seja, promove a ideia de que o grau de sucesso está ligado a um conjunto de conquistas como tirar boas notas ou memorizar as lições. Assim, mesmo quando as ocupações dentro desse quadrado terminam, as pessoas continuam preservando seus princípios de categorização automaticamente e, por consequência, seguem acreditando que aqueles que venceram dentro do quadrado (que obtiveram excelentes avaliações, terminaram sua graduação, terminaram seu doutorado etc.) são indivíduos de maior sucesso, mais importantes e melhores. Dentro dessa jornada do quadrado, os saberes são adquiridos de forma hierárquica, o que equivale a dizer que tudo que é aprendido serve como base para um conhecimento por vir. Tal jornada segue da ignorância para a iluminação, visando satisfazer o que é imposto por autoridades externas. Desse modo, as crianças aprendem que: 1) existe um conhecimento correto e que está nas mãos das autoridades; 2) a sua busca pessoal não tem significância porque não é relevante para o aprendizado; 3) o seu posicionamento pessoal não é relevante, porque o conhecimento correto foi encontrado por indivíduos iluminados e repousa na mão das pessoas certas; 4) qualquer investigação ou descoberta que não esteja alinhada com o conhecimento considerado correto está errada; 5) se espera que não se cometam erros, porque isso leva o estudante a perder pontos em sua avaliação final; 6) é de extrema importância provar que você sempre tem a resposta certa. 
O tipo de trabalho adotado pelo Âncora permite que todos os estudantes aprendam os conteúdos apresentados por qualquer escola mas, mesmo assim, se distancia desse modelo apresentado acima. Na Escola, as crianças assumem compromissos e não se contentam apenas com a aquisição do conhecimento a partir dos roteiros de aprendizagem. Passam também para a ação, que inclui a intervenção em problemas comunitários. Alguns projetos partem de necessidades manifestadas pelas crianças. Podem ser de natureza particular, curiosidade própria, dando origem a aprendizagens no contexto de um projeto de vida. Outros têm sua origem nas necessidades sentidas pela comunidade. Dessa forma, os conhecimentos aprendidos na Escola são usados para transformar a realidade dos estudantes. Quando a criança apresenta um desejo, uma necessidade ou um sonho, o educador-tutor adota isso como um ponto inicial e, assim, começa a investigação. São colocadas perguntas como: por que você deseja fazer isso? De que modo será feito? Qual será o ponto de partida? O que se sabe sobre isso? Qual a duração estipulada? O que é necessário aprender para executar isso? A partir desses questionamentos é que se dá o trânsito entre as diversas áreas do conhecimento. Assim, cada projeto de aprendizagem começa a ganhar um sentido, o que faz com que não sejam apresentados conhecimentos isolados da realidade que podem ser esquecidos facilmente pela ausência de sentido.

Dentre os projetos de aprendizagem que foram e estão sendo realizados pelos estudantes do Âncora, destaco dois: o "Acabar com o lixo do mundo" e a "Viagem de Sofia". O primeiro é um projeto coletivo composto por mais de 20 crianças que se encontram todas as quartas-feiras pela manhã para pensarem soluções para o problema dos resíduos sólidos descartados de maneira incorreta. Esse projeto começou em 2014 com a pretensão de uma criança, como informa o título, de acabar com o lixo no mundo. Mas, como ela havia se incomodado primeiramente com o lixo do seu bairro (Jardim Recanto Suave), resolveu diminuir as expectativas e começar por ali mesmo. Assim, mapeou o lixo da sua comunidade, convidou seus colegas e envolveu o poder público local para a realização de um mutirão de limpeza. Após essa iniciativa, as crianças perceberam que, apesar de notarem mudanças significativas nas atitudes dos moradores, o projeto não foi suficiente para resolver o problema do lixo. Por isso, continuam, até hoje, promovendo diversas ações pelo bairro como campanhas de conscientização, debates, instalação de lixeiras seletivas e promoção de cursos sobre reciclagem. O segundo projeto foi uma iniciativa individual de uma estudante chamada Sofia. Ela produziu um cimento espacial a partir do bagaço de cana-de-açúcar e foi convidada para viajar aos Estados Unidos e visitar a NASA (National Aeronautics and Space Administration). 
A NASA tem um programa para incentivar a ciência entre os jovens brasileiros. O projeto da Sofia foi selecionado em 2018 entre milhares de outros projetos de estudantes brasileiros, o que demonstra que, quando uma criança escolhe aquilo que deseja aprender, os resultados podem ser positivos.

Outros projetos menos "badalados”, mas não menos importantes, também estão sendo realizados pelas crianças da Escola. Alguns exemplos: "Projeto Parque Aquático", "Praia", “Andar de Avião", “Guerra de Bexiga com Água”, “Conhecendo Meus Vizinhos”, “Ajudando Nossa Rua”, "Animais Abandonados". Todos esses projetos, apesar de serem gerados a partir de necessidades individuais, sempre acabam envolvendo o coletivo de alguma forma. Podem nascer a partir de uma brincadeira, como o "Projeto Cisterna", e se transformar em uma séria reflexão e ação sobre a crise hídrica. O estudante que criou esse projeto construiu e distribuiu várias cisternas pequenas pelas casas do seu bairro. Podem nascer também da carência de recursos e instrumentos, como no caso de uma estudante que queria desenvolver uma pesquisa sobre química e conseguiu angariar fundos para a construção de um laboratório na Escola. Ou, então, podem nascer pela simples curiosidade, como no "Projeto Origem", onde o estudante desejava apenas conhecer melhor a hereditariedade das famílias vizinhas. A realização desses projetos não se restringe à esfera escolar. As crianças marcam reuniões, buscam parceiros e promovem diversas atividades com pessoas de fora da Escola. E, por mais que fossem atividades "escolares", notei que as crianças as encaravam com bastante naturalidade, como fruto da vontade. Muitos projetos continuam com o fim do período escolar. Alguns exestudantes do Âncora continuam desenvolvendo seus projetos mesmo com o término da educação básica. Isso mostra que realmente os estudantes encaram os projetos de aprendizagem como projetos de vida e não como uma tarefa escolar enfadonha e sem propósito.

No Âncora, existe uma verdadeira busca por um significado da aprendizagem. As crianças são estimuladas a todo momento para que ampliem as suas visões para os problemas vividos em sociedade. Quando uma criança aprende que um determinado problema enfrentado por outra pessoa é também de responsabilidade dela, sua consciência é alargada de modo que não haja mais espaço para uma compreensão mesquinha e individualista do grupo social a que pertence. Nessa perspectiva, a grande diferença dos projetos desenvolvidos no Âncora para as demais escolas é que, naquela, todos os projetos partem das necessidades de um indivíduo ou de um coletivo. Na Escola, há uma vontade comum entre os educadores para que as crianças sejam protagonistas do próprio aprendizado. Percebi que o objetivo a ser alcançado por eles é 
uma combinação, a mais elaborada possível, entre projetos profissionais e motivações pessoais. Isso faz com que a instituição não tenha somente a função de instruir, mas que também alcance uma função educativa que, ao mesmo tempo, seja encorajadora da diversidade cultural entre os estudantes e favoreça as atividades por meio das quais se afirmam as suas personalidades individuais. A própria diversidade humana exige que os modelos de aprendizagem reconheçam a diferença e a unicidade dos estudantes.

Mas o que acontece em outras escolas? Um local que era para ser um espaço motivador, que instigasse as diferentes descobertas das crianças, acaba se transformando em um ambiente de crianças entediadas que não desistem de buscar alternativas para fugir das experiências que aparecem em seu percurso escolar. Certa vez me deparei com um estudante, na sala da direção de uma escola privada que recebe filhos da elite paulistana, que tinha sido advertido por ter sido a terceira vez que estava dormindo em sala de aula. Outra vez, nessa mesma escola, conheci um rapaz, estudante do Ensino Médio, que já tinha sido expulso de três instituições devido à prática frequente de cabular aulas, ou, em suas palavras, "faltar sem uma mentira adequada". Exemplos como esses não faltam. Creio que isso aconteça porque a maioria das pessoas possui diferentes objetivos de vida e opta por caminhos diferentes para atingi-los. Há quem goste de cuidar de animais, enquanto outros não suportam tal prática; há quem goste de estudar geografia, ao passo que outros se sentem entediados com a disciplina; há quem goste de assistir palestras, algo que, para outros, funciona como um sonífero. O que quero afirmar é: cada ser humano tem um perfil único de aprendizagem, que não é levado em conta por essas escolas. Nesse sentido, Touraine (1999) traz a seguinte reflexão:

A escola deve reconhecer a existência de demandas individuais e coletivas, em vez de acreditar que antes da sua socialização pela escola o indivíduo é um selvagem. A criança que ingressa na escola não é uma tábula rasa sobre a qual o educador vai inscrever conhecimentos, sentimentos e valores. A criança tem, em cada momento da vida, uma história pessoal e coletiva, que sempre vai apresentar traços particulares. [...] Alguns ainda hoje se veem tentados a considerar a educação apenas como uma preparação para a vida assim chamada ativa, e portanto a pilotá-la a favor da corrente, isto é, a partir das demandas e das capacidades do mercado de trabalho. Mas será que se pode ainda falar, neste caso, de idéias sobre a educação? Certamente não, pois deste modo não se levam absolutamente em conta as demandas dos educandos que se preocupam com a sua personalidade, com sua vida e seus projetos pessoais, com suas relações com os pais e os colegas. Não se pode também falar de educação quando se reduz o indivíduo às funções sociais que ele deve assumir. Além disso, o futuro profissional é pouco previsível, e irá comportar para a maioria daqueles que hoje freqüentam a escola descontinuidades tão grandes que é preciso antes de mais nada pedir à escola que prepare os estudantes para aprender a mudar em vez de lhes permitir adquirir competências específicas, que correm o risco de ficar logo ultrapassadas ou inúteis para eles. (p. 322) 
Essa disposição para que a aprendizagem se realize a partir de projetos de pesquisa, no Âncora, está atrelada à noção de que educadores são pesquisadores e à ideia de que a escola deve contribuir para a realização das aspirações comunitárias. Desse modo, o estudante é visto da mesma forma, dentro ou fora da escola, pois carrega consigo os diferentes elementos presentes nesses ambientes. Com isso, a divisão entre escola e comunidade tende a se diluir, porque todo o contexto está atravessado pela prática educacional. Assim, descartar o lixo em locais inapropriados, solucionar uma discussão através do confronto físico ou permanecer em casa viciado nas redes sociais da internet também são questões assumidas pela Escola. Conforme contou um educador, ao lado do Projeto Âncora existe uma comunidade que é banhada por um córrego. Segundo ele, essa área é constantemente inundada e quase sempre as famílias perdem suas posses materiais. E, mesmo perante essa situação, “as crianças que moram nessa comunidade frequentam outras escolas que as obrigam decorar os afluentes do Rio Amarelo [China], mas não as fazem aprender, refletir e descobrir sobre o córrego vizinho e os efeitos que isso tem sobre suas moradias ou sobre suas próprias vidas".

Na Escola Projeto Âncora, o fato de não ter aula abre um enorme leque de possibilidades para a atuação do educador. Esse permanece em tempo integral com todos os estudantes e com os outros educadores. Não está restrito a uma turma em uma sala fechada. Não é dependente de um material didático obrigatório, pois tudo pode ser utilizado como recurso para a aprendizagem. É livre, assim como os estudantes, para circular pelos diferentes espaços escolares. Não precisa ficar falando para todas as crianças ao mesmo tempo, porque consegue se dirigir a cada uma delas ou a pequenos grupos. Isso dá origem a um tipo de envolvimento pessoal muito mais intenso. São criados laços afetivos mais fortes entre educadores e estudantes, que ultrapassam aqueles do docente que é obrigado a dar aulas expositivas para um determinado número de crianças confinadas em um local específico. Não acredito que o educador seja capaz de criar bons vínculos afetivos com os estudantes durante uma aula. Isso é possível apenas em uma relação mais personalizada. Assim, se uma criança não está conseguindo aprender determinada coisa no Âncora, os educadores buscam outras alternativas. Não existe uma regra: a preocupação principal é fornecer as condições necessárias para que a criança aprenda.

Por vezes, ocorre de algumas crianças escolherem um mesmo tema de estudo e pesquisa. Quando isso acontece, um educador especialista no assunto oferece a possibilidade de os estudantes terem uma aula expositiva. Para isso, agenda-se um horário e os interessados 
se matriculam. Por mais que seja algo extremamente raro, pode acontecer. É uma prática facultativa, o estudante se inscreve porque deseja e, se sua dificuldade for apenas em um ponto bastante específico do tema e o educador já tiver sanado sua dúvida e seguir explicando outras partes para os demais, o estudante pode simplesmente se levantar e sair do local. Procedimento esse muito diferente em relação às aulas expositivas presentes em outros contextos. Quero deixar claro que não há uma condenação do fenômeno "aula", por parte dos educadores da Escola: ela é apenas usada de uma forma mais objetiva e mais espontânea. Por isso, se for necessário, em alguns momentos, dar uma aula expositiva ou usar um livro didático, os educadores da Escola o farão sem nenhuma dor na consciência. Nas outras escolas, a criança tem aula e eventualmente fará algo ligado a seu interesse. No Âncora, eventualmente, e se for necessário, a criança tem aula e sempre fará algo ligado ao seu interesse. Aquilo que é a exceção no Âncora é a regra na maioria das escolas. No Âncora, a criança frequenta a escola para aprender e não para assistir aula. Essa é uma abordagem diferente comparada a outras escolas, onde as crianças vão para cumprir uma carga horária e manter uma frequência mesmo que não estejam aprendendo.

Ainda no que diz respeito ao fenômeno aula, recordo de uma situação vivida durante uma visita a uma escola pública, localizada na cidade de Diadema (SP). Escutei um desabafo de um professor de matemática que aparentava ter uns 40 anos de idade: "Minha turma de $8^{\circ}$ ano é muito boa. O único problema são as perguntas feitas por uma meia dúzia de alunos e que acabam quebrando o ritmo da aula. E, para piorar, às vezes as perguntas não têm nenhuma relação com a minha aula”. Não consegui entender, até hoje, o que aquele professor estava querendo dizer com a expressão "quebrar o ritmo da aula". Evoco outros episódios semelhantes que presenciei observando aulas nessa mesma escola, mas desta vez relacionados aos estudantes. Teve um aluno que perguntou: "professor, deixo quantas linhas para a resposta? Uma ou duas?". Um segundo rapaz também emendou: "respondo as questões com caneta ou de lápis?”. Outro dia, durante uma aula de geografia, uma menina perguntou para a professora: “qual é a página do livro que posso consultar para responder as atividades?”. A professora respondeu: "se você tivesse prestado atenção na minha explicação, responderia sozinha, sem o livro". A jovem estudante argumentou: "eu prestei atenção, só quero saber a página para responder certo, do jeito que está no livro, senão depois você não me dá o visto”. Sem paciência, a professora disse: "é só olhar no sumário e procurar pelo assunto da aula". Por fim, a menina faz uma nova pergunta: “professora, o que é um sumário?”. Fico pensando ao observar esses diálogos, e me pergunto qual será o motivo de tanta preocupação entre os professores que 
buscam alternativas vãs para melhorar um dispositivo que não pode ser melhorado: a aula. Penso também sobre os motivos que levam as escolas a retirarem o poder de decisão dos seus estudantes. Como aceitar uma criança que não consegue decidir entre a caneta azul ou preta? Escolher entre 5 ou 10 linhas para sua própria atividade? Farão o quê quando saírem da escola e precisarem fazer escolhas? Darão telefonemas ao professor?

Para pensar sobre essa questão, Pacheco, no seu Pequeno dicionário de absurdos em educação, relata a seguinte situação:

\begin{abstract}
Alguns amigos dizem-me que as aulas que dão já não são como antigamente e que, agora, as preparam cuidadosamente. Falamos diferentes linguagens. Eles falam-me de aulas "interessantes". E eu não consigo entender como pode ser interessante escutar respostas a perguntas que ninguém fez. Eu sei que há professores que preparam bem as suas aulas, que definem criteriosamente os objectivos, elaboram rigorosamente um plano e elaboram materiais auxiliares de ensino. Não duvido de que sejam profundos conhecedores do assunto que vão lecionar. Mas terão pensado bem para quem vão "dar a aula"? Se todos os alunos estão aptos a recebê-la? Se todos irão aprender no mesmo tempo, do mesmo modo, no mesmo ritmo? Dizem-me que as aulas de hoje são diferentes e melhores que as dadas antigamente. Mas "aula" não é coisa digna de ser melhorada, é coisa para ser questionada. Sem negar a pertinência de aulas, no modo de fazer escola que ainda temos, pergunto aos professores se haverá um só modo de fazer escola e se esse modo tem por recurso exclusivo a "aula". E, aqui, é que a coisa se complica. (2009, p. 18)
\end{abstract}

O apego a esse modelo padrão de aprendizagem faz com que muitos estudantes que chegam ao Âncora se sintam inseguros em relação ao próprio aprendizado. Não se pode esperar que as pessoas aceitem o diferente sem conhecer. Por esse motivo, a Escola realiza todo um trabalho de acompanhamento com as famílias e com os novos educandos. Qualquer responsável tem passe livre para frequentar o projeto. Segundo relato de um dos educadores, "no início foi mais difícil explicar do por que não ter provas, por que não ter lição de casa, mas hoje as crianças estão mais confortáveis e as famílias ajudam até mesmo na divulgação do projeto". Esse momento do encontro entre estudante, educador e família resulta em um conforto para os pais do estudante, que percebem que seu filho está aprendendo mesmo diante de uma perspectiva diferente. Todo o processo de aprendizagem que a criança vive na Escola é comunicado à família por meio de relatórios individuais, pelo registro do percurso da aprendizagem em plataformas virtuais e, principalmente, por meio da própria criança que informa aos pais sobre o seu desenvolvimento. Quanto a essa insegurança natural dos primeiros dias na Escola, trago um depoimento de uma jovem de 12 anos, que chegou no Âncora após estudar em outras duas escolas da região: 
Quando eu entrei aqui eu achava que a minha escola antiga era a correta. Achava que eu jamais poderia aprender sem ter aulas e outras obrigações das escolas convencionais. Por isso, eu não gostava muito daqui no início. Mas depois de um tempo tudo começou a fazer sentido para mim. Lembro quando escrevi um texto e a professora me disse que não tinha sequer um erro ortográfico. Foi uma satisfação imensa, porque eu amo escrever e vi que estava me desenvolvendo sem nenhuma pressão. (informação pessoal)

Observei que, conforme aumenta o tempo de adaptação das novas crianças, que estudaram em outras escolas, aumenta a vontade de frequentar os espaços do Âncora. "Eu gosto muito de estudar aqui porque você não precisa ficar na sala com uma cadeira virada para a lousa ouvindo a professora. Aqui eu posso escolher meu projeto e fazer o que eu gosto em espaços livres", narrou um estudante. Esse mesmo estudante entusiasmado disse que, no início de sua transição para o Âncora, já chegou em casa chorando e dizendo para sua mãe que não aprenderia nada na Escola. Hoje em dia, conforme informou sua mãe, "ele não quer mais saber de ficar em casa. Só pensa na escola”. Ela também parece estar satisfeita com o Âncora: "o que eu mais gosto nesta escola é o trabalho de incentivar na criança aquilo que ela tem de melhor. E eles esperam e respeitam o tempo de cada criança”. A mesma mãe disse também que gosta de acompanhar de perto os resultados do filho e percebeu que sua leitura e comunicação, em suas palavras, "tiveram um salto". Outra estudante satisfeita com a migração para o Âncora também relatou: "aqui é um lugar de sonhar. A gente estuda a partir dos nossos sonhos e vontades que se tornam projetos. Aprendemos brincando também, não só escrevendo. Isso não tem preço".

Claro que também existem os insatisfeitos, os que não se adaptam. Quando lá estive, encontrei apenas dois. O primeiro já estudava havia três anos no Âncora e disse que ainda sentia falta da sua antiga escola: "aqui o ensino é muito fraco, tenho saudade de estudar em uma escola normal". O segundo, havia mais tempo no Âncora, quase cinco anos, disse que não entendia por que tanta gente quer entrar no Âncora: "tem um monte de gente querendo entrar, mas eu quero sair daqui. Preciso de gente pegando no meu pé, aqui sou muito livre”. Segundo os funcionários da Escola, esses casos não são frequentes, mas existem. A coordenadora pedagógica informou que "A escola faz de tudo para entender as crianças e oferecer as condições necessárias de desenvolvimento, mas nem sempre é suficiente. Não forçamos ninguém a fazer nada, pois a coerção não encoraja a criatividade".

Os próprios educadores também se questionam constantemente acerca dos procedimentos de aprendizagem presentes no Âncora. Afirmam que a natureza da aprendizagem baseada em projetos requer compromisso, criatividade, esforço, atenção e 
avaliação. Assim, promovem discussões semanais para partilharem os princípios que julgam ser necessários para viver em sociedade. Não perdem tempo falando sobre novos métodos de ensino, porque consideram que o ensino, em si mesmo, não tem grande importância. Também concordo que é coisa de segundo plano se uma escola possui ou não algum método especial para ensinar a calcular, pois calcular é importante para os que desejam aprender essa habilidade. E os que assim desejarem aprenderão, seja qual for o modelo de ensino que recebam. Essa postura não é um desprezo a uma filosofia pedagógica; pelo contrário, a Escola não se vincula a uma metodologia de ensino, mas se inspira em um amplo referencial teórico. Tal referencial aponta, sobretudo, para educadores brasileiros como Rui Barbosa, Rubem Alves, Paulo Freire, Nilde Mascellani, Maria Amélia Pereira, Lourenço Filho, Lauro de Oliveira Lima, Helena Antipoff, Florestan Fernandes, Darcy Ribeiro, Anísio Teixeira, Agostinho da Silva e muitos outros, além da própria Constituição Federal, do Estatuto da Criança e do Adolescente (ECA), da Lei de Diretrizes e Bases da Educação Nacional (LDB), da Lei Orgânica da Assistência Social (LOAS) e da Base Nacional Comum Curricular (BNCC). Essa adoção multirreferencial é apoiada pela crença de que as diferentes áreas do conhecimento humano são indissociáveis: todos estão relacionados e, por isso, não existe um conhecimento mais importante do outro. Sendo assim, não faz sentido optar por uma única linha de pensamento.

Os educadores citaram alguns pontos que são desafiadores e que precisam ser melhorados dentro da Escola. Um dos desafios é trabalhar com o estudante sem dar respostas prontas, instigando-o a pensar. Como a maioria dos educadores carrega "vícios" das suas práticas educacionais anteriores à adequação, não é algo fácil. Uma das educadoras que trabalhou durante alguns anos na rede privada confessou que por muito tempo teve que se espelhar em um determinado padrão docente, mas agora que está no Âncora se sente mais livre. "Mesmo sendo a professora que sempre sonhei, ainda tenho dificuldades para romper com certos costumes passados", informou. Outro desafio é a necessidade de otimizar o tempo. Os educadores lutam para encontrar uma dinâmica adequada de organização de suas atividades de modo que não seja necessário dispor de tanto tempo fora da carga horária semanal para atenderem a planejamentos, reuniões e outras demandas. "A nossa qualidade de trabalho será muito mais eficaz se não estivermos tão cansados. Entender e oferecer as condições necessárias para as crianças exige tempo", narrou um dos educadores. De fato, a rotina de trabalho dos educadores do Âncora, apesar de prazerosa, é extenuante. Estão sempre muito atentos. A todo momento tentam criar situações de aprendizagem. Como no dia em que um educador veio para a Escola vestido com uma camisola feminina para chamar a atenção dos estudantes e suscitar 
um debate sobre aparência. Ou então, o fato de alguns educadores andarem com um livro que estejam lendo, por toda a escola, para que as crianças se interessem pela leitura.

Do outro lado, a maioria das escolas continua sendo guiada por práticas educacionais costumeiras. Segue fragmentando o conhecimento em disciplinas e especialidades que são centradas no professor e no modelo de transmissão de saberes, considerados legítimos e indispensáveis. O que explica um tempo de 50 minutos para estudar biologia e outro tempo de 50 minutos para estudar português? Cinquenta, 60, 85 minutos, para qual estudante? A criança continua sendo vista como um ser vazio, uma tábula rasa, servil e obediente, destituída da sua capacidade criativa. Acredito que para mudar essa visão a escola precisa um espaço de produção de conhecimento. Mas como é possível essa alteração de papel dentro de uma estrutura de aulas, disciplinas, séries e testes? A prática da pesquisa pressupõe liberdade, tempos maleáveis, erros e socialização dos resultados.

No entanto, parece que o sistema educacional adotou uma hierarquia de disciplinas. No topo da pirâmide estão matemática e línguas, em seguida vêm as ciências humanas e, na base, estão as artes. Parece que não há nenhuma escola que ofereça a oportunidade de as crianças dançarem na mesma proporção da oferta do ensino da matemática, por exemplo. Por que não? Dançar é tão importante quanto aprender matemática. Assim, essa hierarquia está apoiada em duas premissas: primeiro, a de que os assuntos mais relevantes ao mundo do trabalho são prioridade. A segunda, que realmente dominou nossa visão de inteligência, é a projeção criada pela universidade em modelar a educação básica à própria imagem. A educação básica é vista como um período prolongado para atingir a admissão em universidades. A consequência é que muitas pessoas altamente talentosas, mas que estão fora dessas exigências, não conseguem se enxergar dessa forma, porque suas aptidões foram estigmatizadas ou desvalorizadas pela escola. 


\subsection{Formas de avaliação}

O processo de avaliação na Escola Projeto Âncora é algo natural, faz parte do cotidiano escolar e ocorre a todo instante. Não existe um momento específico para que o estudante seja avaliado. Quando a criança sente que já sabe, ela realiza uma autoavaliação ou procura um professor para ser avaliada. Isso faz com que a avaliação perca aquela função costumeira, como um momento marcante, traumatizante e angustiante. "A avaliação no Âncora não se dá em um momento exclusivo. Avaliar é algo que acontece a todo momento por todas as pessoas", defendeu o educador. A Escola também não compactua com a ideia de uma avaliação estanque, de caráter classificatório, quantitativo e comparativo. Trabalham com uma avaliação formativa, contínua, sistemática e extremamente rigorosa quanto aos registros de desempenho dos estudantes. É priorizada nesse processo avaliativo a própria aprendizagem de cada educando, o seu desenvolvimento cognitivo e comportamental.

Por mais que a avaliação não esteja centrada exclusivamente na aprendizagem, ainda existe uma preocupação, entre os educadores, sobre se o aluno aprendeu ou não aprendeu determinado assunto. Para isso, verifica-se o desenvolvimento da aprendizagem de cada estudante de acordo com a relação de objetivos presentes na Base Nacional Comum Curricular (BNCC) e nos respectivos currículos subjetivos. Fazem isso da seguinte maneira: primeiro, os professores avaliam o desenvolvimento dos projetos de aprendizagem, organizam e registram em uma lista de verificação todas as habilidades e competências que as crianças precisaram alcançar para cumprir com as suas atividades. Logo após, vinculam os saberes aprendidos aos objetivos previstos na BNCC. Por fim, essa lista de verificação de conhecimentos opera, ainda, como um documento que apresenta de forma detalhada a evolução dos estudantes, de forma que a trajetória de cada um possa ser acompanhada pelos mesmos, pelos educadores e pelos pais. Esse documento substitui o conhecido "boletim escolar". Ao contrário da exibição por meio de escalas numéricas, esse boletim é composto por relatórios, imagens e vídeos, entre outras coisas.

Cada educador-tutor reúne seu grupo de estudantes tutorandos ao final do dia. Essa roda é chamada de "Encontro do dia". Durante esse momento, entre outras atribuições, avaliase coletivamente o dia de cada um. A avaliação não diz respeito apenas aos projetos de aprendizagem: os diferentes acontecimentos e sentimentos também são levados em conta. $\mathrm{O}$ educador sempre procura adotar uma postura de facilitador, tenta instigar as crianças a partir de 
provocações para que elas expressem sem medo as ocorrências do dia. No que diz respeito à aprendizagem, o educador apenas responde as possíveis dúvidas dos estudantes e sugere algumas alterações quando se faz necessário. $\mathrm{O}$ encontro do dia também serve para entregar comunicados para os pais, para a apresentação de projetos e para levantar alguns possíveis conflitos pessoais. Tal instante é, acima de tudo, um local reservado para reflexão e diálogo. Esse método de avaliar os educandos é visto como um processo mediador das aprendizagens, que procura conduzir de modo construtivo o percurso escolar de cada um. Isso permite evidenciar o progresso do estudante em diversas dimensões. Os educadores se aproveitam de todos os momentos da criança para verificar o que ela aprendeu e o que ainda precisa ser aprendido. No Âncora, o ato de avaliar não cessa: até mesmo nos momentos em que uma criança está ajudando outra, ela está, ao mesmo tempo, aprendendo e sendo avaliada.

A avaliação no Âncora não tem nada a ver com uma escala de notas e, muito menos, com provas. Ela serve apenas para ajudar o estudante a alcançar um patamar desejado por ele mesmo. Serve para que o estudante reflita sobre o que fez, o que aprendeu, o que não fez, o que não aprendeu e por que não fez ou não aprendeu. Esse processo de avaliação é algo simples. A criança diz que já sabe determinado tema e o professor aparece para verificar, tirar dúvidas e sugerir o que for necessário. Esse momento avaliativo é acordado entre estudante e educador e é feito assunto por assunto. Não existe a prática comum de esperar acumular centenas de temas para depois ser cobrado em um exame. Não há também a atribuição de números ou letras para dizer que uma criança obteve uma nota x. Apenas por uma exigência burocrática, a Escola atribui a pontuação máxima para ser enviada à secretaria regional de ensino. Nesse aspecto, a Escola não discute e simplesmente cumpre a determinação. Essa postura da Escola ainda provoca um certo espanto entre a comunidade, como pode ser visto no depoimento abaixo de uma mãe que faz parte do projeto:

\footnotetext{
No início as pessoas me criticavam dizendo que eu era louca de deixar meu filho no Âncora porque era uma escola diferente e não tinha provas. Ainda bem que eu não escutei o que as pessoas disseram, porque após três anos na escola percebo que meu filho está muito focado e é muito bom em matemática. Fico tão feliz e ainda aprendo com ele. Ele aprendeu a respeitar mais as pessoas, valorizar os amigos e as pequenas coisas. (informação pessoal)
}

Claro que a Escola Projeto Âncora não é uma "ilha paradisíaca" da educação. Sendo assim, seus problemas são consequências das suas escolhas educativas. Se uma escola escolhe avaliar por meio de exames, estará escolhendo os problemas envolvidos com esse tipo de atitude, como a cola, por exemplo. Se outra escola escolhe não ter exames, não faz o menor 
sentido se preocupar com a cola. Como colar em uma autoavaliação? Por que o estudante sabotaria o resultado de uma avaliação que pode prejudicar o seu próprio desenvolvimento? É uma demonstração de que as práticas educativas carregam problemas inerentes. No caso do Âncora, não há preocupação alguma com resultados que são irrelevantes para o estudante, tais como "isso que eu estudei vai cair na prova?" ou "por que a gente precisa anotar isso?". Em vez disso apresenta-se um tipo diferente de discurso, de caráter crítico, oriundo do interesse e da curiosidade. Uma das expressões objetivas desse posicionamento pedagógico é que, quando uma criança se transfere para outra escola, ela não leva apenas um histórico escolar, mas sim um dossiê completo com todas as informações da sua trajetória escolar. Esse dossiê é extenso, pois a Escola defende a ideia de que tudo é aprendizagem e, por isso, tudo é avaliação também, são sinônimos. Sendo assim, o registro da avaliação não se baseia em uma nota vazia.

Ao contrário do que se imagina, os estudantes se saem muito bem quando precisam enfrentar algum tipo de exame oficial. Aqueles que desejam entrar para uma universidade fazem exercícios práticos para os testes, porém são apenas parte da preparação e não provas obrigatórias. Vários estudantes que saíram do Âncora e foram submetidos a provas externas apresentaram bons resultados. Segundo a fundadora da Escola, os estudantes continuam sendo acompanhados mesmo quando saem da instituição e todos aqueles que desejaram realizar testes tiveram excelentes devolutivas. A fundadora ressalta que a Escola se concentra mais nos resultados relacionados à questão atitudinal dos estudantes do que nos resultados da questão cognitiva. Segundo ela, "a questão cognitiva é hipervalorizada na nossa sociedade, que deveria se atentar para o fato da nossa classe política ter tirado ótimas notas e ter estudado nas melhores escolas”. Dessa forma, “é preciso avançar para além da dimensão cognitiva, que é apenas uma das múltiplas dimensões do ser humano", finalizou a fundadora. E isso é possível de ser realizado no Âncora porque a avaliação está ligada a um processo de amadurecimento do estudante que envolve responsabilidade, autonomia, atitude e respeito.

Entende-se comumente que, dentro espaço escolar, a função de avaliar é restrita ao educador. No entanto, no Âncora a avaliação não está centrada apenas no desempenho dos estudantes. Todas as pessoas são avaliadas e todas as pessoas avaliam. Não há alguém posicionado acima do corpo discente ou do corpo docente e responsável exclusivamente por entregar pareceres. O que quero dizer é que não existe uma terceirização da avaliação. Cada educador e cada educando realiza uma autoavaliação e estabelece o próprio juízo de valor. Existe uma valoração que é comum entre os pares, mas ninguém precisa provar seu valor, ou 
seja, ninguém precisa receber autorização de um especialista dizendo que aquilo que está fazendo é certo ou errado. Também não é aceitável envolver no processo avaliativo pessoas que não fazem parte da Escola, que nela não executam nenhum tipo de atividade ou que não estão matriculadas.

O fato de que o Âncora é uma ONG lhe concede essa opção de não participar de avaliações externas. Entretanto, enquanto existirem exames oficiais, eles terão força sobre qualquer escola. Por esse motivo, para que as crianças possam vivenciar os desafios que encontrarão além dos muros escolares, o Âncora formou uma equipe de educadores que são responsáveis por estudar todas as perspectivas metodológicas, as formas de aplicação e promoção de simulados. Consideram fundamental que a aplicação dos simulados seja realizada nas mesmas datas que correspondem às avaliações externas, e que as regras e as condições específicas de cada exame sejam respeitadas. Os estudantes realizam as provas com muita tranquilidade, alegria e curiosidade. Geralmente, após o término das provas as crianças procuram seus educadores para as ajudarem a colocar em seu roteiro de aprendizagem as possíveis dificuldades enfrentadas durante o teste.

Escutei de muitos docentes, colegas de profissão, que as crianças em escolas que não possuem provas "vivem na moleza". O argumento defendido por eles é que, como nessas escolas não há testes obrigatórios e a avaliação é vista como uma prática tão natural e frequente quanto o ato de observar, as vidas dos estudantes são muito mais fáceis do que as das suas contrapartes que vivem nas escolas convencionais que optam pelas provas. Penso que o oposto é mais adequado à realidade: procurar uma área de interesse e submeter-se a uma autoavaliação constante exige muita força interior. Por outro lado, a escola que pretende ser apenas uma ferramenta objetiva de medição de notas cria o que conhecemos como curva normal, na qual crianças são medidas e alocadas sob três categorias: excelentes, medianas e fracas. Presumo que a maioria das pessoas é categorizada como mediana, alguns como excelentes e outros, como eu, como fracos. Tudo isso é estipulado em relação a um objeto ideal de aprendizagem, onde aquilo que um estudante realiza e que faz com que ele seja único não é relevante para a vida escolar. O que importa dentro dessa lógica é o quanto cada um consegue se aproximar de um modelo ideal, ou seja, o mais próximo das notas altas. Em vista disso, quando alguém apresenta respostas que não estão de acordo com esse modelo ideal, o resultado é sempre uma desqualificação desse indivíduo. 
Acredito que, mal ou bem, esse tipo de prática educacional leva o estudante a aprender matemática e consegue medir se ele reproduziu ou não de maneira correta aquilo que foi ensinado. No entanto, isso gera uma atitude negativa em relação ao conhecimento aprendido e tal sentimento não é considerado pelos exames oficiais. E é justamente nesse aspecto emocional que a abordagem do Âncora se destaca. O modo convencional de avaliar ainda se concentra na assimilação de um aprendizado que tem por objetivo julgar e estabelecer divisões entre a resposta certa e a resposta errada, entre as pessoas que sabem e as pessoas que não sabem. Preconiza também o quanto é indesejável e perigoso cometer erros. Isso faz com que os estudantes permaneçam em um "eterno estado de alerta", verificando o tempo todo a qual grupo pertencem: dos que sabem ou dos que não sabem; ou então, para aqueles que são mais arrogantes: quem está no meu nível e quem não está. A consequência desse modo de agir é uma sociedade cada vez mais estratificada.

Há uma concepção, na maioria das escolas, sobre a utilidade de uma prova enquanto ferramenta de avaliação. Prova é aquilo que serve para atestar a veracidade de algo. No entanto, os exames escolares consistem na própria negação dessa definição, pois são insuficientes para tal objetivo. As provas traduzem apenas habilidades periféricas dos estudantes, são incapazes de aferir o real desempenho. Um exemplo disso são os inúmeros casos de pessoas que conseguem diplomas sem nada terem aprendido. Outro exemplo são os estudantes que plagiam trabalhos, que exploram outros estudantes em trabalhos de grupo, que copiam atividades de sites especializados. Fico pensando se isso não é apenas uma forma que os estudantes encontraram para sobreviver a esse sistema. Quase todos os estudantes submetidos a isso admitem que copiam. Esse intuito de conquistar um título, seja na escola seja na universidade, denuncia que a assiduidade escolar está mais voltada para o sucesso nominal (obter um certificado) do que para a satisfação pessoal. Dessa forma, acredito que as fraudes que envolvem as provas ou a falta de originalidade em outras atividades estão na mesma proporção da aplicação insensata das mesmas. São frutos de práticas de avaliação obsoletas. A provocação de Pacheco (2009) ilustra bem esse tipo de prática:

Se uns alunos copiam e outros não, se o acesso à informação deve ser democratizado, se queremos ser justos, bastará que se acrescente ao currículo nacional mais uma disciplina. Poderá chamar-se, por exemplo, "Metodologias e técnicas do bem copiar". Depois, far-se-á um concurso interno, em cada escola, de modo a seleccionar o professor para a leccionar - aquele que, no seu tempo de estudante, tenha dominado bem a utilização de cábulas e copianços. Com a carga horária de uma hora semanal, esta disciplina habilitaria todos os alunos ao uso da variedade de recursos disponíveis 
nesse campo do saber. Deste modo, estaria assegurado o cumprimento do princípio que nos diz ser a escola uma estância de igualdade de oportunidades. (p. 29)

Associada ao mecanismo dos exames e à utilização de meios para sabotá-los está a ideia de professor-vigilante. Para cada exame, o professor é encarregado de vigiar uma sala de aula com a função de evitar que os alunos copiem uns dos outros. Assim, o professor-vigilante parte do pressuposto de que todo aluno é, até que prove o contrário, alguém de posse de uma potencial desonestidade. Haverá um preceito mais antipedagógico e mais destruidor de relações do que esse? No entanto, as ações dos professores-vigilantes não produzem o efeito esperado frente à criatividade dos estudantes: um pequeno papel escondido na manga da blusa, lembretes escritos no braço ou na mesa, uma mensagem codificada pelo celular, enfim, diversas formas para auxiliar a memorização. Nesse "jogo de polícia e ladrão", o educador somente consegue desenvolver junto ao educando habilidades que reforçam a ilusão do método de avaliação por meio de provas. Assim, o professor-vigilante acaba estimulando, mesmo que sem querer, a mentira, a falsidade e a deslealdade entre os estudantes.

Uma prova não passa de um instrumento de seleção arbitrária e, consequentemente, de exclusão escolar. Ironicamente, a tradição escolar prega que o bom professor é aquele que sustenta os índices mais elevados de reprovação. Lembro-me de um episódio, narrado por um colega docente, sobre um professor que todo final de ano chegava às salas dos professores comemorando o recorde de reprovações. Segundo esse colega, tal professor acreditava fielmente na ideia de que quanto maior o número de alunos reprovados maior seria o respeito e a imagem em torno da sua própria pessoa. Casos como esses seguem acontecendo pelas escolas que ainda se pautam em exames: diariamente os estudantes são vítimas desse tipo de poder simbólico que se baseia na rigidez e na falta de senso crítico de alguns profissionais. Quando a reprovação anual é parte desse processo, a situação se agrava ainda mais. Conservo, até hoje, a dúvida que também assalta Pacheco: "se o bom professor é o que mais alunos reprova, o melhor médico será o que mais doentes mata?" (2009, p. 24).

Consigo entender que os professores, reféns de uma formação inadequada, reproduzam aquilo que melhor conhecem e dominam. Durante anos, seja na educação básica ou educação superior, esses professores realizaram exaustivamente inúmeros testes. Para muitos não foi dada sequer a oportunidade de conhecer outras formas de avaliação, por isso não podem ser cobrados para que apliquem ou defendam algo que desconhecem. Sendo assim, são frequentes os casos 
de professores que se lamentam perante o excesso de tempo e esforço despendido nas correções de prova, alegando, na maioria das vezes, que as autoridades escolares os exploram como mão de obra barata. Essas autoridades, por sua vez, gastam fortunas na elaboração de testes que, segundo eles, se constituem na cura de todos os males que afetam o sistema educacional. Como esses testes são, normalmente, instrumentos que pouco ou mesmo nada avaliam, sempre surge a seguinte questão no âmbito escolar: "E o que fazer com o grupo dos atrasados?”. O que fazer com aquela criança que ainda não sabe ler, que não sabe subtrair ou multiplicar? As saídas são sempre as mesmas: novas provas, novos testes, novas pontuações, novas aulas. Cria-se sempre um drama em torno de perguntas fúteis que consistem em assegurar a validade e fidedignidade de uma ferramenta de avaliação totalmente ultrapassada.

A persistência desse tipo de pensamento sobre a avaliação faz com que perdure a visão de que o professor é quem deve avaliar o aluno, segundo aquilo que este tenha aprendido a partir dos seus ensinamentos. O mais engraçado é que todo ser humano avalia o tempo todo, mas parece que, ao chegar no contexto escolar, a avaliação se transforma em algo restrito aos docentes. Para esse problema, Ghanem (2006) aponta que a instituição escolar não é pensada como uma organização que interfere em seu contexto, pois suas práticas educacionais são indiferentes ao lugar e às pessoas que ali vivem. $\mathrm{O}$ autor continua sua argumentação expondo que o objeto da avaliação na escola são os alunos e que estes precisam demonstrar uma aprendizagem esperada como efeito do ensino. Ghanem finaliza com uma possível resposta para essa situação, reconhecendo que a maioria das escolas não dispõe de pessoal capacitado para os desafios previstos pela avaliação, seja pela formação inicial, seja pelas condições de trabalho que encarceram o docente à sala de aula e à atividade de ensinar.

Talvez não haja saída para os que reduzem a avaliação aos aspectos cognitivos. Eliminar as provas das escolas ou fazer uma verificação com enfoque no indivíduo, como no caso do Âncora, são atitudes que podem auxiliar a diminuir os bloqueios, as intrigas, a angústia e a ansiedade dos estudantes, mas ainda se trata de uma noção limitada do ato de avaliar. Fazse necessário que haja um esforço em ampliar a escala de avaliação, rompendo com a exclusividade de pensá-la em termos de unidade escolar e avançando também para a comunidade, a cidade, a região, o país. As questões econômicas, políticas e culturais que englobam a vida das pessoas precisam fazer parte das práticas de avaliação. Não pode haver um desprezo para com os problemas comunitários, os níveis de desigualdade social e, muito menos, as decisões e necessidades de todos os agentes educacionais. Esse processo de alteração 
inclui também a redefinição de indicadores e ferramentas avaliativas. Nesse sentido, a autoavaliação aparece como um instrumento importante, capaz de substituir o individualismo e a competição por uma perspectiva que favorece a cooperação e o autoconhecimento.

Em vez de comprovar ou reprovar, o objetivo da avaliação deveria ser o de assegurar que todos aprendam. No entanto, as escolas permanecem ensinando aquilo que sabem medir e medem apenas aspectos cognitivos que são valorizados pela sociedade. Decorre dessa postura uma centralidade do ensino em detrimento da aprendizagem. Dessa maneira, grande parte daquilo que um estudante aprende no decorrer da vida é desvalorizado pela instituição escolar. Além disso, o papel do educador é deslocado da função de mediador para a função de palestrante-avaliador, que despreza as inclinações e curiosidades apresentadas pelos seus educandos. Soma-se a esse fato, em nível macro, a obstinação pelos resultados positivos em rankings nacionais pautados em exames de múltipla escolha, onde as escolas perdem tempo e energia para provar que seus alunos são bons em reproduzir conteúdos que, hoje em dia, são facilmente acessíveis e irrelevantes do ponto de vista da curiosidade pessoal. Se, ao contrário, as escolas começarem a criar e valorizar estratégias próprias de avaliação e que estejam de acordo com o interesse comum das pessoas que dela fazem parte, poderão mostrar ao mundo a qualidade do que estão fazendo sem se preocupar com as avaliações externas. 


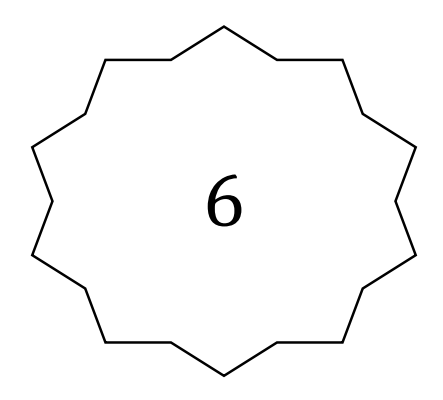

Conclusão 
O Projeto Âncora é uma instituição que existe há quatro anos como escola. E, nesse ínterim, defrontou as dificuldades comuns a qualquer instituição escolar que almeja inovar, ou seja, fazer diferente das demais. A primeira dificuldade foi a substituição de uma cultura assistencial, que durou 17 anos, por uma cultura de integração comunitária. Esta última dependeu da mudança de uma série de fatores para que houvesse uma melhor compreensão dos agentes educativos em torno das ações que alteraram as práticas educacionais costumeiras, e para que construíssem outras formas de aprendizagem. A segunda dificuldade foi a da reelaboração da cultura profissional dos educadores, processo, por vezes, um tanto doloroso e que nem todos conseguiram ultrapassar. No entanto, os educadores que permaneceram na Escola desenvolveram dispositivos essenciais que asseguram práticas educativas baseadas em valores cooperativos. Houve uma adaptação da organização escolar às diferenças individuais. No que diz respeito à sustentabilidade financeira do projeto, essa ainda não está assegurada. Outro ponto é a relação com o poder público, que também não tem sido algo fácil; porém os profissionais do Âncora continuam insistindo na articulação de um diálogo construtivo com as autoridades.

Nas outras escolas o tempo costuma ser algo fixo e a aprendizagem, algo variável. Por exemplo: os estudantes têm um prazo de uma semana para aprenderem sobre geomorfologia. Com o término desse prazo altera-se o assunto, tendo a criança aprendido ou não. Ou seja, o tempo foi fixado em um prazo de sete dias e a aprendizagem foi variável. Na Escola Projeto Âncora, isso acontece de forma contrária: a aprendizagem é fixada e o tempo varia. Não existe a opção de não aprender, por isso cada estudante possui o tempo que for necessário para estudar qualquer tema. Por esse motivo, a Escola pode ser definida como um modelo de práticas educacionais inovadoras. São inúmeros os dispositivos que comprovam essa afirmação e que permitem que a aprendizagem caminhe de forma responsável: assembleias gerais, rodas de reflexão, grupos de responsabilidade, reuniões, planejamentos quinzenais, roteiros de aprendizagem, entre outros. Entretanto, não são apenas esses dispositivos que conferem ao Âncora um ambiente que rompe com práticas educacionais costumeiras. Em primeiro lugar, há as relações horizontais entre estudantes, pais e professores, sem esquecer a responsabilidade dos adultos em oferecer condições para que os imaturos enfrentem as suas próprias ignorâncias. Em segundo lugar, a concepção e utilização do espaço escolar como um espaço público, onde todos os acontecimentos do cotidiano escolar são levados ao entendimento de todos, que são requisitados a se responsabilizar por tudo. 
Creio que as experiências vividas em campo e o contato com a literatura específica foram suficientes para responder ao que apresentei como problema desta pesquisa: quais são os fatores que distinguem as práticas de inovação educacional das que são costumeiras em educação escolar? Concluo que a hipótese levantada inicialmente é verdadeira; que, dentre os fatores que distinguem as práticas educacionais inovadoras das práticas costumeiras, são preponderantes: a organização do trabalho pedagógico e as relações pessoais estabelecidas no cotidiano escolar. Com os resultados das análises sobre a organização do trabalho pedagógico, encontrei diferenças entre aquilo que se faz no Âncora e aquilo que é praticado comumente em outras escolas.

Essa diferença reside principalmente em aspectos como: dispositivos de ensinoaprendizagem voltados para o interesse dos indivíduos, utilização do espaço escolar segundo os objetivos da própria instituição, elaboração colaborativa dos documentos pedagógicos, avaliação baseada em competências atitudinais, concepção multirreferencial das finalidades educativas, formação contínua do corpo docente no próprio ambiente escolar e a posição central ocupada pelos estudantes no processo de aprendizagem. No que diz respeito às relações pessoais no cotidiano escolar, encontrei entre os seus integrantes: diferentes capacidades de comunicação, atividades que estimulam a cooperação em detrimento do individualismo, maior grau de autonomia para adoção de inovações, aptidão consolidada para a resolução de conflitos, ações baseadas nos interesses da comunidade local, diferentes dispositivos para estimular a participação e a colaboração de todos na formulação das decisões institucionais.

Dentre os principais fatores apontados por este trabalho que configuram a educação escolar costumeira, estão: 1) organização do trabalho pedagógico centrado no ensino; 2) confinamento das atividades educativas e dos agentes educativos dentro de um prédio escolar; 3) relacionamento com as famílias de maneira individual, formal e momentânea; 4) tentativas de melhorar práticas educacionais que são insignificantes para o processo de aprendizagem e para as condições atuais de vida dos envolvidos; 5) distanciamento da produção de saberes importantes às necessidades mais vivas dos indivíduos que fazem partem da vida escolar; 6) avaliação com foco restrito aos estudantes e que se pauta por uma escala de valores numéricos e no princípio da comprovação daquilo que foi ensinado por um educador. Em resumo, são práticas que se preocupam exclusivamente em organizar o trabalho pedagógico na direção de uma transmissão de saberes considerados indispensáveis e legítimos, embora sejam dissociados das exigências mais cruciais dos diferentes grupos sociais. 
Estudos futuros precisam ser desenvolvidos com outras escolas para avaliar a generalização do caso relatado neste trabalho. No entanto, a junção dos elementos observados em campo possibilitou uma análise efetiva dos traços distintivos entre as práticas educacionais inovadoras e as práticas educacionais costumeiras em educação escolar. Contudo, ainda há um vasto campo a ser descoberto, que envolve outras dimensões da inovação em educação escolar, como: por que se inova, de que forma se inova, o que se inova e quem inova. Por duas razões procurei limitar a análise da inovação em termos pedagógicos e aos fatores mais intimamente ligados a essa prática. A primeira diz respeito a minha própria atuação profissional relacionada, de modo predominante, à vivência da situação escolar. A segunda razão tem a ver com a constatação da grande quantidade de "inovações" ou, melhor dizendo, de "novidades" que as instituições escolares almejam introduzir em suas práticas educativas.

Procurei me distanciar também da confusão habitual em considerar a inovação como sinônimo de mudança e reforma educacional. Embora sejam conceitos que surgem interligados, definem realidades diferentes. Dessa forma, adotei a inovação como sendo a alteração de práticas educacionais costumeiras em um determinado grupo social. Inovação essa que nada tem a ver com a modificação de propostas curriculares e, muito menos, com a acepção de algo original ou positivo a priori. Nego essa acepção de original porque, por exemplo, um determinado professor de geografia que se concentra em educação ambiental a partir de atividades de campo nas comunidades em que vivem seus estudantes não estará, por esse motivo, realizando nada de original, porque isso pode ocorrer em outras escolas ou pode ter ocorrido em outros momentos históricos. Mas, se esse mesmo professor praticar a mesma ação em uma escola onde a prática costumeira é a de encarceramento das crianças, então, ele estará inovando. Nego também a acepção positiva de antemão do conceito de inovação, porque um professor pode simplesmente incentivar que os estudantes realizem uma exposição de suásticas pela escola como forma de comemoração do nazismo. Será uma prática inovadora se houver diferença com os costumes anteriores da instituição escolar, porém definitivamente não se trata de uma prática positiva. Logo, inovar não pode ser entendido irrestritamente como algo bom.

Espero ter contribuído, com esta investigação, para uma compreensão melhor da lógica a partir da qual se situam os principais agentes que atuam na educação escolar. Este trabalho consistiu-se em um esforço para avançar na direção do difícil e penoso terreno do diálogo entre as diferentes concepções das finalidades educativas. Difícil, pois o nosso sistema educacional ainda se preocupa em preparar as crianças para uma realidade que é vista como única e 
inequívoca. Penoso, pois seu objetivo principal ainda é transmitir às pessoas um conhecimento que lhes falta. No entanto, esse propósito está se tornando cada vez mais supérfluo, conforme se consolida a chegada de novas tecnologias que permitem o acesso à informação de modo instantâneo. Sem que se supere esse costume, estaremos limitados a uma perspectiva que despreza as práticas inovadoras em educação e que se mantém indiferente aos problemas mais vivos dos diferentes grupos que compõem a sociedade. Assim, a preocupação primordial de qualquer espaço educativo deveria ser com o desenvolvimento das crianças, onde suas escolhas fossem estimuladas e respeitadas e suas habilidades fossem concebidas sob a ideia de uma realidade multifacetada e um futuro cheio de incertezas. 


\section{REFERÊNCIAS ${ }^{16}$}

AGUERRONDO, Inés. La innovación educativa en América Latina: balance de cuatro décadas. Perspectivas, Genebra, v. 22, n. 83, p. 379-394, out. 1992. Disponível em: <https://goo.gl/avdZNE>. Acesso em: 9 out. 2017.

ALMEIDA, Sheyla Gomes de. Projeto Âncora: uma perspectiva de educação para a integralidade humana. 2017. 235 f. Dissertação (Mestrado em Educação) - Faculdade de Educação, Universidade de Brasília, Brasília. 2017.

ANDRÉ, Marli Eliza Dalmazo Afonso de. Estudo de caso em pesquisa e avaliação educacional. Brasília: Líber Livro Editora, 2005.

AZANHA, José Mário Pires. Uma ideia de pesquisa educacional. São Paulo: Edusp, 1992.

BUZATO, Marcelo El Khouri. Cultura digital e apropriação ascendente: apontamentos para uma educação 2.0. Educação em Revista, Belo Horizonte, v. 26, n. 3, p. 283-304, dez. 2010. Disponível em: <https://goo.gl/gdhdfE >. Acesso em: 30 jan. 2018.

CÂNDIDO, Antônio. A estrutura da escola. In: PEREIRA, Luiz; FORACCHI, Marialice Mercani (Org.). Educação e sociedade: leituras de sociologia da educação. São Paulo: Nacional, 1964. p. 107-128.

CARBONELL, Jaime. A aventura de inovar: a mudança na escola. Porto Alegre: Artmed, 2002.

CARRIER, Nathalie. How educational ideas catch on: the promotion of popular education innovations and the role of evidence. Educational Research, Londres, v. 59, n. 2, p. 228-240, jun. 2017. Disponível em: <https://goo.gl/twwfjn>. Acesso em: 30 jan. 2018.

DE ROSSI, Vera Lúcia Sabongi. Mudança com máscaras de inovação. Educação e Sociedade, Campinas, v. 26, n. 92, p. 935-957, out. 2005. Disponível em: <http://www.scielo.br/pdf/es/v26n92/v26n92a11.pdf>. Acesso em: 27 out. 2017.

DEBEAUVAIS, Michel. The popularity of the idea of innovation: a tentative interpretation of the texts. Prospects, Genebra, v. 4, n. 4, p. 494-502, 1974. Disponível em: <https://eric.ed.gov/?id=EJ113360>. Acesso em: 22 out. 2017. 
DEMO, Pedro. Rupturas urgentes em educação. Ensaio: avaliação e políticas públicas em educação, Rio de Janeiro, v. 18, n. 69, p. 861-872, out./dez. 2010. Disponível em: <http://www.scielo.br/pdf/ensaio/v18n69/v18n69a11.pdf>. Acesso em: 1 fev. 2018.

DÍAZ-BARRIGA ARCEO, Frida. Los profesores ante las innovaciones curriculares. Revista Iberoamericana de Educación Superior, Cidade do México, v. 1, n. 1, p. 37-57, 2010. Disponível em: <https://ries.universia.net/article/viewFile/32/91>. Acesso em: 1 fev. 2018.

Reformas curriculares y cambio sistémico: una articulación ausente pero necesaria para la innovación. Revista Iberoamericana de Educación Superior, Cidade do México, v. 3, n. 7, p. 23-40, 2012. Disponível em: <https://ries.universia.net/article/view/80/266>. Acesso em: 1 fev. 2018.

FERNANDES, Preciosa Teixeira. Inovações curriculares: o ponto de vista de gestores de escolas do ensino básico em Portugal. Educação em Revista, Belo Horizonte, v. 27, n. 1, p. 181-210, abr. 2011. Disponível em: 〈http://www.scielo.br/pdf/edur/v27n1/v27n1a09.pdf>. Acesso em: 1 fev. 2018.

FREIRE, Paulo. Educação e mudança. Rio de Janeiro: Paz e Terra, 2011.

FULLAN, Michael. Overview of the innovative process and the user. Interchange, Ontário, v. 3, n. 2, p. 1-46, jun. 1972. Disponível em: <https://link-springercom.ez67.periodicos.capes.gov.br/journal/10780>. Acesso em: 21 out. 2017.

The new meaning of educational change. New York: Teachers College Press, 1982.

GHANEM, Elie George Guimarães. Que avaliação vale na educação escolar? In: LUCE, Maria Beatriz; MEDEIROS, Isabel Letícia Pedroso de (Orgs.). Gestão escolar democrática: concepções e vivências. Porto Alegre: UFRGS, 2006. p. 157-160.

. A educação na mudança social: lugar central, lugar secundário e lugar nenhum.

Educar em Revista, Curitiba, v. 28, n. 45, p. 213-229, jul./set. 2012a. Disponível em: <https://goo.gl/LU4bGW>. Acesso em: 22 out. 2017.

Inovação educacional em pequeno município: o caso Fundação Casa Grande (Nova Olinda, CE, Brasil). Educação em Revista, Belo Horizonte, v. 21, n. 3, p. 123-124, set. 2012b. Disponível em: 〈http://www.scielo.br/pdf/edur/v28n3/a05v28n03.pdf>. Acesso em: 14 dez. 2016. 
Inovação em escolas públicas de nível básico: o caso Redes da Maré (Rio de Janeiro, RJ). Educação e Sociedade, Campinas, v. 34, n. 123, p. 425-440, jun. 2013a. Disponível em: <https://dx.doi.org/10.1590/S0101-73302013000200006>. Acesso em: 29 ago. 2017.

. Inovação em educação ambiental na cidade e na floresta: o caso Oela. Cadernos de Pesquisa, São Paulo, v. 43, n. 150, p. 1004-1025, dez. 2013b. Disponível em: <http://www.producao.usp.br/handle/BDPI/44523>. Acesso em: 29 ago. 2017.

GOLDBERG, Maria Amélia Azevedo; FRANCO, Maria Laura Puglisi Barbosa. Inovação educacional: um projeto controlado por avaliação e pesquisa. São Paulo: Cortez \& Moraes / Fundação Carlos Chagas, 1980.

HARE, William. The concept of innovation in education. Educational Theory, Illinois, v. 28, n. 1, p. 68-74, 1978. Disponível em: 〈https://goo.gl/u58RTz>. Acesso em: 08 fev. 2018.

HAVELOCK, Ronald; HUBERMAN, Michael. Solving educational problems: the theory and reality of innovation in developing countries. Paris: Unesco, 1977.

HECHT, Yaacov. Educação democrática: o começo de uma história. Belo Horizonte: Autêntica, 2016.

HOFMAN, Roelande; BOOM, Jan de; MEEUWISSE, Marieke; HOFMAN, Adrian. Educational innovation, quality, and effects: an exploration of innovations and their effects in secondary education. Educational Policy, Califórnia, v. 27, n. 6, p. 843-866, out. 2012. Disponível em: <https://doi.org/10.1177/0895904811429288>. Acesso em: 16 out. 2017.

HUBERMAN, Michael. Comment s'opèrent les changements en éducation: contribution à l'étude de l'innovation. Paris: Unesco, 1973.

IBGE. Instituto Brasileiro de Geografia e Estatística. IDH. 2019. Disponível em: $<$ https://cidades.ibge.gov.br/>. Acesso em: 24 abr. 2019.

INEP. Instituto Nacional de Estudos e Pesquisas. Censo escolar. 2019. Disponível em: <http://portal.inep.gov.br/censo-escolar>. Acesso em: 24 abr. 2019.

LEAL-SOTO, Francisco; HERNÁNDEZ, Mario Albornoz; PARADA, Maria Isabel Rojas. Liderazgo directivo y condiciones para la innovación en escuelas chilenas: el que nada hace, nada teme. Estudios pedagógicos, Valdivia, v. 42, n. 2, p. 193-205, 2016. Disponível em: <https://goo.gl/cCRsnB> Acesso em: 8 fev. 2018. 
LIMA, Lauro de Oliveira. Os mecanismos da liberdade: microssociologia. São Paulo: Polis, 1980.

MACÍAS, Arturo Barraza. Una conceptualización comprehensiva de la innovación educativa. Innovación educativa, Cidade do México, v. 5, n. 28, p. 19-31, set./out. 2005. Disponível em: <http://www.redalyc.org/articulo.oa?id=179421470003>. Acesso em: 21 out. 2017.

MACLEAN, Rupert. Innovaciones y reformas escolares en los países en desarollo de Asia. Perspectivas, Genebra, v. 22, n. 83, p. 395-408, out. 1992. Disponível em: <https://goo.gl/avdZNE >. Acesso em: 9 out. 2017.

MARCELO, Carlos. Las tecnologías para la innovación y la práctica docente. Revista Brasileira de Educação, Rio de Janeiro, v. 18, n. 52, p. 25-47, 2013. Disponível em: <www.scielo.br/pdf/rbedu/v18n52/03.pdf>. Acesso em: 5 mar. 2018.

MERRIAM, Sharan. Qualitative research and case study applications in education. San Francisco: Jossey-Bass, 1998.

MESSINA, Graciela. Mudança e inovação educacional: notas para reflexão. Cadernos de Pesquisa, São Paulo, n. 114, p. 225-233, nov. 2001. Disponível em:

<http://www.scielo.br/pdf/cp/n114/a10n114.pdf>. Acesso em: 29 ago. 2017.

MITRULIS, Eleny. Ensaios de inovação no ensino médio. Cadernos de Pesquisa, São Paulo, n.116, p. 217-244, jul. 2002. Disponível em: <https://goo.gl/PfwTrh>. Acesso em: 22 out. 2017.

MONTEIRO, Letícia Portieri; SMOLE, Kátia Stocco. Um caminho para atender às diferenças na escola. Educação e Pesquisa, São Paulo, v. 36, n. 1, p. 357-371, jan./abr. 2010.

Disponível em: <https://goo.gl/SzZXMx>. Acesso em: 12 mar. 2018.

MOREIRA, Adelson Fernandes. Basta implementar inovações nos sistemas educativos? Educação e Pesquisa, São Paulo, v. 25, n. 1, p. 131-145, jan./jun. 1999. Disponível em: <http://www.scielo.br/pdf/ep/v25n1/v25n1a10.pdf>. Acesso em: 12 mar. 2018.

NEILL, Alexander Sutherland. Liberdade sem medo. São Paulo: Ibrasa, 1970. 19ed.

NOGARO, Arnaldo; BATTESTIN, Claúdia. Sentido e contornos da inovação na educação. Holos, Natal, v. 2, p. 357-372, abr. 2016. Disponível em: <http://www2.ifrn.edu.br/ojs/index.php/HOLOS/article/view/3097>. Acesso em: 16 out. 2017. 
PACHECO, José. Pequeno dicionário de absurdos em educação. Porto Alegre: Artmed, 2009.

PROJETO ÂNCORA. Planejamento estratégico. Cotia, 1998.

Carta mensal junho. Cotia, 2003.

Carta mensal setembro. Cotia, 2009.

Carta mensal junho. Cotia, 2011.

Carta de princípios. Cotia, 2012.

Carta mensal abril. Cotia, 2013.

QUEVEDO, Thelmelisa Lencione. Escola Projeto Âncora: gestação, nascimento e desenvolvimento. 2014. 218 f. Dissertação (Mestrado em Educação) - Faculdade de Educação, Universidade de São Paulo, São Paulo, 2014.

SILVA, Josineide Teotonia da. Escola Projeto Âncora: um novo jeito de fazer a educação. Revista Administração Educacional, Recife, v.9, n.1, p. 147-170, jan-jun. 2018. Disponível em: <https://periodicos.ufpe.br/revistas/ADED/article/download/237527/29693>. Acesso em: 8 jun. 2019.

SPINK, Peter Kevin. O pesquisador conversador no cotidiano. Psicologia e Sociedade, v. 20, p. 70-77, 2008. Número especial. Disponível em:

<http://www.scielo.br/pdf/psoc/v20nspe/v20nspea10.pdf>. Acesso em: 20 jan. 2017.

STAKE, Robert. The art of case study research. Califórnia: Sage, 1995.

THURLER, Monica Gather. Inovar no interior da escola. Porto Alegre: Artmed, 2001.

TORRES, R. M. Reformadores y docentes: el cambio educativo atrapado entre dos logicas. In: CÁRDENAS, L.; RODRIGUEZ CÉSPEDES, A.; TORRES, R. M. El maestro, protagonista del cambio educativo. Bogotá: Convenio Andrés Bello; Magisterio Nacional, 2000. p. 161-312. 
TOURAINE, Alain. A escola do sujeito. In: Poderemos viver juntos?: iguais e diferentes. Petrópolis: Vozes, 1999. p. 317-328.

VEIGA, Ilma Passos Alencastro. Inovações e projeto político-pedagógico: uma relação regulatória ou emancipatória?. Cadernos CEDES, Campinas, v. 23, n. 61, p. 267-281, dez. 2003. Disponível em: <https://goo.gl/xjkems>. Acesso em: 9 out. 2017.

YIN, Robert. Case study Research: design and methods. Califórnia: Sage, 2014. 